\title{
CIUTAT I PODER EN EL FEUDALISME DECLINANT A LA CATALUNYA BAIXMEDIEVAL (DIFERENCIACIÓ SOCIAL I DISTRIBUCIÓ SOCIAL DE L'ESPAI URBÀ A Cervera, 1340-1382)'
}

\author{
JAUME RIBALTA I HARO \\ MAX TURULl I RUBiNAT
}

\begin{abstract}
SUMARI
I. Introducció: ciutat i feudalisme. 1. El tema: la ciutat medieval en la transició: canvi economic i èlit social. 2. La font: el Manifest cerverí. 3. La metodologia: estadística històrica. - II. Els condicionants històrics: població i divisió de l'espai a Cervera al segle XIV. - III. Diferenciació social i formació d'una èlit dirigent: desigualtat social i patriciat urbà emergent. 1. La riquesa social de Cervera al segle XIV. Una aproximació general. 2. La distribució de la riquesa: la desigualtat social i el seu grau. 3. La composició de la riquesa: l'estructura sòcio-econòmica. 4. La formació d'una èlit dirigent: el patriciat emergent com a oligarquia i grup de poder urbà. - IV. La producció social de l'espai urbà medieval: prestigi social i segregació sòcio-espacial. l. La segregació sócio-espacial: la configuració del quarter de la Plaça com a centre-vila. 2. El prestigi social del centre (la Plaça): des del comerş a les professions liberals. - V. Conclusió. Diferenciació social i distribució social de l'espai a la Cervera baixmedieval. Patriciat urbà i segregació sòcio-espacial.
\end{abstract}

\section{INTRODUCCIÓ: CIUTAT I FEUDALISME}

Que los pahers de Cervera puxen tatxar los veyns de la dita vila aprés que ab sagrament hauran manifestat sos bens per mes bens que no hauran manifestats".

1 El present treball s'inscriu en el projecte d'investigació La creación del derecho en Cataluña dirigit per Aquilino Iglesia Ferreirós i finançat per la CICYT PB 90-0474. Els mapes, figures i gràfics citats a les notes es troben en apèndix al final del treball.

'AHCC, Pergamins s/n; LP 1272 setembre 3, fol. 7 r-7 v. 
Rodney Hilton reclamava, en fer balanç de l'estat de la historiografia sobre l'origen de les ciutats en el debat de la transició del feudalisme al capitalisme, la necessitat d'endegar recerques sobre l'especialització ocupacional en la ciutat medieval, és a dir, de la seva estructura sòcio-econòmica '. Malgrat importants contribucions científiques de la nostra historiografia sobre les relacions campciutat en la transició, aquella demanda de Hilton -reiterada per obra dels traductors-, lluny d'haver estat totalment satisfeta, roman encara avui en dia ben vigent i se'ns revela com a base empírica essencial i imprescindible en l'estudi històric de la ciutat medieval.

No hi ha dubte de la importància central de l'estudi de la relació campciutat en la transició al capitalisme i això va quedar palès en les diferents contribucions teòriques al debat historiogràfic sobre el problema dels orígens del capitalisme . Però, des que l'estudi de la història urbana va obrir-se a diferents disciplines, s'han desenvolupat, com a mínim, dues visions alternatives sobre la ciutat: des de la sociologia, una concepció abstracta l'entén com un ens aillat de la resta de societat (allunyada dels principis de les societats en les quals està immergida) i situa la societat medieval en el pol tradicional de la seva classificació (la pre-industrial o tradicional i la industrial) i, des de la història, caldria situar aquella concepció-generalment compartida per totes les contribucions teòriques al debat de la transició- que la veu com a producte històricament condicionat d'una societat i de les seves forces i relacions socials, tant de les internes de la mateixa ciutat com les d'aquesta respecte del conjunt social sencer'.

'Rodncy HILTON, Introducción, in Rodney HILTON (ed), La transición del feudalismo al capitalismo: Barcelona, 1987', pp. 7-39, especialment p. 22. [Reedició sense nota final a: Rodney HILTON, El feudalismo y los orígenes del capitalismo in Rodney HiLTON, Conflicto de clases y crisis del feudalismo; Barcelona, 1988, pp. 180-203, especialment pp. 191-192]. Pel desenvolupament més extens d'aquella inquietud inicial, vid. Rodney HILTON, Les ciutats medievals, Barcelona, 1989.

4 John MrRrington, Ciudad y campo en la transición al capitalismo, in Rodncy Hil.TON (ed), La transición del feudalismo, pp. 238-276, especialment p. 238. Per una revisió, des d'una perspectiva sociològica, de la problemàtica de l'espai urbà en la transició, vid. Albert García ESPUChE et Manuel GuÁrdia I BASSOLS, "Transición i ciutat: les transformacions de l'estructura de l'espai, "Manuscrits. Revista d'Història Moderna", 4-5 (1987), pp. 143-170.

'Per una visió general de l'estudi sobre la ciutat, vid. David HerL.IHY, Urbanización y cambio social in Jerzy TOPOLSKI, Carlo M. CIPOLLA et alii, Historia económica. Nuevos enfoques y nuevos problemas. Comunicaciones al Séptimo Congreso Internacional de Historia Económica, Barcelona, 1978, pp. 111-143. Com a exposicions de la visió sociologica, vid. Lewis MUMFORD, La ciudad en la bistoria (sus origenes, transformaciones y perspectivas), Buenos Aires, 1966, i, seguint els plantejaments de Max Weber, Gideon SJOBERG, Le cità dei padri. Re, pastori, ladri e prostitute nelle civiltà preindustriali, Milano, 1980. Per un resum crític de la visió historica, vid. Rodney HıLTON, Les ciutats medievals, pp. 9-10. 
A partir d'aquesta darrera visió, situar la ciutat i definir-ne el seu caràcter en la transició significa haver de considerar de la mateixa manera dos problemes diferents però interconnectats: primer, caldrà determinar la posició estructural de la ciutat en el feudalisme $i$, segon, veure com ciutat i feudalisme van interaccionar en la dinàmica de transformació de la transició i com en van resultar afectats.

A ningú escapa que plantejar-nos aquests problemes i en la generalitat d'aquests termes, des de l'àmbit $\mathrm{i}$ abast reduît d'un treball de microhistòria com aquest, resulta desproporcionat i arriscat si no es té en compte l'objectiu principal que ens guiava de defugir i superar una determinada concepció de la història local: la rellevància teòrica dels dos problemes apuntats i la pràctica metodològicament rigurosa d'una història d'àmbits localitzats exigeixen el seu tractament. Però, donat que la manca de plantejaments teòrics generals de part de la historiografia medievalista catalana sobre la qüestió feia impossible el nostre objectiu, calia assumir -amb tots els riscs i desproporcions possibles $\mathrm{i}$ imaginables- la tasca d'omplir aquesta llacuna d'alguna manera. Sense altres punts de referència més propers, ens hem vist obligats a recórrer a la recuperació $i$, en certa mesura, adaptació dels plantejaments teòrics desenvolupats en la historiografia anglo-saxona, especialment de Hilton i Nell. Evidentment que el transplantament -encara que sigui amb adaptacions prèvies al medi- va sempre acompanyat d'un elevat grau de risc a errar i, per tant, cal advertir que els nostres plantejaments generals són més aviat propostes -punts de referència-sobre les quals caldrà retornar, recapitular, revisar i esmenar a la llum i a partir de l'estudi empíric de força més casos històrics; però, com preteníem posar de manifest, l'establiment d'un cert o qualsevol marc teòric -encara que fós tan precari com el que proposem- era una tasca imprescindible $\mathrm{i}$ indefugible.

Definir el lloc estructural de la ciutat en el feudalisme significa determinar si aquesta fou un factor de dissolució o bé típicament integrat en el sistema: les ciutats medievals, van ésser elements plenament integrats i conformistes dins del sistema feudal o, més aviat, van ésser cèl-lules antagòniques i cancerígenes -portadores del capitalisme- dins del feudalisme? De l'acceptació com a vàlid de cadascun dels pols d'acquesta disjuntiva, s'han desenvolupat dues teories diferents per contextualitzar la ciutat medieval en el feudalisme, per definir-ne la seva naturalesa social: d'una banda, la teoria -que podem identificar com a tradicional-considerava la ciutat com un ens - per essència- totalment estrany $i$ antagònic al conjunt del sistema social feudal dins del qual es desenvolupava $i$ creixia com a cèl-lula cancerígena; l'antagonisme era tan marcat que calia atribuir la seva aparició a una creació des de fora per uns comerciants (els anomenats burgesos) desarrelats i desclassats que tractaven d'introduir mercaderies de luxe -procedents del comerç a llarga distància- $\mathrm{i}$ el desig de beneficis 
monetaris en el teixit de l'economia estàtica i autàrquica de l'Europa feudal; " $i$, d'una altra, la visió alternativa que pretén, en canvi, veure la ciutat com a totalment integrada dins la societat agrària feudal; així, la ciutat seria una part del sistema feudal $i$ es trobaria inserida en les seves contradiccions, però sense ésser-ne el principi de contradicció '.

Hilton, en el seu estudi de les ciutats angleses, a part d'una interessant classificació bipolar de la xarxa urbana a l'entorn de dos grans tipus de ciutats (uns petits centres urbans on la pagesia monetaritzava el seu excedent econòmic $i$ uns de grans on els feudals consumien el resultat de la seva apropiació de l'excedent pagès) ${ }^{8}$, plantejava i argumentava -sense oblidar les diferències que

' Henri Pirenne, Las ciudades de la Edad Media, Madrid, 1987', pp. 139-145, especialment p. 144.

7 Rodney Hilton, Las ciudades en la sociedad feudal inglesa in Rodney HiLTON, Conflicto de clases y crisis del feudalismo, Barcelona, 1988, pp. 106-122, especialment p. 112. HILTON va rependre les idees exposades en l'article anterior $i$ en va fer un desenvolupament de les mateixes a partir de l'estudi comparatiu de les ciutats angleses $\mathrm{i}$ franceses (Rodney HILTON, Les ciutats medievals, pp. 25-41). El plantejament que tot seguit oferim és essencialment deutor d'aquests treballs; encara que cal advertir que, si bé manca per Catalunya una exposició de conjunt com la citada de Hilton, hem considerat com a vàlids els seus punts de partida per bé que caldrà fer-hi, ara necessàriament des d'un punt de vista teòric, algunes adaptacions específiques $i$ pròpies de la nostra formació social $i$, posteriorment $i$ a partir de l'anàlisi històrica d'altres ciutats, segurament revisar i reconsiderar aquests plantejaments apriorístics.

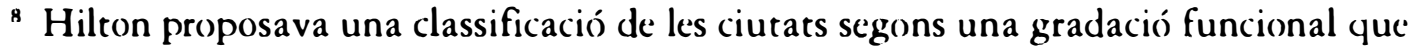
podria aproximar-se gràficament a una piràmide on la base estaria formada per un conjunt prou gran format per petits nuclis urbans i la cúspide, en canvi, per un altre conjunt més restringit de centres urbans més grans. La diferenciació de funcions s'articularia bàsicament a l'entorn del seu paper econòmic: les ciutats de la base actuarien principalment de centres on la pagesia monetaritzaria el seu excedent econòmic per després esmerçar el seu resultat entre la compra de les mercaderies manufacturades produïdes en la mateixa ciutat i el lliurament de la part més substancial com a ingrés de la feudalitat en pagament dels sceus drets senyorials; en canvi, les grans ciutats de la cúspide actuarien d'àmbit on aquesta feudalitat consumiria l'excedent rebut en la compra de mercaderies de luxe, d'aquelles que els petits nuclis propers als seus dominis serien incapaços d'abastir-la (Rodney HILTON, Las ciudades en la sociedad feudal inglesa; pp. 112-113). La relació causal que vincula grandària urbana amb especialització funcional s'havia abordat, respecte la ciutat medieval, sobretot a partir de constatar l'abast territorial del mercat ciutadà (ciutats amb mercat local, comarcal, regional o transregional) o bé la funció econòmica principal de la ciutat (ciutats manufactureres o centres d’administració secular o eclesiàstica) (A.B. HIBBERT, «La política económica de las ciudades" in M.M. POSTAN, E.E. RICH et Edward MILLER, eds. Historia económica de Europa. III. Organización y política económica en la Edad Media; Madrid, 1972, pp. 195-289, especialment pp. 197-198, 225); però, més recentment, s'ha considerat la seva grandària com a factor determinant en la seva especialització funcional (la grandària determinaria que, en les ciutats petites, hi hagués com a component social dominant la pagesia i, en canvi i a mesura que creixia la seva quantitat de població, prengués un paper principal la manufactu- 
separaven ambdós àmbits- la seva tesi segons la qual societat i economia urbanes presentaven en general unes coordenades bàsiques comunes amb el món rural feudal per finalment ocupar-se del tret diferenciador més problemàtic i essencial: el caràcter polític de l'oligarquia urbana.

Els elements que permetien a Hilton establir l'analogia entre món urbà i món rural en el feudalisme són bàsicament que, tant a ciutat com a pagès, les estructures socials $\mathrm{i}$ econòmiques es fonamentaven en la família com a unitat de producció i distribució (l'obrador menestral i/o la petita botiga al detall o una combinació d'ambdues eren les bases del món urbà); semblantment, equiparava el cim social urbà -compost per una èlit bàsicament de comerciants capitalistes- amb els senyors dels grans dominis feudals. Si bé, en principi, hom podria dubtar de l'homogeneïtat d'interessos entre ambdós col·lectius (els ingressos dels terratinents feudals provenien de l'apropiació del treball excedent de la pagesia i, en canvi, els dels comerciants capitalistes depenien de l'acompliment d'una funció d'intermediari comercial). El fet que els grans beneficis dels comerciants fossin el resultat de l'abastament de béns de luxe a les corts reials o aristocràtiques $i$ de préstecs -sobretot per a finançar l'activitat militar- a les mateixes corts, li permet afirmar que indirectament els beneficis dels comerciants provenien també $\mathrm{i}$ igualment de l'excedent pagès perquè els seus rendiments anaven directament vinculats als ingressos disponibles pels terratinents $i$, per tant, es veien afectats pels canvis en l'equilibri de poder entre senyors i pagesos. Respecte als elements pròpiament urbans com artesanat i gremis, planteja la situació de l'artesà com la d'una empresa familiar el circuit econòmic de la qual es configura a partir dels guanys que obté de l'explotació d'un treball remunerat (jornalers assalariats) i no-remunerat (aprenents) $i$ on part dels seus guanys són apropiats com a benefici pel comerciant-intermediari; a partir d'aquesta visió anterior, els gremis artesanals actuaven, en les grans ciutats, com a estructures intermèdies entre artesans-petits comerciants $i$ govern urbà que, sovint, s'identificava amb l'èlit urbana ".

Hilton posava l'accent sobre aquesta darrera característica perquè és el cor mateix del paper de la ciutat en la societat feudal: aquesta èlit de mercaders capitalistes exercien, a més de la dominació social i econòmica i com un derivat seu, una dominació política directa? o bé, per exemple, es servien de testaferros -d'homes de palla l'ascendència sobre els quals restava garantida per llur dominació sòcio-econòmica- per a la defensa política dels seus interessos? En principi, hom podria pensar que, fins a cert punt, la dependència clientelar dels capitalistes mercantils respecte de l'aristocràcia rural i de la monarquia -com a

ra $\mathrm{i}$ els serveis, i com a indicador de la màxima grandària aparegués el comerç com a essencial) (Norman J.G. POUNDS, Historia económica de la Europa medieval, Barcelona, 1981, pp. 261-326, especialment pp. 297-298).

9 Rodney HiLTON, Las ciudades en la sociedad feudal inglesa, pp. 113-115. 
principals clients seus que eren- determinava la seva total subordinació als poders feudals; però, d'altra banda, sembla clar que aquests mateixos poders feudals van adonar-se aviat que la seva forma de dominació política era inapropiada a les ciutats, sobretot a les grans, i que els resultava menys productiva que atorgar-los alguns nivells d'autogovern a canvi d'algunes contraprestacions econòmiques ${ }^{10}$.

Què representava i com s'articulava el poder feudal en les ciutats de jurisdicció senyorial? Entre una munió de diversos drets senyorials (rendes sobre cases, obradors $\mathrm{i}$ botigues, drets sobre el traspàs de les tinences agràries $\mathrm{i}$ les herències, etc), segurament els que proporcionaven més grans i substanciosos ingressos eren els derivats del comerç i dels burgesos: sens dubte, ocupen un lloc principal les taxes pagades per les transaccions en el mercat pels noburgesos (lleudes i peatges), l'exercici de la jurisdicció també produïa una important renda en diner (diferents taxes i multes i defensa dels drets senyorials) i no menys significatiu resultava el cànon d'ingrés a la condició de ciutadà. Per tant, normalment el senyor i els burgesos ajustarien els seus interessos per tal de mantenir el monopoli del mercat per part d'aquests darrers $i$ el dret del senyor als ingressos de les taxes, encara que hi pogués haver friccions".

Si el predomini feudal era gairebé aclaparador a les petites ciutats de

11" Rodney Hilton, Las ciudades en la sociedad feudal inglesa, p. 115. Si bé aquest plantejament pot ser acceptable de forma genèrica, el fet d'encabir en un mateix sac totes les ciutats no deixa d'ésser una simplificació reductiva ja que un factor de la importància de la jurisdicció no pot ser, de cap manera, menyspreat a causa de les seves enormes repercussions en la forma d'entendre i gestionar internament aquest autogovern: les ciutats reials gaudien d'una total autonomia respecte de la feudalitat (encara que no hem d'oblidar que formar part de la jurisdicció reial significava que el rei era el senyor d'aquelles viles o ciutats) $i$, en elles, l'oligarquia urbana tenia les mans totalment lliures per exercir l'autogovern i, en canvi, existien ciutats normalment sota domini senyorial que, malgrat el seu desenvolupament econòmic, no havien aconseguit l'esmentada autonomia. L'autogovern pot ser facilment identificable amb la capacitat d'autoregular-se, pròpia de la universitas com a persona jurídica en el context jurídic del ius commune; per bé que l'existència d'universitas no pot identificar-se directament amb la independència del municipi, sinó intervenen autonomia i reconeixement del titular de la plenitudo potestatis. Sobre la importància de l'autonomia per definir aquest autogovern com a municipi, vid. Max TurUll I RUBINAT et Jaume RIBALTA I HARO, "De voluntate universitatis". La formació i l'expressió de la voluntat del municipi (Tärrega, 1214-1520), "Anuario de Estudios Medievales", 21 (1991), pp. 143-231. Seria intercssant poder esbrinar fins a quin punt existeix alguna relació entre grandària, funció de les ciutats (grans o petites) i la seva autonomia: una possible $\mathrm{i}$ interessant hipòtesi a considerar seria el fet que l'atorgament d'autonomia era un factor de creixement i desenvolupament, mentre que el lligam heterònom seria estroncador econòmicament pel continu drenatge econòmic de part de l'autoritat jurisdiccional.

"Rodney HiLTON, Las ciudades en la sociedad feudal inglesa, p. 116. 
mercat subjectes al seu domini, en quina mesura en quedaven excloses les grans ciutats privilegiades, és a dir, aquelles que restaven sota la jurisdicció reial? L'autonomia gaudida era prou completa com per separar de l'ordre feudal la burgesia com a entitat política? Van poder els burgesos desenvolupar dins d'aquest àmbit protegit les forces, els mitjans i les relacions de producció perquè arribessin a entrar en contradicció i finalment destruissin el feudalisme?

Des d'una lectura exclusivament sòcio-econòmica, el paper de la monarquia no es diferencia pas gaire del seu entorn feudal: les llibertats corporativociutadanes de la majoria de les grans ciutats van ser concedides per privilegis reials a canvi no sols d'una important suma global, sinó també del pagament d'algunes rendes periòdiques: encara que sigui forçant una mica els termes, la fiscalitat reial pot ser entesa -sense massa problemes- d'aquesta manera. Aquestes rendes poden ésser vistes com una compensació per les diverses quantitats que els oficials reials cobraven abans com a representants dels senyors de la ciutat ${ }^{12}$. La monarquia tolerava un sistema de tribunals ciutadans (juí de proboms), reminiscència de les atribucions que en matèria de justícia penal havia tingut el municipi, i que era tan diferent del sistema jurisdiccional de la corona com la jurisdicció privada dels senyors territorials, però sempre es reservava als tribunals reials les habitualment profitoses apel-lacions. De fet, sovint el dret aplicat a la ciutat, tret del particularisme de les ordinacions municipals que s'ocupaven de regular aspectes de policia urbana, tendia a motllurar-se o simplement s'identificava amb la legislació del rei i del regne vigent $\mathrm{i} / \mathrm{o}$ bé es mantenia ancorat en disposicions privilegiades -que sovint recollien costums anteriors- de marcat caràcter arcaîtzant en el segle XIV: aquest dret municipal era tan conservador en alguns casos $\mathrm{i}$ innocu en d'altres que gairebé no pot ser considerat com a força antifeudal; però, en qualsevol cas, la monarquia utilitzava els tribunals ciutadans en els seus aspectes polítics i administratius així com en la seva funció judicial. A part dels tribunals ciutadans primitivament indiferenciats es van desenvolupar no sols tribunals especialitzats sinó i sobretot consells de govern ". Ambdós van ésser usats per la

12 Sobre la xarxa d'oficials reials a Catalunya (veguers, batlles i corts) i sobre less seves atribucions com a representants o defensors dels interessos del monarca (recaptadors de drets $\mathrm{i}$ impostos sobretot), vid. Jesús LALINDE ABADÍA, La jurisdicción real inferior en Cataluña (corts, veguers, batlles), Barcelona, 1966, especialment pp. 83-89.

"La progressiva substitució en les seves funcions polítiques del Consell general de les viles catalanes pel Consell particular, on el poder polític i social de l'oligarquia ciutadana podia desenvolupar-se de forma més ampla i potent, sembla ésser una manifestació ben evident d'aquesta tendència apuntada (TURUI.I. I RUIBINAT et RIBAI.TA HARO, "De voluntate universitatis», pp. 143-231; Max TURUI.l. I RUBINAT et Jaume RIBAITA I HaRO, Entre la "universitas» $i$ el "Concilium Generale». El Consell General a Tàrrega (1.313-1.396) in "Urtx", 2 (Tàrrega, 1990), pp. 37-48). 
corona com a òrgans de control social: protegien els privilegis oligàrquics de les èlits capitalistes comercials dirigents front al descontentament polític dels grups mitjans i baixos de productors industrials, petits venedors i treballadors assalariats ${ }^{14}$.

Vistes en conjunt, tant les ciutats grans com les petites és evident que no poden ésser considerades com a illes no feudals enmig de mars feudals. $\mathrm{Ni}$ podem considerar els interessos socials i econòmics dels burgesos medievals com a oposats i en desenvolupament antagònic als interessos feudals de la classe terratinent $\mathrm{i}$ de la monarquia. Les èlits urbanes es trobaven, evidentment, sovint enfrontades als senyors feudals $\mathrm{i}$ als representants de la corona; però aquestes disputes eren menors i per aspectes de poca transcendència que no posaven mai en qüestió el fonament mateix del seu poder i dominació social. Cal veure l'economia urbana com una part del conjunt de l'economia feudalsenyorial. La urbanització, en el nivell de la petita ciutat de mercat, era la conseqüència necessària de la producció simple de mercaderies del pagès dins de l'estructura de la senyoria feudal i sotmesa a les seves exigències; en canvi, la urbanització de les grans ciutats era la conseqüència del consum de l'excedent agrari per la corona i l'aristocràcia, i dels beneficis de la funció d'intermediari dels capitalistes comercials grans, mitjans i petits.

\section{I.1. El tema: la ciutat medieval en la transició: canvi econòmic i èlit social}

Després de situada la posició estructural de la ciutat en el feudalisme, convé plantejar-nos com va afectar-la (quines repercussions socials i econòmiques) aquell procés general de canvi que anomenem transició o, si voleu i per evitar malentesos, la part inicial d'aquell procés que hom anomena la primera crisi general del feudalisme (segle XIV); per això ens caldrà, en primer lloc, tenir una visió clarificada -els esquemes són sovint simplificadors i reductors, però la seva virtualitat aclaridora és innegable- d'aquest procés per després $i$, en segon lloc, endinsar-nos en el problema de com en va resultar afectada la ciutat.

$\mathrm{Ha}$ esdevingut ja un tòpic afirmar que els segles XIV i XV representen, en l'evolució general del feudalisme europeu- occidental, una fase d'estancament i depressió econòmica, de crisi respecte a una fase anterior (segles XII-XIII) de fort creixement, sobretot agrícola. La ciutat va haver de respondre, com un element més d'aquesta societat, a aquesta nova situació econòmica general $i$, per això, el nostre centre d'interès (la ciutat) ens duu necessàriament a un altre

1. Rodney HILTON, Las ciudades en la sociedad feudal inglesa, pp. 117-118. 
problema: la transició del feudalisme al capitalisme i el debat entre causes externes i causes internes en la dissolució del feudalisme. Com cal considerar la ciutat? Com a producte de les forces exteriors que eren cridades a enderrocar el feudalisme? o bé el feudalisme duia en ell mateix els elements que l'havien de transformar?. Destriables a partir d'aquest esquema, s' han proposat tres teories diferents per tal d'explicar la transformació: dues que l'atribueixen a factors externs (la teoria del comerç" i la teoria de la població ") i una a factors interns (la teoria de la lluita de classes ").

1s La base argumental de la ja clàssica teoria del comers, en general obra d'Henri Pirenne (Henri Pirfnne, Historia económica y social de la Edad Media. México, 1983'1. Henri PIRENNe, Las ciudades de la Edad Media, Madrid, 1987'), considerava el comerş com a element motor de la transformació: la reanimació del comers a llarga distancia, iniciada poc abans del segle XI, va provocar l'expansió econommica occidental; l'esmentada recuperació comercial va enfortir l'economia, va estimular el desenvolupament urbà i va trencar els rígids límits de la senyoria dominical amb la seva economia autesuficient. En certa forma, Pirenne i els seus seguidors consideraven la ciutat com a producte d'aquesta força exterior: el comerç. En el debat de la transició, seguí inicialment aquesta línia explicativa Paul Sweezy (Paul M. SWEEZY, Critica in Rodney HIITON (ed), La transición del feudalismo al capitalismo, Barcelonal, 1987', pp. 43-77); però, més tard, suggerí una nova lectura del paper del comerş: la transformació del feudalisme no fou resultat del comers, sinó de l'impacte d'una economia avançada (el món àrab) sobre una d'endarrerida (l'Europa feudal occidental) (Paul Sw'EEZZY Contrarréplica in Rodney HILTON (ed), La transición del feudalismo. Pp. 142-1 52, especialment p. 147). Per una exposició actualitzada de les tesis pirennianes feta per un dels seus deixcbles, vid. H. VAN WIRVIEKI, El auge de las ciudades in M.M. POSTAN, E.L. RICH et Edward MILl.ER (eds), Historia económica de Europa. III. Organización y política económica en la Edad Media, Madrid, 1972, pp. 3-50, especialment pp. 48-50.

16 L'excessiva unilateralitat de la teoria del comerş en la seva defensa a ultrança dels factors externs en la transició (sobretot el comers) va provocar la seva revisió de part d'altres historiadors que han vist en el creixement demografic el factor principal que va aconduir al creixement economic i que va donar l'impuls decissiu a tot el desenvolupament (teoria de la població) i, en ayuest sentit, la teoria de la població, al només relativitzar i no qüestionar-se la importancia de la revitalització del comers, es configurà no tant com una alternativa a la teoria del comers, sinó com una teoria complementària, desenvolupada per tal de remeiar alguna de les seves limitacions (Michael M. PoS'IAN, lil comercio de la liuropa medievial: el Norte in M. M. Postran ce E. LE. RICH (eds), Historia economica de Europa. II. Eil comercio y la industria en la Edad Media, Madrid, 1967, pp. 157-325). La base argumental de lat tesi de Postan és una mena de neo-malthussianisme perque situa canvis demografics com a fonament de l'augment i desenvolupament del comers (Michael M. P(os'TAN, til comercio, pp. 207 i 274-278).

"Malgrat fer algunes aportacions significatives, ni la teoria del comers ni la de la població eren acceptables en el seu conjunt i formulació per a Maurice Dobb que intentà, a partir d'aprofitar-les però inserint-les en un marc teoric diferent com era el materialisme històric (en el qual es presenta com a principal motor del canvi social la lluita de classes), la seva reformulació i revisió veient com a causa principal i atribuint el protagonisme en el procés de canvi al caràcter dinàmic del mode de producció feudal: la lluita entre els senyors 
Evitant deliberadament reproduir de manera minuciosa els termes, d'altra banda força coneguts, d'aquell debat ja clàssic, ens remetem a les revisions de Brenner i Nell; cal fer especial incidència en la hipòtesi proposada per aquest darrer autor segons la qual, a partir de la crítica argumental de les explicacions de factor de les anteriors teories, cal situar -com a element central de la seva explicació per xarxa factorial i desllorigador de la polèmica- l'estudi de la composició de l'èlit sòcio-econòmica baixmedieval 't ${ }^{\text {. }}$ La importància d'aquest plantejament -que entronca de manera directa i específica amb la posició i les petjades pioneres de Hilton que seguim- és evident perquè, si hem anat defensant com a necessitat imprescindible l'estudi empíric del caràcter i naturalesa sòcio-econòmica d'aquesta èlit que domina i governa la ciutat, representa resituar-la com a tòpic central del debat sobre la transició. Determinar la naturalesa social i el paper desenvolupat per la ciutat en la primera crisi general del feudalisme passa, evidentment, pel coneixement del caràcter i naturalesa de l'estructura social de classes d'aquest corpus social que anomenem ciutat $\mathrm{i}$, en especial, de l'estudi de l'evolució històrica de la o les classes socials hegemòniques en la ciutat ".

feudals i els seus dependents per una porció més gran en la distribució de l'excedent va impulsar el progrés economic i va aconduir a una millora de l'estructura productiva fecudal. La dinànica del sistema feudal és, per tant, el factor impulsor del creixement de la producció de mercaderies i del procés d'urbanització (Maurice DOBB, Estudios sobre el desarrollo del capitalismo, Madrid, 1988", pp. 62-63 i 68).

is Per un balanç crític d'aquestes teories i intent de superar-les, vid. Robert BRINNER, Eistructura de clases agraria y desarrollo económico en la Europa preindustrial in T.H. AsToN et C.H.E. PHII.PIN (eds), El debate Brenner. Estructura de clases agraria y desarrollo económico en la Europa preindustrial. Barcelona, 1988, pp. $21-81$; per una interessant i crítica analisi de la transicio des de la teoria coconomica, és a dir, una anàlisi d'arguments més que no pas una reconstrucció de fets, eid. Edward J. Ni:L., Relaciones económicas en el declive del feudalismo: un examen de la interdependencia ecomoimica y del cambio social in Edward J. Nit.l., Historia y teoria económica, Barcelona, 1984, pp. 41-94.

10. Des de la pràctica de l'ofici d'historiador, el nostre treball neix com a resposta o, almenys, com a intent de respondre factualment al model tèoric proposat des de l'economia per Edward J. Nell (Edward J. Nel.L. Relaciones económicas, pp. 41-94); dit d'una alera manera, intentarem, a partir de l'estudi micro-historic d'un cas concret, verificar empíricatment el model de l'economista nord-americà. La historia economica és, potser, l'únic laboratori per excel-lència de la teoria economica (Alfons BARClio, Modelitzacióo economica a partir de dades bistòriques, "Recerques», 19 (1987), pp. 9-16, especialment p. 10) i, a més a més, l'ús d'un model ens atansa analogicament a l'experimentació de laboratori (Alfons BARCli.o et l.luís ARGEMí, Introducción in Edward J. Nitl., Historia y teoria económica, Barcelona, 1984, pp. 7-36, especialment p. 26). Però, quan, en història econòmica, es deixa de banda l'experimentació, només queda metodologicament l'obscrvació, la verificació cmpírica (Paul JANsSl: NS, Verificación empirica y verificación experimental en bistoria económiias, in Historia connomica: nuevos enfoumes y nuevos problemas. Comunicaciones al a Séptimo 
Al llarg del període de la història europea occidental -amb totes les desigualtats regionals de ritme que hom vulgui veure-hi, ja que parlem a nivell de tendències generals- que va des del segle XI fins el segle XV, va produir-se un canvi social important i essencial en la naturalesa i composició de l'èlit social hegemònica que representava el trànsit des d'una èlit homogènia i única formada pels senyors de la guerra (la metàfora resulta una mica reductiva i simplificadora, ja que a la noblesa feudal dels bellatores caldria afegir-hi els estrats alts dels oratores que, igualment, exercien de senyors feudals en els seus dominis) fins a una èlit social heterogènia i diferenciada formada per un conglomerat de comerciants i gremis d'artesans urbans".

En el segle XI, la posició políticament i econòmica dominant de la noblesa i clergat terratinent (els feudals o feudalitat, per entendre'ns) estava assegurada

Congreso Internacional de Historia Económican, Barcelona, 1981, pp. 60-70, especialment p. 60). Nell proposava, com a argument central per entendre les relacions conomicyues i el canvi social en el declivi del feudalisme, l'estudi de l'oligarquia conomica baixmedicval: segons ell, calia explicar el canvi de la natura i composició de l'èlit social curopea occidental entre els segles XII i XV (Edward J. NFil., Relaciones económicas, p. 62). Segons la seva lectura, l'explicació d'acuesta canvi tenia la seva causa bàsica en una sèric de desenvolupaments tecnoliggics, en part autoonoms, que van provocar un canvi en les relacions de dependència entre els diferents sectors ceconomics $i$, després, van afectar la relació entre poder economic i poder militar, alterant les relacions entre les classes que es fonamentaven en la possessió de mitjans de coerció, mitjans de producció i control del comerş (Eedward J. Nist.l., Relaciones economicas, pp. 68-69). Fn base a acpuests canvis tecnoliogics, distingia tres ctapes successives en aquest desenvolupament: primer, l'augment de la productivitat agrícola permetia l'abastiment de les ciutats i així, mentre el camp era autosuficient, les ciutats depenien del camp respecte l'oferta alimentària i el poder militar de la noblesa descansava en les capacitats productives del camp; segon, sorgeix una classe de mercaders que possecix el monopoli d'informació sobre les condicions de comers i que és capaç de crear i aprofitar les diferències de preu. La noblesa i, fins a cert punt, la pagesia, es fan dependents de les ciutats pel teixit de superior qualitat que producixen i les ciutats poden parcialment autoabastar-se i defendre's elles matcixes i, tercer, el camp es fa dependent en gran mesura de les ciutats que l'abasten d'una sèrie de béns, i la noblesa es fa dependent dels artesans urbans pels nous tipus d'armes i armadures produits. Es desenvolupa una artesania cualificada, la cual cosa implica que venedors i compradors es relacionin directament en el comers i aixi desplacin del seu llox d'intermediaris privilegiats als mercaders. Lil canvi en el caracter de la guerra crosiona el monopoli de la noblesa en relacio al poder militar (lidward J. NEil.l, Relaciones economicas, p. 69). No estaria de més recordar que l'argumentacio de Neil és abstracta i que les fases, que aqui es presenten com a successives, van coexistir sovint en la realitat i que, a més a mess, Nell feia abstracció en el fet que els homes sovint ocupen més d'una posició en l'estructura social: els mercaders podien invertir en terres o manufactures i els nobles podien avençar capital per al comerç. En historia, els casos particulars ofercixen i imposen els límits concrets que assenyalen fins on es pot arribar basant-se només en la sintesi o el raonament abstracte, sovint la història fa recapitular la teoria (lidward J. Ni:L., Relaciones económicas, p. $7(0)$ ).

20) Edward J. Nis.l., Relaciones economicas, pp. 42-4.3. 
i es fonamentava en el control que exercien sobre els mitjans de coerció extraeconòmica (que podríem concretar simpliciter en el poder militar) i el seu predomini descansava en les capacitats productives del camp; mentre el camp és autosuficient econòmicament, la ciutat depenia alimentàriament del camp ".

L'estabilitat d'aquesta situació es veu somoguda durant el segle XII per l'acció combinada d'una sèrie de processos que afecten profundament els àmbits rural i urbà. A partir del segle XII, el creixement de la població, el progrés de l'economia agrícola, l'increment del comerç $\mathrm{i}$ la indústria creen les bases del desenvolupament de la ciutat europea i la progressiva divisió del treball entre ciutat i camp. La fase d'expansió (segles XII-XIII) ve marcada per un fort creixement de la població, una roturació agrícola intensa, l'expansió de la superfície conreada i l'augment secular dels preus "2. Creixement de la població i progrés de l'agricultura van històricament vinculats i s'influeixen mútuament: la disponibilitat de més aliments va provocar un major creixement de la població i el creixement de la població fou un estímul per a l'extensió i intensificació de la producció agrària. Els progressos de l'agricultura no solament estan relacionats amb el creixement demogràfic i l'augment dels preus agrícoles, sinó que també i sobretot són deutors -són producte- d'una sèrie de transformacions: de les tècniques agrícoles, l'estructura agrària i les formes d'explotació. Principalment, el progrés agrícola va estretament vinculat a algunes importants innovacions tecnològiques: millora dels estris de treball agrícola (sobretot la introducció de l'arada de ferro, de nous vehicles i estris), la generalització dels molins, la millora dels arnesos per a bous i cavalls que van permetre un conreu més intensiu i la millora dels rendiments agrícoles i la substitució de la rotació biennal per la triennal en els cultius (la seva introducció permet augmentar la proporció del conreu de verdures, fruites, llegums i vinya respecte dels cereals) $i$, en conseqüència, una millora i diversificació de la dieta alimentària ".

La interacció dels progressos demogràfics i agrícoles amb el comerç i la indústria va permetre sorgir i desenvolupar-se amb força la ciutat i també el començament del domini d'una economia monetària basada en l'intercanvi.

"Per una visió general d'aquest període, vid. Georges DuBY, Guerreros y campesinos. Desarrollo inicial de la economia europea (50)-1200), Madrid, 1976, pp. 199-324, especialment pp. 213-223.

22 M. M. Postan, El comercio, pp. 209-218.

"Lynn WHITE, Tecnologia medieval y cambio social, Barcelona, 1990, pp. 55-95; Charles PARAIN, La evolución de la técnica agricola, in J. H. Cl.APHAM et Eileen POWER (eds), Historia económica de Europa. I. La vida agraria en la Edad Media, Madrid, 1948, pp. 143-203, especialment pp. 154-179; Lynn WHITE, La expansión de la tecnología, 500-1500, in Carlo M. CIPOI.l.A (ed), Historia económica de Europa. 1. La Edad Media, Barcelona, 19872, pp. 152-185, especialment pp. 160-166. 
Amb la multiplicació de les ciutats com a centres de producció manufacturera i d'intercanvi de mercaderies, va produir-se una divisió del treball entre ciutat i camp mediatitzada pel mercat, en la qual el camp proporcionava a la població urbana aliments $\mathrm{i}$ obtenia a canvi mercaderies industrials ${ }^{24}$. Les ciutats progressivament es van alliberar de les restriccions feudals i van desenvolupar un sistema de govern propi; el comerç va romandre relativament lliure de restriccions mercantils i l'entrada en els gremis era relativament facil ". El resultat social d'aquest desenvolupament serà l'aparició i el desenvolupament, durant aquest període, de la nova força social dels mercaders, que assenta la seva puixança econòmica en el monopoli de la informació sobre el comerç i l'aprofita per a beneficiar-se de les diferències de preus; la ciutat esdevé bàsicament centre comercial i el camp (feudalitat i pagesia) esdevé dependent de la ciutat per a la consecució de determinats béns, sobretot de luxe al sud europeu i de primera necessitat al nord ${ }^{26}$.

Amb la productivitat agrícola constant, els preus agrícoles i els ingressos senyorials tendeixen a disminuir. La tendència alcista de la demografia es veu truncada a mitjan de segle XIV pels efectes de la Pesta Negra i les guerres". L'expansió de les ciutats accelera la despoblació del camp perquè la indústria urbana atreu i es beneficia del treball procedent del camp; com a conseqüència de la desproporció entre la demanda i l'oferta de treball, els salaris creixen fermament. Preus decreixents i salaris a l'alça pressionen sobre els terratinents que, per tal d'evitar la fugida dels seus serfs, tendeixen a reduir i commutar els serveis en treball per pagaments en diner $i$, per tal de mantenir els seus ingressos, augmenten les exaccions i extorsions sobre el comerç o bé es dediquen cada vegada més a l'extorsió directa $\mathrm{i}$ al bandidatge ${ }^{2 *}$.

24 M. M. POSTAN, El comercio, pp. 218-222.

2 A.B. HibBERT, La política económica de las ciudades, in M. M. POSTAN, E. E. RICH et Edward MiLleer (eds), Historia económica de Europa. III. Organización y política económica en la Edad Media, Madrid, 1972, pp. 195-289, especialment pp. 227-250.

${ }^{26}$ Michacl M. POSTAN, El comercio, pp. 218-222. Robert S. LÓPEZ, El comercio de la Europa medieval: el sur, in M.M. POSTAN et E.E. RICH (eds), Historia económica de Europa. II. El comercio y la industria en la Edad Media, Madrid, 1967, pp. 327-447. Roberto S. L.Opl:7, La revolución comercial en la Europa medieval. Barcelona, 1981, pp. 141-150; Jacques Bernard, Comercio y finanzas en la Edad Media, 9(0)-1500 in Carlo M. Cipol.ta (ed), Historia económica de Europa. 1. La Edad Media, Barcelona, 19872, pp. 295-361, especialment p. 302.

27 Michael M. POSTAN, El comercio, pp. 274-278; Henri PIRENNE, Historia económica $y$ social, pp. 141-142.

2* Maurice DOBB, Estudios sobre el desarrollo, pp. 62-63; Michael M. POSTAN, El siglo $X V$, in Michael M. POSTAN, Ensayos sobre agricultura y problemas generales de la economia medieval, Madrid, 1981, pp. 54-6.3, especialment p. 63. Si bé Dobb proposà que les pressions inicials de la lluita de classes van sorgir dels nobles; en canvi, Nabholz plantejava que va iniciar-se principalment des de baix de l'escala social (Hans NABHOL.\%, La sociedad agraria 
A les ciutats, la contracció general del mercat i el proteccionisme artesanal provoçuen que la posició dels grans comerciants vagi declinant de manera contínua, mentre que la dels artesans millora ${ }^{29}$. L'època d'or dels mercaders es veu enrunada per la pèrdua de la seva posició econòmica privilegiada com a intermediaris econòmics: els comerciants, en adonar-se que la disminució dels preus agrícoles i l'augment dels preus dels productes tendia a disminuir les oporrunitats d'arbitratge amb beneficis, van començar a comprar terres, tant a ciutat com a pagès (aliant-se d'aquesta manera amb la noblesa) i esdevenir rendistes o bé entrar en la producció industrial a través del sistema de treball a domicili (putting-out system) ". Altrament, l'artesania urbana qualificada desplaçava els mercaders al comercialitzar els seus productes directament, sobretot en aquells subsectors el client principal dels quals era la feudalitat. L'enfrontament social intern a la ciutat entre maiores i minores no va trigar a aparèixer de manera intermitent, però no per això no va ésser menys crispat ". La ciutat deixava d'ésser el vehicle d'expansió d'altre temps: el pes de les seves defenses i l'extremada especialització de la seva estructura van alimentar la seva decadència i el mateix èxit dels seus mecanismes defensius i proteccionistes va agreujar les dificultats econòmicjues, amb la qual cosa va guanyar-se enemics, tant dins com fora dels seus murs".

Així, a la fi del segle XV, les posicions econòmiques predominants de les diferents èlits en competència ja no es fonamentaven en el poder militar, sinó que provenien del control d'una o altra forma de producció o del comerç. Dit en altres termes: la capacitat d'obtenir poder militar que altre temps depenia directament del control de la terra, ara es veia o, almenys, podia veure's desplaçada per unes altres formes de possessió del poder econòmic. La noblesa continuava formant part del bloc històric dominant i gaudia de cert alt grau de siznificació com a classe, però ja no aconseguia mantenir la seva hegemonia en exclusiva en ráó de la seva posició militar: s'havia anat transformant en una classe econòmica, basada essencialment en la terra, però sovint es trobava involucrada d'alguna manera en el comers, compartint la dominació social amb comerciants i gremis d'artesans urbans.

medievisl en s" periodo de transición in J. H. CI.APHAM et Eileen POWliR (eds), Historia eionímica de Europa. I. La vida agraria en la Edad Media, Madrid, 1948, pp. 59(6-677, especialment pp. (6)1-6()2, 6(07-6()8, 618-620).

"Carlo M. CIPO)I. A, Ia politica económica de los gobiernos: las Peninsulas ltaliana e Ibérica, in M. M. POSTAN, F. E. Rich et Edward Mil.I.F (eds), Historia económica de Europa. 111. Orpanización y politica econimica en la Edad Media, Madrid, 1972, pp. 507-546, especialment np. 525-529; Michael M. Postan, El comercio, pp. 278-282.

"Michacl M. Postan, El comercio, pp. 278-286.

"Michacl M. Postan, El comercio, pp. 282-285.

A. B. Hibsirkr, La política económica de las ciudades, pp. 261-289, especialment pp. $288-281$ 
En general, doncs, podem dir que, vers el segle XV i sobretot en la seva fi, s'havia concretat la transició entre una societat amb una classe dominant, de caràcter uniforme i basada en la força militar, fins a una societat en què l'èlit governant s'havia convertit en quelcom més complex i dividit, composta d'elements que depenien d'ingressos de diferent caràcter i amb estils de vida diferenciats, però tots fonamentats en el poder econòmic; mentre que, altrament, el poder militar tendia a concentrar-se en mans d'una autoritat central i que, àdhuc forçant els termes de faisó agosarada, ens permetria parlar d'una mena de feudalisme d'Estat".

A partir de considerar com a pauta per a l'anàlisi històrica el model dibuixat per Nell, el nostre objectiu consistirà a ocupar-nos del paper desenvolupat per la ciutat en la primera crisi general del feudalisme i, considerant la ciutat com a resultat de la dinàmica de les forces socials, endinsar-nos en l'anàlisi factual de l'evolució històrica de la distribució i composició de la riquesa social -posant l'accent, evidentment, en el subjecte històric principal com és l'èlit sòcio-econòmica urbana- en una vila catalana de l'interior (Cervera) durant la segona meitat del segle XIV.

\subsection{La font: el «manifest» cerverí "}

Cal assenyalar, des del començament, que ens hem servit d'una font històrica que considerem privilegiada pel joc científic que ens ha permès com és

"François HINCKER, Confribución a la discusion sobre la transicion" del fiududismo al capitalismo: la monarquia absoluta francesa, in Charles PARAIN, Pierre VII.AR el alii, E:l feudalismo, Madrid, 1976', pp. 89-9), especialment p. 9(). Pel debat historiografic sobre la naturalesa social de l'Estat absolut, vid. Roland MotsisII:R, liurores campesinor. Los campesinos en las revineltas del siglo XVII (Iranciad, Rusia, Cbina), Madrid, 19)76; Roland Mo(sivil:R, La monarguia absolula e" Europa del siglo $V$ a nuestros dias, Madrid. 1986; P(ery ANI)IRSoN,

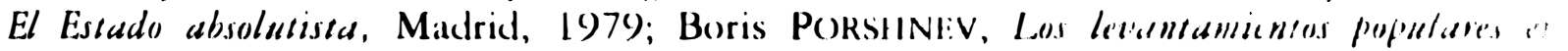

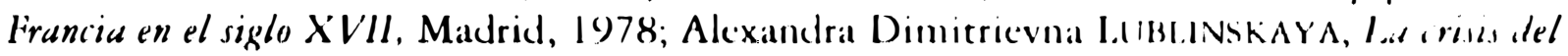
siglo XVII y la sociedad del absolutismo, Barccilonit, 19)79.

"1 La vertebració juridica del Manifest de Cervera l'hem abordat mes a fons i amb

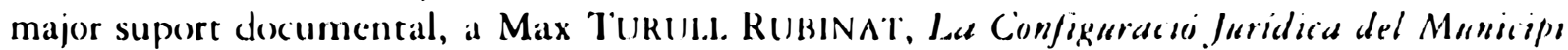
Baix-Medieval. Regim municipal i fiscalitat a Cererera entre 1182 i 14.30, Batrcalona, 19)(1), pp). 493-517. Ara només n'oterim una sintesi esquematica i breu yue permeti al lector de familiaritzar-se amb aquesta font no gaire estudiada a Catalunya. Citcom cls privilegis retals conservats al Fons Municipal de l'Arxiu Historic Comarcal de Cervera $(==A H C C)$ per l'edicu

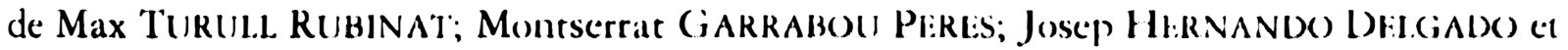
Josep Maria Llobl:T PorTliLl.A, Llibre de Privilegis de Cervera (1/82-1456), Barcelona, 19)1 (en endavant LP i data de concessió del privilegi i numero del privilege con l'esmentada edi(ió). 
el Manifest cerverí. Aquesta és una font estrictament fiscal per la seva naturalesa, ja que el seu objectiu consisteix en confeccionar un cens de la riquesa moble i immoble dels habitants de la vila a fi i efecte de procedir, en el seu moment, al cobrament dels impostos directes l'administració dels quals recau en el municipi. Poc importa ara la destinació de la recaptació que efectua el municipi a partir d'aquesta tributació directa en forma d'impost. El bàsic, en aquest cas, és que el municipi actua com a subjecte actiu d'una relació tributària que té el ciutadà com a subjecte passiu. Un dels elements essencials d'aquesta relació tributària és, precisament, la taxació dels béns dels veïns a partir de la qual es procedirà a la quantificació del deute tributari entre subjecte passiu i municipi. En aquest context, com pot veure's, el Manifest és una font fiscal que, no obstant, informa extensament de la realitat sòcio-econòmica d'una comunitat determinada.

Els orígens del Manifest de Cervera arrenquen del privilegi reial de setembre de 1272, segons el qual Jaume I permet que siguin estimats els béns dels habitants de Cervera amb l'objecte de procedir a recol-lectes, tant les destinades al rei com a la universitat ". Aquesta pràctica de taxar el valor dels béns dels veïns va anar-se perfeccionant al llarg del segle XIV i va constituir allò que anomenem el Manifest. El concepte, documentat a les acaballes del segle XIII ", recull dos significats: d'una part la pràctica de "manifestar" o expressar els béns que cadascú tenia; i d'una altra, la documentació que en resultava, 0 Llibres del Manifest. Sembla que el mètode d'anotar els béns, des del segle XIII, havia d'exigir un document explícit en aquest sentit. No obstant això, els Llibres del Manifest més antics que s'han conservat a Cervera daten del 1340, i no es tracta de sèries completes -quatre volums, corresponents a quatre quarters- sinó de col-leccions incompletes. Fins al 1476 i 1490 no s'ha conservat un Manifest amb totes les estimacions de tots els habitants dels quatre barris de la vila".

19 LP 1272 setembre 3, núm. 14.

"Q "Que los pahers de Cervera puxen tatxar los veyns de la dita vila aprés que ab sagrament hauran manifestat sos bens per mes bens que no hauran manifestats" (I.P 1272 setembre 3, núm. 14).

"El manifest (estima o vàlua segons altres denominacions) com a font fiscal ha estat molt poc estudiat a Catalunya i, en especial, al segle XIV. De moment ens hem de remetre al nostre estudi, Max TURULl. RuBINAT, La hacienda municipal y la tributación directa en Cataluña durante la Edad Media. Planteamiento general, "Revista de Hacienda Autonómica y Local», XXII, 64 (1992), pp. 9-80) (veure també els treballs pertinents en aquest mateix exemplar d' "AEM" $i$ els que es troben en premsa dins del volum miscel-lani dirigit per Manuel SÁNCHEZ. MARTínEZ, Estudios sobre renta y fiscalidad en la Cataluña bajomedieval; títol provisional). Quan corregiem les probes d'impremta del present treball, hem tingut ocasió de conèixer la tesi de llicenciatura de Jordi MORELLÓ I BAGET, Demografia, societat i fiscalitat de Reus al segle XV: el llibre d'estimes de 1445, Departament d'Historia Medieval, 
És clar que el Manifest, ordenat des del mateix Consell municipal, era un cens $i$, per tant, un instrument, una eina $i$ un suport material i no pas cap mena d'impost o taxa. El Manifest contenia l'anotació de la riquesa moble i immoble dels habitants i veïns de Cervera i dels que sense ser-ho hi tenien propietats. Aquestes eren estimades, taxades o avaluades en criteris monetaris, de manera que podia saber-se dels béns immobles o mobles d'un veí en quantes lliures i sous eren taxats.

Sobre aquesta base imponible expressada en diner resultat d'una estimació directa, s'aplicava un gravamen que es determinava cada vegada que calia cobrar un impost directe. De l'aplicació del gravamen en resultava la quota tributària que era la quantitat de diner que el subjecte passiu estava obligat a pagar. La base imponible no variava a cada percepció de l'impost, sinó només quan així ho acordava el Consell. La utilització d'un gravamen que actuava sobre la base imponible podia revestir formes diferents. En el cas del nostre Manifest, aquest gravamen donava peu a un pagament proporcional que rebia

Paleografia i Diplomàtica de la Universitat de Barcelona, Barcelona, 1992; amb abundant bibliografia especialitzada $\mathrm{i}$ amb una anàlisi exhaustiva $\mathrm{i}$ interessant de diferents modalitats de manifests, estimes o vàlues. Les estimes, sobretot amb documentació del segle XV, han estat tractades a fons en cl congrés que tenia per objecte l'estudi de les fonts fiscals a la baixa edat mitjana (Centro) di Studi sulla Civiltà del Tardo Medioevo: 30 Seminario di studi. Fonti per la storia della civiltà tardo medievale: la fonte fiscale. San Miniato (Pisa), 5-12 setembre 1989. A més pot consultar-se, entre d'altra, la següent bibliografia, per bé que serà sempre sobre experiències italianes i franceses: Jean FAVIFR, Finance et fiscalité au Bas Moyen Age, Paris, 1971; tot el conjunt d'articles de les: "Actes du 102 Congrés National des Sociétés Savantes", Études sur la fiscalité au Moyen Age, Limoges, 1977, publicat a Paris, 1979; Enrico FIUMI, L'imposta diretta nei comuni medioevali della Toscana, "Studi in onore di A. Saporim, I, Milano, 1957, pp. 329-353; Charles M. de la RONCIÈRE, Indirect taxes or "gabelles" at Florence in the fourteenth century: the evolution of tariffs and problems of collection, in Florentine Studies. Politics and Society in Renaissance Florence, London, 1968, pp. 140-192; David Herl.IHY, Direct and indirect taxation in Tuscan urban finances (c.a. 1200)-1400), in Finances et comptabilité urbains du XIIle au XVle siècle, Bruxelles, 1964, pp. 385-405; Philipe WOLFF, Les estimes Toulousaines, Toulouse, 1956; William M. BOWSKY, Le finanze del Commune di Siena, 1287-1355, Firenze, esp. pp. 133-152 (=Il Dazio: un'imposta diretta); A. GrohmanN, Il documento Perugino nel panorama degli estimi italiani del sec. XIII, in L'imposizione diretta nei comuni dell'ltalia centrale, Roma, 1986, pp. 1-62. Sobre una presentació com a fonts fiscals pròpies dels commune medievals italians i base d'impostos sobre la riquesa $i$ /o renda dels "estimo, libra $i$ catastro» $i$ una valoració general de les seves virtualitats heurístiques $i$, en especial, la cautela específica amb que han d'ésser emprades, vid. Carlo M. Cipolla, Entre la bistoria y la economia. Introducción a la bistoria económica, Barcelona, 1991, pp. 139-144, especialment p. 144. Per a un model ja clàssic per la seva qualitat en el gènere, vid. David HERLIHY et Christiane KLAPISCH-ZUBER, I toscani e le loro famiglie. Uno studio sul catasto fiorentino del 14, Bologna, 1988, sobre la font, vid. pp. 19149. 
el nom de "per sou i per lliura" ". El sistema, basat en una distribució alíquota proporcional, consistia, un cop coneguda la quantitat total del tribut a recollir, que aquesta repartició s'havia de dividir proporcionalment entre les quantitats estimades dels béns mobles i dels immobles.

El Manifest, com a document físic, que recollia la base imponible dels habitants i veïns, no s'elaborava cada any ni tampoc en funció de cada tribut. La seva confecció, òbviament costosa ", era irregular. Un mateix Manifest degudament esmenat servia per a uns quants anys quan s'introduien les esmenes oportunes en la base imponible estimada dels subjectes passius. Aquest reaprofitament dels documents explica que alguns siguin fins i tot difícils de llegir per l'abundàcia d'esmenes, interlineats i esborrats que presenten ".

is L'any 1332, per exemple, es va regular que el gravamen en una talla determinada consistía que cada lliura de béns mobles pagués 4 diners, mentre que per cada lliura de béns immobles (o siti) estimats es pagarien 2 diners (AHCC, Consells 1332-1333, 27 r.); cll1378 es pagaval 6 sous i 2 diners per lliura de moble i la meitat justa per lliura d'immoble. (AHCC, Manifest M 1378, 1 r) i cls anys 1.384 i 1393 cl tipus cra de 3 dincers per lliura de moble i la meitat per immoble (AHCC, Claveria 1984, 4 v; Consclls 139)3, 22 v).

") La noticia que tenim de l'agost de 1395 es ben significativa dels problemes que devial engendrar constantment qualsevol Manifest. Sembla que alguns veïns es queixaven que el Manifest vigent cra mal feet i mal repartit, de manera que uns pagaven més que altres. Aquests veïns exhortaven els pacers "que guarden que negú no port lo fex de l'altre, ans cascú port son feix". Lil cas és que el Consell decidia de fer manifests nous on tothom pagués pel yue tingués, per sou i per lliura (AHCC, Claveria 1383, 53 r; Consells 1388, 18 v; 1395, 2 r).

"A I'AHCC es conserven volums dels manifestos dels anys 1340, 1.352, 1355, 1366 , 1369, 1371, 1375, 1377, 1378, 1382, 1397, ctc... (AHCC, Fons Municipal, sèric Manifest). Aixio no obstant, tenim noticies de la intencio d'elaborar-ne d'altres que no consten en acyucstat relacio de dates. Al final de juliol de 1372 uns quants assistents al Consell expressaven la necessitat de procedir a fer un Manifest nou, aprofitant que calia tallar la questics i yue el Mannifest vigent oferia deficiencies (AHCC. Consells 1372, 3.3 v). Lils paers i consellers del 1377 ja van manar fer el Manifest de cadla quarter a la primera sessió de la seva kegislatura, 1 anunciaven als veïns que durant rot el mes de gener podrien -haurien1'anunciar els béns mobles, censals i violares que renien, la cqual cosa, d'altra banda, sembla yue estableix ja ma distincio entre el yue és moble i immoble (AHCC, Consells 1 377, 2 r). L'any sobre sembla que es tornava a fer un alere manifest: "Item com per pagar los carrechse les necesitats de la universitat lo Conseyll agues acordat que manifests fosen feits e que fos feiral I" raylla (...)" (AHCC, Claveria 1.378, 76 v). Eil motiu que va empinyer a fer un nou Manitest l'any 1381 resta palès en apuest fragment d'un llibre de Clavaria: “(..) moles singulars de la dita vila havien guanyat e altres perdut e altres comprat e altres venuts, fo acordar yue fossen fers manifests per rots los singulars de la dita vila (...) (AHC. (., Clat veria

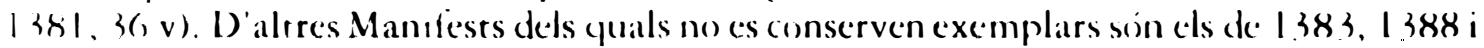
1305 lin el segon seepee ificava que es faria un Manifest per a la talla i que tothom hauria de manifistar "per mercaderna o per mercaldejarm. En alquest Manifest s'hi haurien d'incloure cavalls, muls a mules dets guals hom pongucis treure bencficis. 
Per tant, és evident que la confecció d'un Manifest era quelcom important i transcendent per als veïns. De la taxació o valoració dels seus béns que es fixava en la base imponible en depenia la quota que haurien de pagar una vegada aplicat el gravamen concret per a cadascuna de les talles (amb diversos destinataris) que es "plagarien» no tan sols aquell any, sinó probablement durant més temps. Cal comptar, doncs, que devia existir un nivell de frau clue no hem quantificat. Per aquest motiu s'havia regulat que els paers poguessin rectificar la base imponible dels veïns, tant en la quantitat de béns manifestats com en llur estimació quan el manifestant els conferia un valor inferior al real. Tot i que la garantia que el pagament es basava en un gravamen a parts aliquotes proporcionals havia de tranquil-litzar els més desfavorits, en canvi ens consta que l'status social afavoria una interpretació diferent de la normativa existent referent al pagament proporcional ".

La comprensió exacta del funcionament i de l'estructura del Manifest requereix resoldre, en aquesta ocasió i per als nostres propòsits immediats, com a mínim dues qüestions clau: què s'havia de manifestar? qui estava obligat a fer-ho? El fet imponible radicava en el fet de gaudir d'uns determinats paràmetres de riquesa que plegats configuraven l'objecte del tribut. Acyucst objecte del tribut es classificava en béns mobles i immobles (moble i siti) ", de

$"$ El cas relatat a la sessici del 26 de setembre de 13.32 es forga interessant. Fenat referència al privilegi recentment atorgat pel rei (cal entende el de $1.331=1 . P 1331$, setembre 10, núm. 38), i més concretament a allo que havien de patgar per contribuir a taxe's veïnals aquells que «ayen iurat si no aver neguns bens siens ni movents». Que algun sector social manifestés sota jurament ser insolvent $i$ no poder contribuir al fisc municipal engendrava dubtes d'interpretació del document en una part del Consell, motiu pel qual proposaven de trametre una comissici al rei per a dilucidar qui havien de fer. Perie un altre sector del Consell no estal va d'acord a enviar cap comissió con la propossada. Per a cells erat molt clar el sentit del Privilegi, i exigien que "segons sa tenor fos observat". Aixio és: "yue molt ha, que pach molt; qui poch ha, poch pach; e qui res no ha, que no pach res" (AHCC, Consells 1332-133.3, 28 v). Lil problema de la contribució dels més pobres es repeciria mes endavant. El 1,377 el Conscll decidia que aquells cue no pagaven segons el Manitest perquie no tenien ni rendes (censals o violaris) ni tampoc bens mobles, tambe haviende col laborar

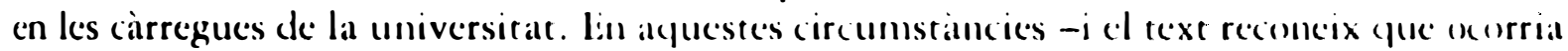
en molts casos-, cren els matcixos "talladors" cls qui a ull havien de "tallat" la massat

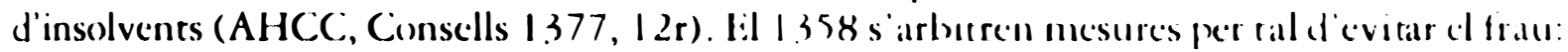
pèrdua dels béns ocultats (AHCC. Consclls 1358, 28 r); i el 1378 , “molts de la dita vila en gran dampnatge dels afers de la universitat recusen de fer lur manitest ( $A H C$ C. Manifest $M$ $1378,1 \mathrm{r})$.

". Luis G. de Valdeavellanos' ha precocupat d'estudiar el concepte be moble i immoble.

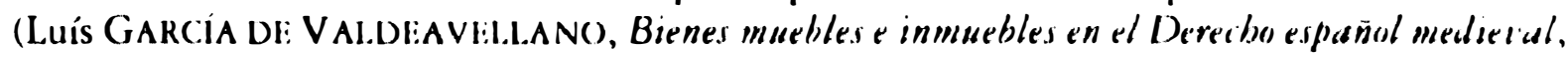
"Cuadernos de Historia de España", XI (1949), pp. 105-12.3). Segons l'autor, la distincio era poc significativa en el dret roma, i considerable a l'altat edat mitjanal en virtut de lat influència germànica. La "Recepcio»-scgons Valdeavellano-tan sols va modificar el critcr 
manera que es valoraven els béns materials més menuts (plats, coberts, cadires,...); qualsevol tipus de renda provinent de capital invertit (censals $\mathrm{i}$ violaris); préstecs que ha deixat i encara li són deguts; albergs; obradors; qualsevol tipus de terra (alous, vinyes,...); serveis cedits que li remeten algun tipus de guany econòmic (escrivanies, arrendaments,...); quantitats de gra $\mathrm{i}$ safrà; herències; i en general qualsevol mena d'ingrés per qualsevol concepte possible ".

Respecte dels subjectes passius que estaven sotmesos a l'obligació tributària, cap privilegi no explicita de qui es tracta exactament, per la qual cosa hem de constatar allò que es dedueix de la pràctica documentada. En primer lloc ens adonem que no coincideix la finalitat per a la qual es confecciona el Manifest i el mitjà que s'utilitza en el procés. Mentre que la finalitat és exclusivament fiscal $\mathrm{i}$ implica un recompte $\mathrm{i}$ una recollida dels tributs a partir de la riquesa concentrada en cada foc, la propietat d'aquesta riquesa no és unitària a cada foc. I això en el sentit que, mentre que el Manifest pretenia recollir les propietats que convergien en un foc i que s'adscrivien a nom del cap de família a efectes fiscals, la realitat de la propietat no era tan monolítica. El règim dotal de separació de béns entre els cònjuges permetia que la dona mantingués una porció de béns, a més a més de la possibilitat que, a la mort del marit, es convertís en tutora preferent dels béns dels fills. Tota aquesta situació no era reconeguda en el Manifest, ja que la seva finalitat sembla que no era saber a qui pertanyia la riquesa en el si d'una família, sinó comptabilitzar el total de la riquesa d'aquella família, que era, en definitiva, la unitat fiscal sobre què s'aplicaven els tributs del municipi. A part d'aquesta primera apreciació, cal indicar que un individu pagava tributs a la universitat a partir d'una obligació real i una altra de personal. El subjecte passiu havia de contribuir no tan sols a

de classificar els béns. A "Las Siete Partidas» (11, 17, 1; II, 18, 1; III, 29, 4) el criteri de classificació era la característica de mobilitat $\mathrm{i}$ immobilitat dels béns. "Però Las Partidas, inspiradas en el derecho romano, no recogen en su definición el verdadero concepto que de los bienes muebles e inmuebles tuvo el Derecho español medieval». Aixi els immobles devien estar vinculats a la propietat del grup familiar, i els mobles a la propietat individual. La classificació de béns mobles i immobles no és gaire clara, i així ho manifestava Iglesia a partir de la documentació de Sant Cugat (Aquilino Iglesia Ferreiros, El Cartulario de Sant Cugat del Vallés: del "Liber ludiciorum" al "Corpus luris Civilis", in I Seminario de Historia del Derecho y Derecho Privado. Nuevas Técnicas de investigación. Bellaterra, 1985, pp. 93176).

"Un exemple de l'abast dels béns taxats ens l'ofereix qualsevol manifest d'algun personatge important: Berenguer de Cardona (AHCC Manifest M 1366, 40)bis, 1 i 2). I també Antoni Toldrà, el manifest del qual ja vam publicar a Max Turull RuBinat, Antoni Toldrà (notari del segle XIV) i la Summa Rolandina, "Miscel lània Cerverina", 6 (Cervera, 1988), pp. 27-51. 
causa de la seva domiciliació, sinó també perquè tenia propietats dins els límits de la vila. Podem dir que els habitants i els veïns o ciutadans estaven obligats, en virtut del pacte que regulava la seva situació, a contribuir a les despeses comunes de la vila $i$ en aquelles a què la comunitat estava obligada com a col-lectiu. Però també tenien l'obligació de pagar aquells individus que, sense ser veïns de la vila, hi tenien propietats. Així, un ciutadà de Lleida que tingués una vinya al terme de Cervera estava obligat a contribuir pel valor de la vinya a la universitat de Cervera, i no a la de Lleida d'on era veí ${ }^{44}$.

Comptava, doncs, també la ubicació de la riquesa, i no únicament la propietat d'aquesta riquesa. D'altra banda, recordem l'existència d'aquell privilegi del 1.373 segons el qual abandonar el veïnatge no alliberava automàticament de contribuir. En aquests casos calia col-laborar, proporcionalment als béns que hom tenia, amb els deutes que la universitat tenia pendents ". La introducció al volum del Manifest de Montserè de 1378 documenta alguns d'aquells aspectes que podien ocasionar dubtes $\mathrm{i}$ afavorir el frau entre els veïns *'.

El Manifest de cada foc recollia, encara que no sempre, la següent informació: nom del cap de família, a qui s'adscrivia la relació de béns; professió de l'individu; nom del declarant i tipus de relació amb el titular en els casos que no declarava el cap de família sinó una altra persona en nom seu; relació minuciosa dels béns mobles i immobles amb l'estimació de cadascun d'aquests expressada en lliures, sous i diners; i adscripció administrativa per quarters i carrers. Al final de cada Manifest es resumia el total taxat de béns mobles i el total de béns immobles. De manera que, en definitiva, es valorava, en xifres absolutes expressades en moneda i segons criteris de mercat, tota la riquesa d'un individu, tret dels casos particulars en què alguns béns gaudissin de franqueses ${ }^{4}$.

14 El mateix cas però a la inversa ens el torna a oferir el notari Antoni Toldrà. La seva esposa Margarida tenia una casa amb alguns estris a Lleida, per les quals propietats sol- licitaven de no ser taxats ja que ells contribuïen per la casa i estris amb la questia recaptada per la Paeria de Lleida: «(...) Margarida muyler sua, manifeste e diu cue la dita dona ha en la ciutat de Leyda un alberch lo cual ja questicye en la dita ciutat, c axi requer que no sie tayllat ne per aquell contribuesque, lo yual emperio presc...) (AHCC, Manifest M-1366, 43 i ss, 1 a 7; publicat a TuRULL., Antoni 'Toldria).

1) LP 1373 maig 20, núm. 102.

40 A propòsit del canvi de domicili i ampliant les resolucions, els paers i prohoms acordaren el següent: "(...) que la dita forma e manera sie tenguda e servada en tots aquells qui lurs animes faran o transportaran lurs bens en persones que no contribuesquen ab la universitat, axí que los bens lurs, axí moble com sients, sien estimats e de la quantitat a que muntaran paguen a traure e rehebre los deutes de la dita universitat per moble e per siti per sou e per lliura, segons que faran aquells qui lur domicili transportaran». (AHCC, Manifest M 1378, 1 r).

4) És facil de trobar exemples on el Consell, necessitat de diners amb urgència, venia 
Però a l'hora de valorar la font que utilitzem s'han de tenir en compte no sols els subjectes i els béns que estaven obligats a ser declarats, sinó també el procés que això comportava. En el Manifest de Cervera dels segles XIV i XV, els mateixos veïns declaraven sota jurament els béns i el seu valor. Els càrrecs nomenats pel Consell controlaven aquestes declaracions i les esmenaven quan les consideraven efectuades amb una estimació inferior a la real. Els béns dels ciutadans absents eren declarats i estimats pels seus veïns, cosa que també es feia sota control de càrrecs municipals. Per tant, en el Manifest de Cervera d'aquesta època no existia un peritatge ni una valoració tècnica de la riquesa, sinó una declaració dels propietaris. Només a partir d'un moment que no podem determinar, van participar experts en la valoració dels béns dets veïns ". D'altra banda, aquest procés de confecció del Manifest, coordinat i dirigit des del Consell, havia de permetre un grau no determinat de frau fiscal «comú» $\mathrm{i}$ també una certa dosi de frau fiscal "polític» en el marc d'un govern local considerablement oligàrquic els segles XIV $\mathrm{i} X \mathrm{XV}^{\prime \prime}$.

\section{I.3. La metodologia: estadística històrica}

La pertinença de la nostra font quedava prou palesa en el subapartat

censals o violaris francs de questia. Fn aquests cassos el capital invertit d'aquell veí no estaria exposat a contribuir en aquell tribut pel qual havia estat enfrancyuit. El cas del notari Antoni Toldrà n'és un clar exemple. Els seus béns "siti» (immobles) eren inicialment valorats en 2.117 lliures, 5 sous i 4 diners, però «abatuda la franquesa del sensal e del violari», passaven a valorar-se en 1.238 lliures i 3 sous. Per tant, els capitals del censal i del violari cuuedaven excompts de qualscevol calcul amb finalitats fiscals (AHCC, Manifest M-1366, 43 i ss. (1-7); publicat per 'TURULL, Antoni 'Toldrà, 51). Lin d'altres ocasions la franquesa podial affectar l'acte de manifestar els bens. Aixi) succeïa sobretot en els contractes de veïnatge i en els capitols que establia el Consell amb un metge o un mestre perquie s'establissin a la vila. 'Tret d'aquells casos privilegiats, el Consell s'afanyà a indicar que res no desgravava, cosa que pretenien alguns prohoms que tenien censals $\mathrm{i}$ draps i mercaderies provinents de penyores (AHCC, Consells 1377, 13 v.).

in Un document del 1745 exposava els orígens (no gaire remots, però) de la "quístia arbitrària»: "Per la intelligència de la nova formació del llibre del Manifest, per lo qual se regule lo producte de la Quístia, per estar en el lo valor de totes les terres i cases de la ciutat y son terme (..) També se a de suposar que en los temps antecedents per la formació del llibre del Manifest nomenave la ciutat pagesos, fusters i mestres de cases experts, que judicaven les cases i medien les terres, y segons sa relació se continuave en die llibre la estimació que se donave a cada propietat (...)". (AHCC, Fons Municipal, Llibre original de la Quístia de $1745,1 \mathrm{r}$ ).

"Sobre la regulació jurídica i en general tot el procés de confecció del Manifest i les característicues sicio-políticues del Consell de la Pacria, vegeu T'Turul.t., La Configuració 
anterior; mentre que la reorganització de les dades, en el nostre cas, es reducix a la classificació de les diferents ocupacions/oficis dins categories sócioprofessionals més àmplies i significatives ". Hem decidit optar per una classificació centrada en l'esquema dels sectors econòmics, seguint Colin Clark "; però modificant-la en el seu interior a partir dels criteris de recerca pràctica de Maria Luiza Marcilio" per a societats pre-industrials.

Juridica del Municipi, pp. 493-517 i 587-619) i La Hacienda municipal y la tributación directa en Cataluña. pp. 32-75; vid. nota 30.

"Si be la bondat, en alguns menesters d'historia scicio-comomica, de l'estaldésticat historica és fora de dubece, cal anar en compece en un procés delicat i alhora dificultós de la tasca com és la codificació de la informació disponible: des de la font al la interpretació, cal travessar el riu de la lectura i crítica textuals (Jacques DUPAQUIIR, Problèmes de la codification socio-professionale, "L'histoire socialc. Sources et mithodes", (Paris, 1967), Pp. 157167). En el nostre cas, la fiabilitat i l'interès de la font jat han estat posats de manifest en el subapartat anterior, però ens yueden per fer dos detalls metodolongics: la codificacio de les diferents categories socio-professionals cuc aniran desfilant pel nostre estudi i la justificació de les diferents tècniques estadísticjues que emprarem. Fa ja cert temps, Furet va establir alguns criteris metodologics per a la practica de la historia quantitativa (François Furl:T, Libistoire quantitative et la construction d" fait historique, "Annales. Bconomies. Socictés. Civilisations» num. I (janvier-févricr, 1971), pl). 63-75); contre acpuedls, con destacaval l'ús de les fonts estructuralment numèriques, pero cue l'historiador utilit zal de mancrat șubstitutival per tal de trobar resposta a yüestions completament alicines al seu camporiginal de recercat. I Furet aportavat com a excmpless d'acpuest ús cels següconts calsos: l'analisi de comportaments sexuals a partir de registres parroguials, l'estudi del creixement economic a partir de sirries de preus i -aixi) és cl cue acyui ens interessa- l'évolution socioprofessionnelle d'une population is partird'una série fiscale (FURE'T, L'histoire quantitatio'e, PP. 7()). Puret cons advertial, peró), que la tasca de l'historiador esdevenia difícil per duess ratons: d'una banda, la cüuestio de la pertinença -la font no ha estat confeccionada pas en funció de l'us que se li dona $i$, per tant, cal establir meticulosament el lligam- i, d'unal altrat, la yüestici de la presentacio del material -cal reorganiezar completament les dades de la font per a fer-les utilitzables, la yual cosa peca

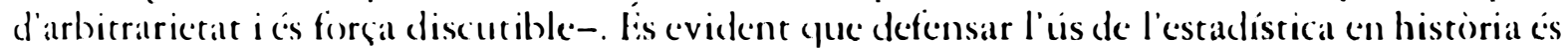
avui en dia impossible si no es compta amb el suport d'estris informatics (bases de dades i fulls de (älcul) i si be entre els nostres historiadors d'epocpues més recents atixo seria superflu de dir-ho pels abundosos exemples, en historia medieval la nostra situacio cont rasta ambel

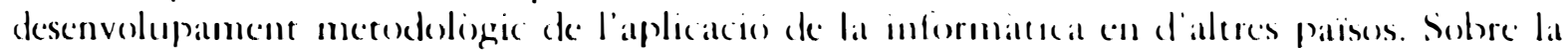

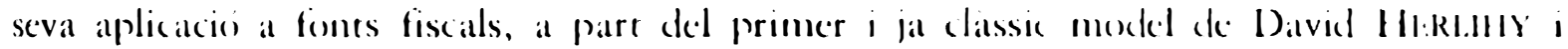

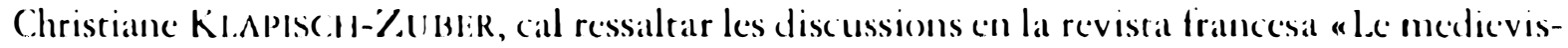
te ce l'ordinatcurs III (I9)8()), PP. 5-9); VIII (1982), PP. I-4, 8-13; IX (1983), Pp. IG2().

"Colin (i.Ark, Lass condiciones del progereso ecomoimico, Madrid, 1971, 2 vols.

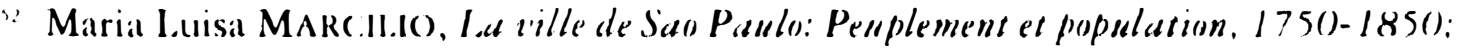
Universite de Rouen, Rouen, tesi doctoral inedita, pp. 152-154. Citat a: Ciro Flamarion SANTANA (ARIX)SO/Héctor PI:RI:Z. BRIGiN()I.I, Loss métodos de la historia. Introdución a los problemas, métodos y teinnicas de la historia demografica, econoimica y social. Barcelona, 19)79) (1976), Pp. 3(1)7-3()). 
Bàsicament, Colin Clark distingia tres sectors d'activitat: el primari o d'extracció de productes de la natura, el secundari o de transformació dels productes i el terciari o d'assegurança de l'existència dels dos sectors anteriorsproductius. Les modificacions de Maria Luiza Marcilio no eren de substància, ja que mantenia l'esquema essencial de Clark; però incloïa, dins el secundari, totes les manufactures i formes d'artesanat i distingia, dins el terciari, entre professions liberals, església, administració civil, comerç, transport i algunes altres".

Queda, però, pendent la posició de la gran massa d' «indeterminats» que, en principi, incloem com a "sense professió»; és ben natural pensar que, en una societat pre-industrial i predominantment agrícola com la feudal, la-majoria d'habitants signin, de professió, pagesos: la normalitat, representada per la pagesia, no cal diferenciar-la en un llistat fiscal com el «Manifest» i, en canvi, és força més corrent identificar seriosament aquelles que són diferents del normal. A més, segons les consideracions fetes per Hilton sobre la pagesia com a classe, aquesta darrera en època feudal pot desenvolupar indiferenciadament diferents posicions de funció econòmica concreta depenent de l'època concreta del cicle econòmic anual; però la professió fonamental, i condicionant de la seva condició social, és el conreu del camp ".

Una altra qüestió de codificació de dades, que es presenta com a força important en el nostre cas, és la distinció entre béns inmobles i béns mobles: si bé, des d'un punt de vista teòric i general -el del dret-, ja n'hem fet la diferenciació en el subapartat anterior, ens queda recolzar-lo en l'evidència empírica representada per l'anàlisi d'un cas concret d'extracte de "Manifest" individual. A partir de les dades empíriques concretes de la manifestació del notari Antoni Toldrà ", podem perfectament delimitar-ne la diferència -a grans trets- com segueix: són considerats com a béns immobles o «siti» la terra, les cases, els arrendaments, els censals i els violaris; en canvi, són béns mobles els productes agrícoles, els animals de càrrega i agrícoles, els estris de tota mena $i$ el diner en efectiu.

Per a l'estudi de la distribució de la riquesa social hem emprat la corba de Lorenz, l'índex de Gini “, i la corba de Pareto, i els pendents de la regressió ".

"Per veure la nostre opció concreta, dirigiu-vos a la ligura 1.

". Rodney H. Hilton, El campesinado como clase, "Lstudis d'Historia Agrària», I (1978), pp. 27-37, (sp. p. 34).

"Vid. nota 39 .

"Per la corba de Lorenz i l'índex de Gini, vid. Alfonso Garcia Barbancho, Estadistica elemental moderna, Barcelona, 1987 (1973), pp. 91-97. Per les seves característiques, confecció i interpretació, vid. nota 79.

"Pel que fa referencia a la corba de Pareto i els seus pendents, cal aclarir que es tracta d'un model econometric, ideat per Pareto (Vilfredo PARETO, Cours d'économie politique, 
Tots quatre tenen objectius semblants, però podem fer-hi una doble distinció: mentre que les dues corbes són representacions gràfiques del fenomen $i$, per tant, qualitatives, l'índex i el pendent són valors numèrics que resumeixen les representacions gràfiques $i$, per tant, són quantitatius,; d'altra banda, mentre que la corba de Lorenz i l'índex de Gini s'interessen pel grau de concentració de la distribució, la corba de Pareto i els seus pendents mesuren el grau de desigualtat en el repartiment de la riquesa a mesura que ascendim en l'escala social, és a dir, mesuren el "tamisat» de la distribució ". En el capítol, dedicat a l'aspecte polític, on intentem posar en relació els diferents càrrecs polítics municipals amb els seus status econòmic i professional s'ha emprat-com a assaig metodològic a causa de les limitacions de les fonts- l'estri estadístic anomenat tipificació ".

Lausanne, 1897, vol. II, part. 1, cap. I) i fonamentat en la tècnica estadística de la regressió entre dues variables (José M. RASO/Javier MARTín VidF/Pedro Cl.Avero PARICIO, Estadística básica para ciencias sociales, Barcelona, 1987, pP. 203-224. Robert S. PINDYCK/Daniel L. RuBinfel, Modelos econométricos, Barcelona, 1980, pp. 25-3()7). Per conèixer la natura i la confecció d'aquesta cina estadística, podeu consultar l'exposició de Oskar Lange (Oskar LANGE, Introducioín a la econometria, México, 1974 (1964), pp. 147-16.3). Com a excmple pràctic d'aplicació, vid. Enric Tililo Araciay, Propietat agrieria i percepió de rendes. El paper de l'endeutament en la distribució social de les terres (Cervera, 1744-45), "Estudis d'Historia Agrària", 6 (198.3), pp. 57-99). Igual que les corbes de Lorenz, la corba de Parcto es fa servir generalment per a estudiar la distribució d'ingressos més que no pas dels patrimonis (en el cas paretià, es centra particularment en el segment poblacional d'ingressos més alts), encara que el mateix Lange suggeria que, fins i tot, seria més adient fer-les servir per a estudiar el repartiment de la propietat de la terra i d'altres béns de producció, és a dir, els patrimonis (LANGE, Introducioón, pp. 158). En qualsevol cas, l'ús de la corba de Pareto, com a mesura estadística, és perfectament aillable del context teòric i històric ultraconservador en què fou ideada pel seu autor.

is Per tal d'entendre correctament els resultats derivats de l'ús d'aquest model economètric, cal fer les següents indicacions: el decreixement relatiu (el tamisat) del nombre de persones a mesura que l'ingrés augmenta és menor cadla vegada i disminueix en proporció a l'ingrés, és a dir, l'expectativa matemàtica del tamisat relatiu decreix en proporció a l'ingrés (LANGE, Introducción, pp. 152-15.3); tot això significa, en la pràctica, que els pendents de les distribucions augmentaran a mesura que ens desplacem cap al sector més ric i la recta adopta la curvatura característica (TLLL..O, Propietat agrieria, p. 95). Lins queden pendents, en la presentació dels estris estadístics, les regressions simples yue hem usat per a estudiar la composició tècnica de la riquesa en dependència del nombre dels manifestants. Fexplicant-nos cal dir que, en resum, es tracta de simples regressions unicyuacionals de dues variables que hem ajustat utilitzant equacions simples (PINI)YCK/RUIBINFEI.D, Modelos, pp. 27-81). Evidentment hem hagut de despreciar els valors nuls dels indigents perqué, si els haguéssim considerats, això hauria significat oblidar-nos de la fiabilitat del métode estadístic per simples raons matemàtiques.

s" L'estudi de la relació entre la detentacioi de determ inades responsabilitats polítiques 
Com el nostre objectiu consistirà bàsicament en presentar les característiques essencials de la riquesa social de la vila de Cervera a mitjan de segle XIV; com treballem bàsicament amb patrimonis, cal que fem, abans d'iniciar la nostra exposició, un seriós advertiment sobre les condicions que ens imposa la documentació en el nostre estudi: el fet de treballar amb una font centrada en patrimonis ens permet sobretot presentar una visió estructural-estàtica de certes garanties, mentre cue qualsevol intent de realitzar una visió genètico-dinàmica haurà de limitar-se i només haurà d'ésser entesa com una indicació de tendències; la nostra estratègia d'exposició científica consistirà bàsicament a fer una sèric continuada de fotografies estructurals d'uns mateixos objectes, amb la qual cosa esperem obtenir una mena de simulació de cinema genètic.

La síntesi de la genètica ens presentarà la diferenciació social i l'especialització espacial resultants i producte d'una llarga evolució històrica, de la qual entenem que el període corresponent a la segona meitat del segle XIV és crucial per a determinar-ne la direcció de l'evolució.

\section{ELS CONDICIONANTS HISTÒRICS: POBI.ACIÓ I DIVISIÓ DI: L.'ESPAI A CliRVIERA Al. SLICILI: XIV}

Considerar teòricament la ciutat medieval com un corpus aillat del seu

en el Consell cerveri (paers, consellers i prohoms electors) i cls diferents nivells cconomics i ocupacions professionals de les persones que cls ocuparen presenta, a nivell metodoliogic, certes i cvidents dificultats: com posar en relació i mitjançant quins paràmetres vàlids uns cärrecs cue apareixen vinculats amb nivells economics cjue, en principi, venen expressats de forma absoluta?. Incarar-se a les xifres absolutes és no sols insuficient, sinó i sobretot enganyador: acpuestes xifres expressen uns patrimonis que necessariament ofereixen unes imatges eshiaixades de lat realitat social ja cue és indefensable i rebutjable, adhuc a priori, per un historiador el manteninent constant de les variables economiques ja que, evidenement i primer que res, els patrimon is dels individus depenen directament de la conjuntura economical existent. lil salt metedolingic necessari per atansar-nos al l'estudi comparatiu de comportaments politico-economics ha estat possible, salvant les dificultats -per primera i cinica vegada favorables al reduir l'univers poblacional-inherents a la font, gracies a tipificar lat variable ricguesa total de cadascun dels individus identific ats com a detentadors de carrecs en el gevern municipal. Tipificar una sèric estadestica determinada significa aconseguir matematricament que, per estandaritzar els seus valors i fer-los comparables, cl valor de la sevat mitjana aritmetica sigui zero i la seval desviacio típica sigui u. Per les característicjues, confeccioi i interpretació d'una variable tipificadia, vid. Alfonso (iARcia Barbancho,

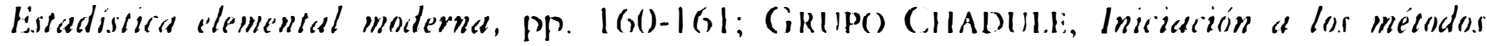
estedisticos en (ieogrefiad, Barcclona, 1980, p. 9); amb scmblants virtualitats cxplicatrives -encara eque centrades sobre el seu ús en la corba normal-i aplicada a dackes historriques, vid.

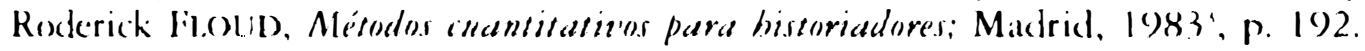


context feudal agrari és un abús; però, potser i comptant amb serioses raons analítiques i documentals, hi ha poques solucions de continuitat en la recerca: els únics òrgans productius de documentació en l'època medieval són, o bé els senyors feudals i assimilats (convents, esglésies, etc), o bé la universitas; tanmateix la ciutat, físicament separada del camp per la muralla $i$, sòcioeconòmicament, per les activitats productives de certs oficis, és un àmbit diferenciat, no pas isolat, de la història.

En aquest sentit, a la Baixa Edat Mitjana, la regió de Cervera era una zona altament poblada amb un clar predomini dels nuclis de jurisdicció senyorial, on el $48 \%$ de la població de la vegueria pertanyia a senyories laiques i el $18 \%$ a eclesiàstics, segons el fogatge de 1365-1.370. També en el context de la vegueria, la distribució geogràfica dels nuclis de poblament ens assenyala una xarxa amb un sol centre demogràfic principal. Cervera era, i amb diferència, l'assentament més important en un ampli radi d'acció. Envoltaven la vila centres de menor pes demogràfic, el més important dels quals tenia uns dos-cents focs quan a Cervera se'n comptabilitzaven més de mil. Això no obstant, es tractava de petites poblacions sotmeses a jurisdiccions feudals que formaven agrupaments humans concentrats. Pel 1.378 una quarta part de la població de la comarca més pròxima a Cervera es concentrava en aquest centre principal.

En el context del Principat, Cervera se situava al segle XIV entre una de les viles i ciutats més importants pel que fa al pes demogràfic, després de Barcelona, Perpinyà, Lleida, Tortosa, Girona, Tarragona i Puigcerdà.

Pel que fa a la població de Cervera, i havent renunciat a creure en la continuïtat del poblament antic, el caràcter de les fonts no permet de fixar amb prou claredat l'evolució cronològica de la població absoluta de la vila.

Amb la documentació a l'abast, considerem que les xifres del fogatge de les Corts de Cervera i Tortosa probablement no eren tan exagerades com ho aparentaven, almenys pel cue fa a la població de Cervera. El 1331 es parlava de $1233 \mathrm{focs}$, i el 1360) un volum de Clavaria xifra la població en 1212 focs. Si bé és difícil arribar a conclusions clares respecte a les xifres de població alosoluta (els 1044 focs de 1.379 enterboleixen la panoràmica), sí que pot observar-se amb certa claredat una tendencia general classificable en tres períodes: abans de 1348; entre 1348 i el recompte de les Corts de 1.365-1.370); i el període que va del final dels anys setanta endavant. També les xifres de les estimes dels volums del Manifest demostren una davallada general de la població al llarg del segle XIV. Així s'observa inequívocament als quarters de Cap Corral entre 1340)1369, a la Plaça entre 1.352-1.366-1.382 i a Montserè entre 1.374-1375.

Pel que fa al medi construït, Cervera al segle XIV era una vila emmurallada que havia crescut a partir del castell. Aquella primera edificació militar del començament del segle XI va propiciar un creixement al seu redòs, a la vora del turó de Montserè, que amb el temps s'estendria pel Coll de les Savines, i seguint 
el camí que pujava des de la vall, travessava el desnivell que uneix Montserè i Coll de les Savines i retornava de nou a la vall per on transcorria el camí «Real». Per tant, la forma que anava prenent la vila responia a dos factors: la topografia del terreny i les necessitats econòmiques d'abastar el Castell i els voltants de productes i mercaderies. Al voltant dels terrenys més accessibles i seguint les vies de comunicació, hi aniria creixent una vila que als segles XII i XIII tenia aspecte de vila closa $i$ que al segle XIV va ser amplament emmurallada. El barri de Cap Corral, que creixia fora muralles, va tenir el seu mur defensiu en una data més tardana.

Les muralles fixaven els límits de la vila, però la jurisdicció d'aquesta darrera s'estenia pels seus termes. A partir del 1331, el municipi apareixeria idealment dividit amb finalitats administratives en quatre barris, circumscripcions o quarters (Cap Corral, Plaça, Montserè i Framenors). Aquesta partició tindrà una transcendència essencial no tan sols a efectes polítics sinó que hi involucrarà tota l'administració municipal $i$, per aquesta raó, és la matriu generadora del Manifest que, en definitiva, és la font que ens interessa "

La partició de la vila en districtes o quarters és un fet que trobem documentat en les teories urbanístiques del segle XIV. Francesc Eiximenis, que va viure entre 1330 i 1409, va teoritzar $\mathrm{i}$ justificar la partició dels centres urbans en quatre parts. La partició responia a criteris administratius, tal com ho veiem a l'explicació que en fa en el Dotzè del Crestià quan indica: «quina forma deu haver ciutat vella o be edificada" ". Fa servir repetidament el mot quarter per a anomenar cada una d'aquestes quatre parts en què és dividida la ciutat als efectes administratius ${ }^{62}$. Això no obstant, Eiximenis no va inventar res, sinó que es va fer ressò de la realitat del moment, ja que trobem documentada l'existència dels quarters a Cervera a partir del $1331^{\text {"." }}$, data del privilegi

(11) Si ens estenem en l'aparició i la delimitació dels quarters, és perqué tota la informació de qué disposem per al nostre treball apareix classificada i modelada per aquesta mena de barris. En un principi això podria distorsionar l'estudi de la distribució social de l'espai, ja que partiriem d'una distribució fixada a priori i de manera artificial, amb finalitats, no ho oblidem, purament administratives. Per evitar aquesta distorsió hem hagut de recórrer a precisar al màxim tot incloent l'anàlisi per carrers i no solament per quarters. Això no obstant, les declaracions dels veïns apareixen ben classificades per quarters $i$, per tant, el nostre treball no podrà sostreure's del tot a aquest condicionant previ imposat per la documentació emprada.

(1) Segons ho pregona el mateix Eiximenis, referint-se a les ciutats catalanes, indica que: "per consegüent la ciutat aquella hauria quatre quartons principals, ço) es, quatre parts; e cascuna part podria haver plaça gran e bella, e en cascuna part podria estar qualque notable gent especial».

62 Francesc Eiximinis (Selecció i edició d'Albert Hauf), Lo Crestià, Barcelona, 1983, pp. 188 (esp. els capítols $11,12,30,131,139$ i 152 del Dotzè).

"1 AHCC Pergamins 29, 1331 setembre 13; Publicat per Max Turuli. Rubinat et 
concedit per Alfons III el Benigne amb la intenció de canviar el sistema d'elecció en el règim municipal cerverí ${ }^{\text {in. }}$.

En la documentació posterior, pertanyent als anys 1332 i 1333, s'hi utilitza constantment el nom de quarters en català " $\mathrm{i}$ «quarterii» en llatí en els formulismes necessaris quan cal elegir un nou Consell. " ${ }^{\text {ct }}$ D'aquesta manera, tant a Cervera com a Tàrrega, la vila resta idealment dividida en quatre parts,

Montse Canela GarayoA, Tres pergamins en català del segle XIV a l'AHCC, "Butlletí de Dialectologia Nordoccidental», 4 (Fondarella, 1985).

(*) En aquest sentit és ben clar el pergamí a què ens referim: "(...) que sie feyta enaxi que feyta partió de la dita vila en IIII parts (...)".

(s) AHCC, Consells 1332-133310 v.

or AHCC, Consells 1332-1333 44 v. També a Tàrrega, en aquest cas Pere III el Cerimoniós, es va instaurar el 1342 el sistema dels quarters com a forma per a elegir el Consell de la vila, substituint l'elecció per «mans» i «jurats» (Arxiu Històric Comarcal de Tàrrega (=AHCT) Pergamins 38, bossa 1; Llibre de Privilegis III 54r). Però aquesta partició tan clara en quarters de Cervera $i$ Tàrrega no l'hem trobada documentada com a norma general en d'altres llocs (Barcelona i Lleida també van ser dividides administrativament en quarters, a més a més de parròquies; però aquesta partició ideal de la vila no va tenir aplicació a l'hora de conformar políticament el Consell municipal. Cf.: Francesc Carriras y CANDI, Geografia General de Catalunya. Ciutat de Barcelona, Barcelona, s/d; vid. també Maria Teresa VinYolis I VIDAL, La vida quotidiana a Barcelona vers 1400, Barcelona, 1985, pp. 43-44; i per a Lleida, Rafael GRAS Y DE ESTEVA, La Paberia de Lérida. Notas sobre la antigua organización municipal de la ciudad. 1149-17()7, Lleida, 19()9). Va ser molt usual clegir cls càrrecs municipals atenent l'origen social dels Candidats. Les tres «mans", també teoritzades en Eiximenis (EIXIMFNIS, Dotzè, i Regiment), eren el patró a partir del qual hom procedia a nomenaments i designacions. Al final de segle XIII Tarragona comptà, durant un quant temps, amb quatre jurats, la qual cosa sembla un indici que l'elecció s'havia pogut celebrar per circumscripcions electorals, extrem, però, que no s'explicita en absolut (Josep Maria RFCASINS, La ciutat de 'Tarragona, II, Barcelona, 1975, p. 177). La reinstauració de la Paeria a Balaguer el 1311 també ens aboca a pensar que existiren els quarters, ja què el Consell era format per quatre paers i vint consellers. Amb la insaculació del 15()1 s'introduí el sistema de mans, però abans tampoc no es parla expressament de quarters (Pere SanahliJa, Histöria de la ciutat de Balagker, Barcelona, 1965, pp. 261-262; recentment, Max TuRUI.I. RuBINAT, El règim municipal al Comtat d'Urgell. De la "Universitas» a la "Paheria»: el govern de la ciutat de Balaguer a la baixa edat mitjana, "F:I Comtat d'Urgell», Lleida, 1993). On la divisió administrativa ciutadana apareix forşa clara és a Lleida. Hi ha senyals que per 1313-1314 l'örgan executiu municipal cl formaven quatre paers, procedents de les diferents parròquies: dos de la de Sant Joan, un de Santa Magdalena i un altre de Sant Llorenç. La reforma del 1386 introdui modificacions on es contemplen les "mans» i també les parròquies, que havien augmentat en cinc, amb Sant Marti i Sant Andreu (GRAS Y DE Estiva, La Paberia de Lérida, pp. 32-34). En aquest cas tampoc no es parla per a res de quarters, però en canvi sí que s'evidencia una partició de l'espai amb intencionalitat administrativa. De fet, aquest tipus de divisió territorial interna és conseqüència de l'estructura institucional de què gaudeix un municipi. La forma de Paeria comporta l'elecciós per circumscripcions, la qual cosa fou caracteristica de la Catalunya Nova, i en especial a Cervera, Tàrrega, Lleida, Balaguer i Agramunt. 
que són clarament un instrument d'intervenció administrativa, ja què totes les eleccions dels més variats càrrecs i responsabilitats es fan seguint el criteri de representativitat per quarters.

Certament és difícil de proposar quins van ser els límits i l'abast de cadascun dels quarters. La documentació escrita conservada a l'arxiu no és gaire explícita en aquest sentit. Això no obstant, i considerant les referències indirectes de les fonts a l'abast, llencem aquesta partició hipotètica que caldrà verificar oportunament.

El quarter de Cap Corral és el que sembla més definit. En una ocasió s'anuncia que va des "del Portal Mitjà amunt». El quarter de Montserè també té poques variants. Sovint trobem «Montserè» i res més; algunes altres vegades va acompanyat "de les vals» $i$ en una altra ocasió se'ns diu que va "de les vals e de Monserè ab son compliment». El quarter de la Plaça és delimitat d'aquesta manera: «item al segon quarter, zo es saber del Portal Mitjà tro al cantó d'en [ ] za Guàrdia». De tots, és el més especificat, potser perquè és el més cèntric $i$, per tant, envoltat d'edificacions, el que té més punts de referència. En un altra ocasió trobem, referit al mateix quarter, «in quarterio intus portale medianum dicte ville de platea et ville nove et ceterorum vicorum dicte quarterii». L'últim quarter és el que presenta més noms diferents al llarg del text, i el delimita així: «item del quart quarter, zo és del carrer de Barchinona e de l'abeurador ab sos drets»; malgrat tot, el nom que rep en la part en llatí és el de "Ceboleria», i s'hi afegeix: «dicto quarterii de la ceboleria et de vico de Barchinona e de l'abeurador»" ${ }^{6}$.

Però la denominació més usual fou la de Montserè, Plaça, Framenors i Cap Corral.

Malgrat el nostre deficitari coneixement dels límits de cada quarter, sembla lógic que els contemporanis tingueren present amb precisió a quina unitat pertanyien. La congregació dels cinquanta prohoms electors o compromissaris de cada quarter per a triar consellers i paers, o bé la reunió dels d'una circumscripció per a escollir determinats representants, obliga a saber a quin quarter es pertany. També a efectes fiscals (les talles les plegava un col.lector diferent a cada quarter) la delimitació devia ajudar a la conscienciació. Un altre factor que incidí en aquest sentit fou l'organització del Manifest en la taxació dels béns dels veïns. Classificats per quarters, els béns declarats apareixen subdividits en carrers. De manera que, si abans havíem intentat fixar els quarters per punts de referència, ara podem fer-ho atenent els carrers i zones que contempla el Manifest. Tot això, és cert, implica que l'autoritat municipal sí que tenia clar fins on arribava cada quarter; un altra cosa diferent és la percepció del fenomen per part del poble.

6: AHCC, Consells 13.32-133329 v, 44 r-v. 
La confecció d'un plànol de la Cervera medieval ${ }^{\text {ch }}$ requereix algunes observacions ".".

Considerem el Portal de Vilanova com el mateix que el Portal Mitjà. Fins en aquest punt l'espai devia ser més densament construït identificant-se amb la vila closa de segles anteriors. Més enllà de Portal Mitjà l'espai era ample i poc edificat, com ho prova que s'hi instal-lessin monjos agustinians, a la recerca sempre de llocs apartats i tranquils. Ni que la situació canviés a la segona meitat del segle XIV, i sobretot en refer-se la muralla de Pere III, és facil que perdurés la denominació popular i també la delimitació del quarter. De fet, el 1356 es parla de fora i dins de Portal de Vilanova, i el 1.382 de fora de Vilanova i de dins de Portal Mitjà, que de fet es complementen i probablement és exactament el mateix.

Pot dir-se que s'aprecia una lleu diferència entre la limitació del Cap Corral del 1.332 i de després. Primer es deia «del Portal Mitjà amunt», i a la segona meitat de segle el quarter de la Plaça surt ja del Portal de Vilanova. No obstant això, un fragment del 1.332 que ja hem reproduit dóna peu a reflexionar sobre els límits del quarter de la Plaça. Segons aquell fragment aplega «intus portale medianum dicte ville de Platea et ville nove et ceterorum vicorum dicte quarterii»" "Quin sentit tindria repetir la menció al Portal Mitjà i a la Vilanova? Se'ns acudeix pensar si per "ville nove et ceterorum vicorum» hom no es refereix al creixement cap a Framenors; però acpuesta hipotesi perd pes quan ens adonem que el carrer de Barcelona, per exemple, pertany indubtablement a Framenors. Per tant, continuem pensant que la "ville nove» a què es refereix és el creixement lineal del carrer Major amb la direcció vers el Cap Corral.

El quarter de Montserè compta amb el cap del carrer de Barcelona. Ja que el fossar -i per aquest entenem l'actual carrer Sebolleria- formava part de Framenors, semblava coherent que el cap de carrer de Barcelona s'identifiqués amb el que avui és carrer de Montserè, que no és ni més ni menys que la continuació del carrer de Barcelona que arrenca de Sant Cristofol i puja tota la costa passant per darrera de Santa Maria. De fee és una apreciació perfectament susceptible de canvi.

Com podem veure hi ha un gran nombre de carrers no identificats que, si

in Els carrers i les zones pertanyents a caldat quarter al llarg del segle XIV, segons cels volums del Mannifest, sion els yue especificuem en un quadre a part al final del text. Amb aquesta relacio dassificada i les referencies esmentades podem claborar un planol anb una particio aproximada dels quarters, que no variarit mole del que ja vatrem confecoionar fia un

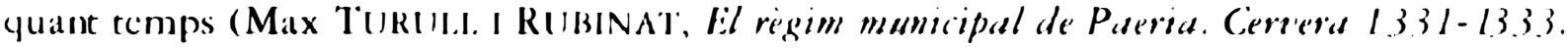
Dinaimiac social i politicas, Llevida, 1986, pp. 159).

(i) Vid. Figura 2, Figura 3, Figura 4 i ligura 5 (mapes $A, B$, (.).

"AHCC, Consclls 13.32-1333 44 v. 
ho fossin, ajudarien a limitar molt millor els quarters. Particularment ambigu ens queda el primer tram del carrer Major venint de Santa Anna, i la zona de la costa de Sant Cristòfol, carrer de Sant Bernat. La part paral-lela al carrer Major a sol ixent pot considerar-se del quarter de la Plaça i també la de Ponent. En aquesta darrera hem identificat el carrer de l'Hospital o de Sant Joan amb l'actual carrer de Sabater, o bé el començament del d'Estudivell, per la proximitat amb la casa que fou hospital de l'Orde de Sant Joan.

Efectivament, no hem aconseguit fixar amb nitidesa els quarters, $i$ en especial les parts de contacte entre si. Probablement un estudi continuat dels volums del Manifest dels segles XV i XVI oferiria nova llum a la qüestió.

La delimitació dels quarters no es va fer de manera arbitrària, -sinó que responia a una lògica o estructura subjacent. Duran i Sanpere ha parlat de l'expansió de dues viles noves: l'una per influència de Framenors i vora l'horta, i l'altra per la pressió del convent de Sant Domènec. Igualment ha posat de manifest la idea de l'existència de tres nuclis militars-defensius: el Castell $\mathrm{i}$ l'àrea de Montserè, la vila vella fins al Portal de Santa Maria i el Cap Corral amb muralla pròpia". En el fons, aquestes unitats "de creixement» no s'allunyen tant del que foren els quarters. Montserè agrupava les edificacions més properes al Castell i també la vall de Sant Domènec; la Plaça comprenia el que havia estat vila closa; Framenors, el creixement a la vora del carrer de Barcelona i cap a la vila nova de Sant Francesc; i Cap Corral, el nucli dispers que avançava més enllà de cert punt del carrer Major.

De fet, aquest de Cap Corral era el quarter amb més personalitat. Fins que no comptà amb muralla pròpia el Cap Corral eren les construccions bastides fora el nucli emmurallat, en els ravals que seguien les vies de comunicació, cap a Agramunt i cap a les Oluges. Prova d'aquesta particularitat pot ser el cas del 1377 , quan el Rei donà dret als veïns d'aquella zona a disposar de sis-centes lliures dels ingressos de les imposicions municipals per tal de finançar l'obra del raval de Sant Antoni "2.

Un cas a part és el del llogaret de Vergós de la Ribera, els veïns del qual, a pocs quilòmetres de Cervera, eren comptabilitzats, a tots els efectes, dins del quarter de Framenors.

Finalment, una altra zona diferenciada era el call jueu. Aquesta comunitat, com era norma, vivia segregada del col-lectiu cristià, $i$ això es reflectia també en l'estructura urbanística. Poca cosa podem afegir sobre la localització del call que no l'hagi publicada Duran i Sanpere ". L'existència d'una comunitat jueva a Cervera es remunta com a mínim al segle XIII moment en el qual

"Agustí Duran i Sanpere (Ramon Turull Barguŕs, Ed.), Llibre de Cervera, Tàrrega, 1972; Barcelona, 1977², pp. 33, 41, 14-15.

AHCC, Consells 137723 r, 27 r.

7 Duran i Sanpere, Op. cit., pp. 345-384. 
Jaume II autoritzava l'ampliació dels límits del call jueu. Però sembla que aquest creixement no fou efectiu fins el regnat d'Alfons III qui el 1328 concedia un privilegi on precisava els detalls de l'ampliació ${ }^{74}$. Amb aquesta, el call comptaria amb dos carrers: el call sobirà (el més antic) i el call jussà, o carrer del vent, que feia cantonada a la plaça de l'Om, o de Sant Miquel.

Aquest creixement es va traduir, segons Rubió i Lluch ", en l'existència d'una escola de jueus ja l'any 1323 , encara que la seva col-laboració i creixement foren posteriors a aquesta data $\mathrm{i}$ anteriors al 1385 , moment en què coneixem un cens dels seients que tenia i el preu que costaven. Per tant, aquells dos carrers paral-lels, tancats en els extrems, formaven el Call jueu. Aquesta forma persistí al llarg del nostre període, tot i que en èpoques de crispació social -en especial el 1391 - fou necessària la intervenció reial per a garantir la propietat de les cases als jueus que les regentaven.

En la divisió administrativa en quarters, la ciutat hi és tractada com un tot homogeni i indiferenciat; però, davant la manca d'altres dades amb què ho puguem contrastar, la seva aproximació en les relacions entre espai i societat és l'única que tenim i, per tant, en serà la base metodològica sobre la qual podrem edificar la nostra visió sobre l'espai ciutadà, tant respecte dels quarters com dels carrers.

\section{DIFERENCIACIÓ SOCIAL I FORMACIÓ D'UNA ÈLIT DIRIGENT: DESIGUALTAT SOCIAL I PATRICIAT URBÀ EMERGENT}

Com a resultat de l'anomenat "debat sobre la diferenciació social»", va delinear-se un model teòric d'estudi que, nascut i desenvolupat en el si dels estudis sobre la pagesia (Peasant Studies), ha anat prenent cos com a vertader laboratori productor d'aportacions crucials per a la història social, sobretot per a èpoques pre-industrials.

14 Duran i Sanperf, Llibre de Cervera, pp. 349-350.

"Antoni RUBIÓ I LI.UCH, Notes sobre la ciència oriental a Catalunya en el XVIè segle. "Estudis Universitaris Catalans», III (1909), pp. 390. ACA, C, reg. 182, fol. 9 r.

76 Per al plantejament complet del debat a l'entorn de la diferenciació social, vid: Teodor SHanin, La clase incómoda. Sociologia política del campesinado en una sociedad en desarrollo (Rusia 1910-1925), Madrid, 1983, pp. 75-96. Generalitzant podem destriar dues posicions enfrontades: d'una banda, els economistes neoclàssics i marxistes (com a exemple,vid. Vladimir Ilich LENIN, El desarrollo del capitalismo en Rusia. El proceso de la formación de un mercado interior para la gran industria, Barcelona, 1974) i, d'una altra, els neopopulistes (com a exemple, vid. Alexander Vasilievich CHAYANOV, La organización de la unidad económica campesina, Buenos Aires, 1985). 
Com a aportació essencial, ens ha arribat l'esmentat model segons el qual hi havia quatre tipus bàsics de mobilitat camperola que podien expressar-se en dues grans escales de canvi: el canvi agregat, expressant una millora o d'un empobriment general de la posició sòcio-econòmica d'una societat camperola considerada globalment, i els processos de diferenciació, expressant canvis en la diferenciació socio-econòmica interna de la societat ".

Fent un petit salt metodològic, creiem encertat d'aprofitar aquests estris estadístics en tant que, mentre van ésser pensats per a l'estudi de la pagesia, els emprearem en l'estudi d'una societat preindustrial i predominantment agrícola ${ }^{\text {s }}$.

De l'observació dels resultats d'aquest model, podem dir que, a grans trets, Cervera presenta, d'una banda, un comportament per quarters respecte del canvi agregat: Cap Corral i la Plaça -amb la petita excepció de la riquesa moble d'aquest darrer- tenen una tendència ascendent, mentre que Montserè la té descendent; en canvi, respecte a la diferenciació pot apreciar-se un comportament més temporal i no pas espacial: els quarters abastats entre 1340-1370 (Cap Corral i Plaça) tendeixen a la polarització, mentre que els situats entre 1370)-1380 se'n van vers la nivellació.

És significatiu observar el pes determinant en el comportament de la riquesa immoble, extrem més que evident al quarter de la Plaça, el 1.382, on el canvi agregat descendent de la riquesa moble condiciona, encara més si és possible, l'augment fort del total.

Tractant d'interpretar aquestes dades sembla plausible un tipus d'explicació de la següent mena.

Mentre el canvi agregat ascendent i la polarització en el quarter de Cap Corral semblen respondre a alguna mena de moviment migratori d'individus amb alguna riquesa, les mateixes característiques patents a la Plaça semblen indicar, en canvi, una progressiva absorció de la riquesa del sector primari en mans del terciari; ben bé podriem parlar del fet que la pagesia que habitava la Plaça es veu desplaçada vers Cap Corral en el període 1340-1370. D'altra banda, el quarter de Cap Corral en el període 1366-1382, el canvi agregat ascendent general de la riquesa $\mathrm{i}$, en especial, de la immoble en contraposició de la moble que descendeix i l'anivellació social sembla indicar una estabilització del sector terciari en el predomini després d'esbandir la pagesia i una tendència

En termes estadístics, un increment o una disminució de la mitjana (Md) mesurari els canvis agregats, mentre que la desviació estàndard o típica (S) mesurarà els processos de diferenciació; creixents amb la polarització i decreixents amb l'anivellació (SHANIN, La clase incómoda, pp. 81-82).

' Una extrapolació semblant de mètode ja havia estat practicada per Rodncy HILTON, Razones de la desigualdad entre los campesinos medievales, in Conflicto de clases y crisis del feudalismo, Barcelona, 1988, pp. 51-70). 
econòmica vers el rendisme. En el mateix període i en el quarter de Montserè, es produeix un canvi agregat descendent i una anivellació social que semblen parlar d'una pauperització del quarter i àdhuc d'un bescanvi de població entre aquest quarter i la Plaça: la pagesia de la Plaça, que en el primer període semblava dirigir-se envers Cap Corral, ara ve a Montserè i els membres del sector terciari (en especial, les professions liberals) de Montserè se'n van cap a la Plaça.

\section{III.1. La riquesa social de Cervera al segle XIV. Una aproximació general "}

Per tal d'establir una primera aproximació a la riquesa social de la vila de Cervera a mitjan segle XIV, cal l'observació de dues variables essencials: manifestants i volum de la riquesa; la mesura estadística que posa en relació ambdós caràcters és, sens dubte, la mitjana aritmètica ${ }^{\text {"0 }}$.

L'observació d'aquesta mesura estadística ens palesa un diferent comportament temporal: d'una banda, mentre que fins a mitjan dècada dels seixanta hi ha un creixement, d'una altra banda, a l'època que abasta des de mitjan anys seixanta fins als vuitanta hi ha una devallada. Encara que és força significatiu el comportament divergent dels diferents tipus de riquesa en el quarter de la Plaça en la segona època esmentada: mentre que la riquesa immoble continua creixent, la moble s'encara vers la devallada.

A què responen aquests comportaments diferenciats de les mitjanes?

En un principi caldria rebutjar qualsevol explicació que fes referència a la interferència del frau fiscal: el control directe i immediat dels prohoms taxadors -empesos evidentment no pas per un zel moral-fiscal, sinó per l'interès egoista de saber que allò que hom pugui amagar revertirà posteriorment en la quantitat adjudicada a cadascú per al pagament de l'impost corresponenthauria reduit aquest a mínims.

L'altre factor econòmic, però, que podria ésser distorsionador és, sens dubte, la possibilitat que una mateixa riquesa hagués estat valorada a preus diferents: depenent de si els preus estaven en una situació inflacionista o bé

19 Vid. Figura 6 (La riquesa a Cervera al segle xIv. Aproximació estadística).

80 Cal, però, parar esment en cóm es presenta la mesura estadística de la mitjana: l'elevadíssim grau de dispersió dels valors ( caràcter visible en els valors de les desviacions típiques i els coeficients de variació ) ens demostra l'extremada manca de representativitat de les mitjanes de riquesa en cadascun dels quarters i al llarg de tot el període estudiat. 
deflacionista els resultats en sortirien modificats. Sobre aquest punt és inevitable caure en els tòpics, ens manca una investigació que estableixi una sèrie continuada de preus per a l'àmbit català en aquesta època $i$, a més, la nostra font-que, a primera vista, podria semblar prometedora- no ofereix cap tipus de fiabilitat, ja que és, en excés, qualitativa en les descripcions de les possessions $i$ béns $i$ manca també un criteri unificador entre preus $i$ béns.

Fiant-nos de les extrapolacions acostumades, com la de Vilar ${ }^{81}$, sobre les sèries de preus aragoneses $\mathrm{i}$ valencianes d' Hamilton ${ }^{\text {s2 }}$, cal mantenir, com a hipòtesi per a Catalunya, l'existència, del 1350 al 1380 , d'una espiral inflacionista i que, de moment, devia amagar els efectes econòmics de la baixada demogràfica. A partir d'aquesta consideració, els comportaments de les mitjanes i del nombre de manifestants ens palesarien l'existència, durant aquest període, d'una devallada econòmica general a Cervera que, als quarters de Cap Corral i la Plaça, devia anar vinculada a una baixada demogràfica, mentre que, al quarter de Montserè, hi devia haver un creixement demogràfic. Cal palesar, també i d'altra banda, que aquesta explicació sembla la més versemblant si atenem a un simple raonament contrafactual: només una davallada econòmica general pot explicar, en una situació inflacionista, el comportament diferencial de les riqueses immoble i moble en el quarter de la Plaça durant el període 1366-1382; perquè, si haguéssim de recórrer a la contrahipòtesi deflacionista per als preus, ens resultaria difícil d'explicar com és possible que només la riquesa moble d'un sol quarter estigui en davallada econòmica en un context general (d'ambdós tipus de riquesa i de tots els quarters, inclosa la riquesa immoble del mateix quarter) de creixement econòmic.

Un altre caràcter que igualment destaca és l'aclaparador pes específic de la riquesa immoble en tots i cadascun dels quarters i al llarg de tot el període -en cap moment la riquesa immoble no deixa de representar, en proporció, menys de les tres quartes parts de la riquesa total-.

Si bé fins ara hem anat considerant el factor riquesa, ara farem un petit repàs al factor humà, als manifestants.

Des d'un punt de vista estructural o, si voleu, estàtic, podem dir que, en general, a Cervera hi havia dues estructures diferenciades: d'una banda, un

n1 Pierre VILAR, El declive catalán de la Baja Edad Media. Hipótesis sobre su cronología, in Crecimiento y desarrollo. Economia e historia. Reflexiones sobre el caso español; Barcelona, 198(14, pp. 252-331, esp. p. 278.); Pierre VILAR, Catalunya dins l'Espanya moderna. Recerques sobre els fonaments economics de les estructures nacionals, Barcelona, 1986', vol. II, p. 174).

*.2 Earl J. Hamilton, Money, prices and wages in Aragon, Valencia and Navarra (1.351-1400), Cambridge, 1936, p. 185. 
general predomini del sector primari als quarters de Cap Corral, Montserè i Framenors i que, a més, no es va alterar gaire amb el pas dels anys (tres quartes parts dels manifestants són del sector primari arreu); i, d'una altra banda, el sol quarter de la Plaça té una estructura, encaren que també bàsicament primària (un cinquanta per cent de la població), que va encarada vers el terciari, la qual cosa sembla lògica si considerem que el quarter de la Plaça era el centre-vila i aglomerava tots els serveis $\mathrm{i}$ el comerç.

Des d'un punt de vista evolutiu, podem veure com hi ha una tendència general vers l'especialització a mb el pas del temps: el quarter de Montserè i Cap Corral s'encara vers la manufactura, mentre que la Plaça i, en menor mesura, Cap Corral van cap al terciari. Tal i com ho veiem, doncs, és el sector terciari aquell que marca la diferència i, si l'estudiem més de prop, veurem com a Cap Corral i la Plaça aquells qui eren comerciants deriven vers les professions liberals i, en canvi, a Montserè hi ha el procés invers: són les professions liberals les que es canvien al comerç.

\section{III.2. La distribució de la riquesa: la desigualtat social i el seu grau ${ }^{\text {" }}$}

En agrupar conjuntament el Manifest cerverí béns i persones, ens permetrà entreveure cóm es distribueix la riquesa dins de l'escala social de Cervera; podrem, en certa manera, tenir una visió aproximada de com els cerverins gestionaven els seus patrimonis i com repartien, deliberadament o sota la pressió de les necessitats quotidianes, les seves inversions.

Per tal d'estudiar la distribució de la riquesa social ens servirem de dues eines estadístiques: d'una banda, la corba de Lorenz ${ }^{{ }^{*} 1} \mathrm{i}$, d'una altra, la corba de

81 Vid. Figura 6, Figura 7 (La distribució de la riçuesa: cl grau de desigualtat social. Dades estadístiques de les corbes de Pareto).

*. L'ús de la corba de Lorenz i de l'índex de Gini pretenen evidenciar la concentració de la riquesa, però mentre que la primera ho fa qualitativament el segon ho fa quantitativament. Aquest índex va de () a l; mentre la diagonal del quadrat és la línia d'equidistribució $\mathrm{i}$ equival a l'índex de Gini igual a zero, això significa que cadascun dels centils de la població té exactament l'u per cent de la riquesa total, la qual és, doncs, perfectament distribuïda; en canvi, quan l'índex s'atansa a $u$, indica que un sol centil de la població posseeix tota la riquesa. Hem traçat les corbes de Lorenz que il lustren la relació entre els centils acumulats de la població i els centils acumulats de fortuna que posseeixen; la relació entre corba de Lorenz i índex de Gini és clara; el valor de l'índex de Gini és exactament l'àrea de la superfície limitada per la diagonal del quadrat i per la corba de concentració, dividida aquesta superfície per l'àrea del triangle que té de costat aquella diagonal. 
Pareto ${ }^{\text {s) }}$. Ambdues, però, acompanyades dels seus estàndards numèrics: l'índex de Gini i el pendent de la recta de regressió.

De l'observació dels índexs de Gini i de les corbes de Lorenz en traurem, i així ho presentarem, consideracions de dues classes: d'una banda, unes consideracions de caire estàtic o estructural de les quals, tant l'índex de Gini quantitativament com les corbes de Lorenz qualitativament, treuen o demostren lliçons semblants o iguals, mentre que, d'una altra banda, hi haurà una visió dinàmica o genètica en què índexs de Gini i corbes de Lorenz ens oferiran lliçons de caire diferent precisament perquè el caràcter qualitatiu de les corbes ens fa apreciar fenòmens que els índexs obviarien.

A nivell estàtic $i$ on coincideixen corbes $i$ índexs, veiem dues constants: la riquesa moble sempre i en cadascun dels quarters és més concentrada que la immoble i la total; la riquesa immoble experimenta, entre el període 13661.382, una redistribució general.

L'explicació del primer fenomen sembla clar que cal vincular-la al fet que la riquesa moble representa precisament el tipus de riquesa diferencial perquè, d'una banda, per a les classes socials superiors significa el luxe en la llar i, d'una altra banda, perquè, per a les classes o els estrats sòcio-professionals actius implicats en la manufactura i el comerç -que normalment coincideixen amb els superiors- el capital mòbil o circulant n'és el fonament de la inversió: és el numerari fresc que s'inverteix en la compra de productes per a llur revenda $i$ també és l'instrumental artesanal dels obradors menestrals.

s' I.a corba de Pareto és un senzill model economètric fonamentat en una regressió que pretén evidenciar la desigualtat en la distribució de la ricuesa i que, a través del pendent calculat de la regressió -que és l'clasticitat de la funcio, perquic és una funció potencialo exponencial: cal entendre per elasticitat d'una funció acyucll parametre que expressa el perecentatge de variacio de la variable dependent quan la independent augmenta un u per cent ( I \%), sempre cuecens referim a funcions exponencials- explical el porgate o decreixement relatiu del nombre de persones a mesura que la ricpuesa val alugmentant, el cual nombre d'individus és, cada vegada, menor i disminucix proporcional ment al patrimoni, la cual cosa cal interpretar com el fet cue la facilitat de transició d'una classe de riquesa a una de més alta creix en proporció a la riquesa que hom té. En tant que regressio, la corba de Pareto cal acompanyar-la de tres clements diferents: la constant, yue ens situa a yuin nivell cal ubicar la recta de regressió obtinguda; el coeficient de correlació, que ens mesura qualitativament la intensitat de relació entre les variables, com més proper i més alt sigui el valor -én aquest cas, com que totes les regressions són negatives, el valor màxim serial $1-$ el lligam és més fort $i$, finalment, el coeficient de determinació, que ens mesural quantitativament la intensitat de relacio entre les variables; quan el valor s'aproxima a u vol dir que no hi hat errors o residus estadistics i que, per tant, hi ha una dependencia estadistica perfectat i que totes les variacions de la variable dependent les explica la independent $i$, yuan s'aproxima a $z$ ero, significa que hi ha independencial estadistica o que el model és inadequat $i$ que, per tant, poyues o cap de les variacions de la variable dependent no són explicades per la independent. 
El segon fenomen, en canvi, sembla que cal relacionar-lo amb una certa tendència general en el període vers la reconversió de riquesa immoble en riquesa moble que entra en el circuit econòmic sota la forma de capital comercial i manufacturer.

A nivell dinàmic, els índexs de Gini ens ofereixen dues lliçons diferenciades:

1) durant el període 134()-1.366, hi ha dos comportaments completament diferents dels quarters de Cap Corral i de la Plaça: mentre que el primer tendeix a la redistribució general de riquesa, el segon es dirigeix vers una concentració general;

2) durant el període 1.366-1.382, ambdós quarters de la Plaça i Montserè presenten comportaments idèntics entre si: la riquesa immoble i la total tendeixen a la redistribució, mentre que la moble es concentra.

L'explicació d'aquests fenòmens és complexa, però sembla que queden clares aproximadament les següents línies: el primer fenomen sembla obeir a una tendència econòmica general vers el rendisme ja que els capitals dels comerciants principalment es dirigeixen a mans de les professions liberals que atresoren la riquesa en general; en canvi, el segon fenomen sembla anar lligat, d'una banda $i$ al quarter de la Plaça, al fee que la riquesa de la pagesia s'inverteix en general en la manufactura $i$, d'una altra banda i al quarter de Montsere, al fet que les professions liberals inverteixen els seus capitals en la manufactura i el comerş.

També a nivell dinàmic, les corbes de Lorenz ens permeten precisar aquestes afirmacions. La redistribució general de la riquesa en el quarter de Cap Corral en el primer període prové d'una cessió de riquesa dels estrats socials superiors - dels més rics-vers la resta del quarter; en canvi, la concentració del quarter de la Plaşa cal vincular-la a una cascada en sentit invers, des dels esglaons inferiors de la societat vers els immediatament superiors. La redistribució de la riquesa immoble i total en els quarters de la Plaça i Montserè en el segon període va lligada al fet que els estrats socials superiors cedeixen llur riquesa a la resta $\mathrm{i}$, en canvi, la concentraciós de la ricquesa moble prové igualment d'una cascada inversa dels inferiors sobre els immediatament superiors.

Tractant d'articular una explicació global a aquests fenomens ens sembla clar que cal atribuir-los a un cicle de crisi economica que abastaria, si fa no fa, des de 1340 a 1.365 i que veuria com la riquesa social s'encamina vers el rendisme; i, en canvi, de 1365 a $138($ ) veuríem una represa economica caracteritzada per una tendència a la inversió sobretot manufacturera -o artesanal-i comercial, en segon terme i que segurament aniria vinculada a la manufactura perque serien els mateixos artesans els qui comercialitzarien directament els seus productes, s'hauria estatt produint el desplaşament dels intermediaris comercials per part de l'empenta artesanal-menestral. 
De l'observació de les corbes de Pareto i dels seus pendents en traurem sobretot una matisació del tipus de distribució de riquesa $i$, en especial, del grau en la desigualtat de la seva distribució.

Abans, però, d'entrar en el seu estudi cal que revisem la qualitat científica de les seves observacions i això ho farem mitjançant els coeficients de correlació i determinació.

D'una banda, les dades dels coeficients de correlació ens demostren, en situar-se a l'entorn de valors força elevats -la mitjana és de $-0,79-$, que ambdues variables es troben molt vinculades $i$, per tant, que qualitativament les nostres observacions són prou versemblants; d'altra banda, els coeficients de determinació ens demostren quantitativament que gairebé no hi ha residus estadístics -el seu valor mitjà és de $0,86-i$, per tant, que el nostre model economètric és força adequat $\mathrm{i}$ que les observacions que en puguem extreure són prou aproximades $\mathrm{i}$ reals.

De l'observació dels pendents es desprenen, des d'un punt de vista estàtic, dues constants: d'una banda, la riquesa immoble és sempre molt més desigual en la seva distribució i, per tant, és aquesta la que explica les diferències socials de riquesa en profunditat (menys habitants controlen molta més riquesa) i, d'una altra, la riquesa moble sempre és molt menys desigualment distribuïda i, per tant, aquesta no és gaire significativa en explicar les diferències de riquesa social (molts més habitants controlen menys riquesa).

Dinàmicament, el període 1340-1.365 veu crèixer la desigualtat en general als quarters de Cap Corral i la Plaça (les diferències entre rics i pobres es van engrandint) $i$, inversament, entre $1365-1380$ veiem com disminueix la desigualtat als quarters de la Plaça i Montserè (l'abisme que separava rics i pobres va escurçant-se $i$ hi ha una certa anivellació).

D'aquestes observacions, en vincular-les a les explicacions anteriors, semblen establir-se com a certs els següents extrems: la crisi econòmica i el rendisme consegüent en el primer període provoquen que els rics siguin cada cop més rics i, viceversa, els pobres; per tant, els efectes sòcioeconòmics de la crisi són, d'una banda, la paralització de l'economia i la pauperització dels estrats socials inferiors, i seran els econòmicament més dèbils els qui suportin el pes de la crisi; en canvi, la recuperació econòmica i el retorn de la inversió en el segon període sembla anar acompanyada del repartiment social dels seus efectes benèfics, és a dir, l'activitat manufacturera i comercial de l'artesanat significarà una elevació del nivell de vida -almenys els patrimonis així semblen indicar-ho- dels sectors socials mit$j$ jans $i$ inferiors. 


\section{III.3. La composició de la riquesa: l'estructura sòcio-econòmica ${ }^{\text {"n }}$}

Detectar el moviment general de l'economia cerverina del segle XIV ha estat el primer pas, però ara cal cercar les raons d'aquests que no podrien ésser unes altres que les forces productives; això significa, a grans trets, endinsar-se en la composició estructural d'aquesta riquesa social i els canvis que s'hi puguin veure ${ }^{\text {s? }}$.

En aquesta perspectiva, és evident que la comprensió d'aquestes estructures i llurs dinàmiques ha de donar-nos llum sobre les relacions socials de producció.

La consideració de la riquesa social com la suma de riqueses particulars planteja greus problemes: comparabilitat d'expressions monetàries, dobles oficis, debat al voltant d'activitats productives no remunerades, d'activitats remunerades i no productives, etc. Però, el fet de partir del criteri patrimonial, és a dir, de la propietat dels mitjans de producció, té l'avantatge de distingir clarament uns tipus d'ingressos i adscripcions socials l'expressió de les quals, encara que només sigui nominalment, constitueix sovint el signe millor percebut de prosperitats i d'estretors ${ }^{\text {Ag }}$.

L'estructura social i institucional domina la distribució de la riquesa, però, en domina igualment el moviment?' El moviment de les rendes no pot estudiarse separadament de l'estructura, de la qual en depén la sort dels individus i dels mitjans d'acció-reacció (pressió) de les classes. El moviment a curt termini,

ac Vid. les figures de la sèrie 9: Composició sòcio-professional i sócio-rècnica de la riquesa; Evolució comparativa de la distribució sectorial de manifestants; Riquesa toral i diagrames de barres explicatius. Figura 10: La composició técnica de la riquesa: dadés estadístiques de les regressions simples.

* Analíticament, considerem com a individualitzables tres aspectes d'ayuest conjunt: 1) la seva estructura tècnica, és a dir, detcctar lat importancia relativa d'un determinat tipus de riquesa ( cal remarcar que en aquest punt hem estat forsa elementals i només hem diferenciat -amb un criteri jurídic mínim-entre héns immobles i béns mobles); 2) l'estructura sòcio-professional, és a dir, veure com la riquesa es distribueixreparteix entre els tres sectors econòmics bàsics (primari, secundari i terciarı), peri fente menció especial en el terciari perquè és aquest el sector més diferenciat des d'un punt de vista professional; 3) l'estructura sòcio-tècnica, ambdós caràcters estructurals damunt dits (estructura tècnica i sócio-professional) s'han, necessàriament, d'entrelligar si pretenem explicar -almenys intentar-ho- a quines variables obeeixen els canvis socioeconòmics generals.

"*8 Sobre l'origen de semblants consideracions, vid. Pierre VII.AR, Crecimiento economico" y análisis histórico, in Crecimiento y desarrollo. Economia e Historia. Reflexiones sobre el casu español, Barcelona, 1980', pp. 17-10) 5, csp pp. 78-79. 
com el que presentem, sembla que és un bon laboratori, àdhuc per a la comprensió dels mecanismes a llarg termini ${ }^{\text {*g }}$.

Bàsicament, per a l'estudi d'aquestes estructures ens hem valgut de percentatges, excepció feta, però, de dues tècniques estadístico-gràfiques que hem cregut convenient introduir: per poder apreciar la dinàmica de l'estructura tècnica dependent dels nivells de riquesa, ens hem servit de regressions ${ }^{\%} \mathrm{i}$, en canvi, per a l'estudi de l'estructura sòcio-tècnica, hem preferit emprar diagrames triangulars ${ }^{\text {". }}$.

\section{III.3.1. L'estructura tècnica: el pes i la inèrcia inmobiliària}

Parlar de constants en història és un contrasentit -una contradictio in terminis-; aquest atemptat intel ·ectual contra la disciplina només és sostenible parlant a nivell de moviments de curta durada i de qüestions tan insensibles al canvi històric com el tipus de riquesa d'una societat predominantment agrícola com la pre-industrial europea-feudal rural i d'interior com el microcosmos cerverí medieval; tal i com era d'esperar la relació d'importància entre riquesa immoble i riquesa moble en la riquesa total de cadascun dels quarters es manté constant a favor de la immoble: aquesta representa invariablement un vuitanta per cent de la riquesa total, mentre que la resta $(20$ per cent) és moble; invariablement és una expressió excessivament dura perquè hi ha un marge de mobilitat a l'entorn d'un set per cent (positiu o negatiu), però que, en ésser

"Ny Vid. nota anterior, pp. 87-88.

"N Simplificant molts conceptes estadístico-matemàtics, podriem dir que el nostrc ús de la regressió consisteix bàsicament, a partir de la gradació ascendent dels membres de cada quarter segons llur riquesa total (variable independent ), a cercar la relació equacional amb el percentatge individualitzat d'immoble -tinguem present que, com que la riquesa moble és complementària de la immoble perquè ambdues plegades formen el cent per cent, hauria estat el mateix considerar la riquesa moble com a variable dependent - $i$, per tant, a partir del núvol de punts (diagrama de dispersió ) que es forma, aproximar-les, mitjançant l'ajust de mínims quadrats, a una recta de regressió. És evident que, per poder fer això, hem hagut de rebutjar aquells manifestants indigents totals.

"Els diagrames triangulars, com és sabut, classifiquen els individus segons un caràcter de tres modalitats $i$, evidentment, aquesta adequació al ternari qualitatiu és perfecta en el nostre cas, ja que ens implica tots tres sectors de l'activitat econòmica. Simplificant, cadascun dels costats d'un triangle equilàter, graduat de 0 a 100, representa una modalitatsector expressat en percentatges. La suma de totes tres modalitats de cada individu (quarter) és sempre igual a 100. Cada punt es defineix per tres coordenades en el gràfic: aquesta representació és l'equivalent d'un diagrama cartesià en R3. Per a una explicació més acurada i completa d'aquesta tècnica, vid. GrUPO CHADUle, Iniciación a los métodos, pp. 240243. 
mòbil a l'alça o a la baixa, l'únic que reflecteix és la immobilitat en la composició tècnica dels patrimonis.

De l'observació de les regressions simples fetes a partir de la diferència entre immoble i moble en percentatges de cadascun dels manifestants (sent ordenats de menor riquesa a major), és a dir, de l'estudi de la composició de la riquesa posada en relació amb la quantitat de riquesa absoluta, podem deduir que, en general, s'aprecia una tendència a la diversificació -representada per un augment de la component moble- en les capes més altes de l'estructura social, a excepció del quarter de la Plaça dels anys 1352 i 1366 . Aquest comportament diferent de la Plaça es pot entendre com una relativa tendència al rendisme en les esmentades capes socials.

El pes aclaparador i la inèrcia constant de la riquesa immoble expressen, encara que una mica grollerament, allò tan sabut, en contra de la tradició, que la ciutat -encara que sigui d'una importància mitjana com Cervera respecte de Catalunya- no era una illa en el mar rural, sinó més aviat la seva perllongació ${ }^{92}$.

\section{III.3.2. L'estructura sòcio-professional: del pes del primari a la mobilitat del terciari}

El pas dels patrimonis als grups socials és sempre decissiu en història social perquè sembla prou raonable $i$, fins a cert punt, demostrat que les relacions de propietat sobre els mitjans de producció condicionen les estructures socials i que, per tant, ambdues components són internament força vinculades.

En l'estudi social dels patrimonis, sembla obligat veure-hi -almenysdues característiques bàsiques: les proporcions de riquesa retinguda per cada grup social $i$, a més, quins nivells de riquesa acumulen aquests grups.

A nivell estàtic, podem dir que els sectors primari i terciari acumulen, per terme mitjà, el 90,65\% de la riquesa; però, sens dubte, la significació de la dada és que va acompanyada d'una relativament petita desviació típica $(s=3,75)$, la qual cosa vol significar que, mentre que la significació de cada sector per separat depén en grau extrem del lloc i de quan l'observem, primari i terciari arreu són prou estables en tant que sectors dominants i, a més, mentre

${ }^{2}$ Només les grans burgesies ciutadanes, com la barcelonina, podien permetre's el luxe de desvincular-se econòmicament de la terra en èpoques d'inestabilitat econòmica com la de crisi baixmedieval. Sobre la trajectòria en aquest sentit d'algunes famílies de mercaders catalans, vid. Joan Josep BUSQUETA I RIU, Sant Andreu del Palomar als segles XIII i XIV: un exemple per a l'estudi de les relacions ciutat-camp a la Barcelona de la baixa Edat Mitjana, Barcelona, 1991. 
que el sector secundari presenta una certa estabilitat, primari i terciari són mòbils, però entre ells.

Mentre que la preponderància, a nivell general, del primari $(x=52,44)$ acompanyada d'una forta inestabilitat depenent d'on i quan fem l'observació $(s=15,78)$ ens parla d'una societat que, en termes molt generals, es mou en una economia agrícola bàsicament, el pes del secundari $(x=9,34)$ amb una gran variabilitat $(s=3,75)$ ens indica que la manufactura era dèbil en el context econòmic $i$ que depenia, en gran mesura, de com actuessin a nivell econòmic la resta de sectors -sovint caldria veure artesans vinculats a la pagesia, ja com a simples propietaris agrícoles ja com a pagesos que, a estones, es dedicaven a la manufactura-.

Altrament, el sector d'un pes econòmic considerable $(x=38,21)$ i d'una gran inestabilitat ( $s=15,33)$, com és el terciari, ens faria sospitar l'existència d'unes fortes imbricacions amb la propietat pecuària; però, considerant el terciari internament, ressalta que estigués dominat, durant tot el període i en tots els quarters, per les professions liberals $(x=16,28 / s=9,83)$ i pels comerciants $(x=20,08 / s=8,30)$, però d'una manera fluctuant, la qual cosa només seria explicable per una versatilitat gran en els interessos de sector només explicable per possibles dobles interessos en dependència d'inversions rendistes (professions liberals) $i$ interessos comercials (comerciants). La resta, $i$ és significatiu, d'estrats del terciari fan un paper de convidats de pedra $\mathrm{i}$ testimonial, la qual cosa ens refermaria en el caràcter de centre-vila -petit, no cal dir-ho- de serveis i comercial, en contra de la possibilitat que podria haver significat la presència en massa d'elements de l'administració civil o de senyors feudals.

De l'observació dels valors de les mitjanes de riquesa de cada sector i en cada quarter i any, en destaca, encara que aquesta mesura no sigui potser la més adequada per a afirmar certes coses, l'extremada variabilitat en tots els nivells; l'atribució d'aquest fenomen sembla encarar-se vers els moviments de curta durada de l'economia; encara que no seria despreciable parar esment en uns punts -de poc pes explicatiu, però interessants-com: el pes elevadíssim de l'immoble en la configuració de les riqueses, fins a l'extrem -raonable, és clarque, per al sector primari, el seu pes és tan aclaparador com per a suposar-lo gairebé tot sencer; és a dir, seríem -sembla deduïble- davant d'una pagesia descapitalitzada que -segurament- devia dependre creditíciament d'uns altres sectors; la presència fcudal sembla purament eventual i tan mòbil com per a fer suposar que es tractava més aviat d'esporàdiques inversions immobiliàries d'uns quants elements amb tendències urbanícoles dels petits senyors de la rodalia i, finalment, la distància entre el terme mitjà de riquesa del terciari, en particular dels seus estrats potents (professions liberals i comerciants), i de la resta és tan gran com per a arribar a significar el seu moble sol la totalitat de la riquesa dels altres, és a dir, en qualsevol moment, molts comerciants i profes- 
sionals liberals podien oferir la compra de tot el que tenia un pagès o artesà.

Considerada l'estructura sòcio-professional des d'un punt de vista dinàmic, podem dir que, en general, s'observa una certa tendència vers l'especialització econòmica, sia del sector terciari o secundari; sense ànims d'excessiva generalització, sembla possible advertir una època daurada de creixement del terciari entorn del període 1340 -1.370 i una segona embranzida protagonitzada per l'artesanat entre 1370-1380. Cal, però, ésser cautes en fer aquesta generalització ja que, d'una banda, la manca de dades i, d'una altra, l'especificitat de cada quarter ens podrien modificar l'esquema presentat. Només a tall d'observació cal parar compte en la relativa estabilitat del quarter de Cap Corral, la progressiva especialització terciària del quarter de la Plaça (cal recordar que la Plaça era el quarter que ocupava el centre de la vila, s'hi acumulaven els serveis i allí habitaven els rics) i el comportament ambigu del quarter de Montserè, ja que si, d'una banda, té tendència a la ruralització, de l'altra sembla agrupar la manufactura de recent creació. L'obligada interconnexió entre artesanat i pagesia explicaria millor, potser, l'ambigüitat de Montserè.

Per tal de fer llum sobre les tendències apuntades més amunt, convé centrar-nos en el sector econòmic més viu i mòbil -el terciari-: mentre que els petits canvis de Cap Corral semblen correspondre més aviat a un moviment de la riquesa dintre del sector, ja que la riquesa dels comerciants sembla revertir en els subsectors més rendistes (professions liberals i feudals), a la Plaça, en canvi, els moviments intersectorials són insuficients per a explicar els canvis; en un primer moment (1352-1366) les professions liberals, en una clara tendència rendista, xuclen la riquesa dels comerciants, però, també i sobretot, reben riquesa de la pagesia $i$, en segon terme (1366-1382), sembla produir-se un fenomen canviant: creixen les professions liberals i també els comerciants sobretot a costa de la pagesia $\mathrm{i}$, finalment $\mathrm{i}$ com sempre-Montserè és un altre món-, allí són precisament les professions liberals les que cedeixen riquesa a la pagesia i l'artesanat.

Tot això vist en conjunt sembla confirmar la primera impressió: el període 1340-1370 correspon a una etapa de tendències rendistes $\mathrm{i}$ d'acaparació de riquesa per part de les professions liberals a costa de desmobilitzar la riquesa dels comerciants i d'una possible pauperització-proletarització de la pagesia (l'era d'or del rendisme?), mentre que el període $137($ )-1380) aniria vinculat més aviat a la recuperació inversionista en la manufactura ja per via de l'expropiació de la pagesia (Plaça) ja per mobilització de la riquesa acumulada per les professions liberals (Montserè) (l'era d'or de l'artesanat?).

Si observem aquests fenòmens a nivell de les mitjanes de riquesa, els plantejaments anteriors es perfilen molt més.

Mentre que en el primer període hi ha un creixement de la riquesa mitjana 
del terciari, en el segon és aquest mateix terciari el que davalla; si ens n'anem a l'observació intersectorial del terciari, les coses semblen clarificar-se més encara: el primer període correspon al creixement de les classes passives econòmicament (professions liberals i feudals) -clar síptoma rendista?-; en canvi, en el segon hi haurà un decreixement general, però accentuat en els feudals $\mathrm{i}$ professions liberals (inversió en la manufactura, mobilització econòmica dels recursos estancats) i els comerciants.

\section{III.3.3. L'estructura sòcio-tècnica: entre el rendisme immobiliari del terciari i la suposada inversió mobiliària de la manufactura}

Quan ens introduïm en l'estudi de la composició tècnica (immoble / moble) de la riquesa de cada sector econòmic, la imatge estàtica que en rebem és gairebé un calc de la sòcio-professional però ara traduïda a riquesa immoble: el pes d'aquesta és tan extraordinari que marca la preponderància d'un o altre sector $\mathrm{i}$ àdhuc d'un o altre subsector del terciari.

Cal fer, però, algunes matisacions: a nivell d'immoble les diferències que podria haver-hi entre pagesia i terciari a nivell general s'enfosqueixen per tal d'indicar-nos que també comerciants i professions liberals s'interessaven per les propietats territorials. En canvi, convé destacar que la riquesa moble -quantitativament poc important- té un comportament significatiu: la riquesa moble, en el primer període (1340-1370), roman en mans del primari, la qual cosa sembla voler dir que, en època de rendisme i proletarització de la pagesia. aquests devien rebre els seus salaris o els resultats de les seves rendes territorials en efectiu o en espècie, més aviat el primer; en el segon període (1370-1380) $\mathrm{h}$. ha un canvi: la riquesa moble passa ara a mans del terciari, els benefici: rendistes es concretaran en objectes de luxe domèstic $i$, d'altra banda, $e$ secundari invertirà principalment en béns immobles; reflex i pors d'èpoque: passades?

A Cervera -almenys això semblen indicar les nostres dades-, la propieta immobiliària, sia rural o urbana, va significar un factor plenament essencia entre mercaders i professions liberals i sembla que ulteriorment entre l'artesa nat; va haver-hi una progressiva concentració immobiliària i va ésser acaparad per aquests mateixos grups socials".

"Pel plantejament del problema del paper desenvolupat per la propictat immobilia ria a la base de la "primitiva» riquesa mercantil, vid. Rodney HII.TON, Algunos problemas propiedad urbana en la Edad Media, in Conflicto de clases y crisis del feudalismo, Barcelon 1988, pp. $91-105$, esp. p. 92. 


\section{III.4. La formació d'una èlit dirigent: el patriciat emergent com a oligarquia i grup de poder urbà "}

El marc jurídic que fixava l'accés al Consell s'havia regulat a partir i al voltant del privilegi reial de 1331 . El procés electiu a partir de circumscripcions geogràfiques va enterrar la pràctica d'una representació social a través de les tres «mans». Amb el nou sistema dels quarters o barris, no es garantia en absolut la representació política de tots els sectors socials, sinó que s'obria la possibilitat d'una rotació interna semblant a un règim de cooptació suavitzada. Jurídicament, el moment clau del procés electiu dels membres del Consell era la proclamació d'electors i la selecció de candidats. Els càrrecs finalment elegits

94 El tema, del que ara només n'oferim una síntesi, el desenvolupem completament, malgrat afegir ara algunes novetats de metodologia i plantejament, a TURUII., La configuració jurídica del municipi, pp. 587-619. Les dades sobre les que sustentem les nostres afirmacions poden veure's a Max TURUII. I RUBINA'T, Relació nominal per ordre alfabètic i cronològic de paers, consellers i electors de la Paeria de Cervera entre 13.31 i 1.395, "Miscel lainia Cerverina", 8 (Cervera, 1992), pp. 155-193, amb l'adscripcio professional dels càrrecs polítics esmentats. La concomitancia temattica s'explical pel fet que, mentre en l'obra primerament esmentada es té present tot el segle XIV sencer, l'abast cronoliogic del present treball, en canvi, es limita gairebé a la seva meitat central. Des d'un punt de vista heurístic, cal advertir de l'existència d'un déculage entre les dues fonts que ens ha calgut confrontar per abordar aquest capítol: la certesa i abundor de les dades de caràcter polític-extretes bàsicament dels Llibres de Consells de la Paeria- contrasta vivament amb la mancança o fragmentació de la informació fornida pel Manifest respecte a cadascun dels càrrecs municipals. Per bastir el present capitol, apart d'haver d'acceptar estoicament la relativa manca de dades, ha calgut lluitar contra el sempre recorrent i gran problema de tots aquells historiadors yue ens enfrontem amb documents serials de l'era pre-estadística com és l'homonímia dins d'unes matcixes famílies: lat solució escollidat hat estat, prenent com a base l'arrel filologica dels noms, el treball de crítical historrica consistent en la confront ació restrictiva al màxim (només s'han validat aquedls subjectes amb una certesal total d'identitat) de les diferents fonts disponibles que ens permetessin la identificació univoca dels subjectes. Les limitacions heurístiques esmentades queden especialment patents en dos fets: d'una banda, ens hem vist obligats a constrenyir-nos - per la manca de dades o la incertesa de les mateixes per la resta de quarters- a centrar-nos en l'estudi concret dels quarters de la Plaça i Montseré en l'any d'abundor documental de 1366 i, d'altra, del nombre complet i màxim de cinquanta-sis individus amb responsabilitats polítiques per cada quarter, $n$ 'hem pogut identificar amb els criteris esmentats una trentena per cadascun dels dos quarters estudiats. En raó d'aquests imposats límits heurístics, cal entendre el caràcter molt restringit de les afirmacions que vessarem en el present capítol que, com hem exposat molt més amunt al parlar del mètode, esdevé gairebé el que podriem anomenar un assaig d'experiment metodologic. 
sempre havien pertanyut al cos d'electors, amb la qual cosa havien participat en la seva autoelecció.

Sòcio-professionalment, la major part de paers (un 65\%) eren mercaders i notaris $i$, a partir del 1368 , aproximadament, també juristes. A més d'aquests tres grups hi havia un col lectiu considerable d'individus no identificats segons coordenades sòcio-professionals. Sabem que, en general, no eren rendistes, però tampoc no pot garantir-se que fossin pagesos benestants, tot i que és la suposició més probable. Entre 1357 i 1388 la presència de mercaders i notaris va ser particularment intensa, però al final del segle XIV la participació de mercaders va declinar en benefici d'artesans $i$ juristes. Una composició semblant s'observa entre els consellers, per bé que notaris i juristes no estaven tan representats. Els oficis continuaven amb una incidència circumstancial, però en canvi s'adverteix la presència, minsa això no obstant, de representats del món feudal. Entre els electors augmenta considerablement el paper dels oficis, especialment al quarter de Framenors, mentre que a la Plaça tenen una importància totalment marginal.

Quan s'intenta d'esbrinar el caràcter i l'actitud econòmica dels mercaders i dels notaris a través de l'arrendament d'imposicions i gaudi de rendes, hom s'adona que hi ha una immensa majoria de paers i consellers mercaders que inverteixen en les Imposicions municipals, encara que només una tercera part d'aquests efectua inversions notables a través, sobretot, de les Imposicions de la carn, del vi i de la farina. Aquests mateixos individus són, en general, aquells qui a més a més es beneficien de rendes de censals i violaris. Els mercaders en el govern municipal que només siguin rendistes són molt pocs en nombre, i representen una proporció sense importància. En canvi, predominava el tipus de mercader que tant invertia en Imposicions com també rebia rendes. Aquesta era l'actitud més generalitzada entre el grup de mercaders aparentment més potent abans que acabés el segle (la darrera comptabilització de rendes és del 1383). No s'ha d'excloure la possibilitat que aquesta tendència canviés de sentit uns quants anys més tard. El perfil de l'actitud econòmica dels notaris que van accedir als càrrecs de paer i de conseller, des de l'anàlisi de les Imposicions i les rendes, és el d'uns personatges un sector dels quals decidí d'invertir la seva riquesa en l'arrendament d'Imposicions o l'adquisició de censals i violaris. Aquesta actitud d'inversió en una modalitat o altra és pròpia d'un $59^{\prime} 4 \%$ dels notaris paers-consellers. L'altre 40'6\% de notaris no ens consta que invertís la seva riquesa en cap d'aquestes dues modalitats.

Ultra l'anàlisi sòcio-professional dels càrrecs de govern, l'estudi des d'una òptica sòcio-econòmica ha revelat aspectes interessants. En termes generals, durant el segle XIV s'observa amb claredat que els individus amb taxacions més altes, que són una clara minoria entre la població, en canvi esdevenen una clara majoria entre el cos de paers. Es pot assenyalar que el govern municipal es troba 
substancialment dominat per aquests individus més rics. Però aquesta hegemonia política dels més alts manifestants, tot i ser aclaparadora, no arriba a ser absoluta. Individus classificables com a "mitjans manifestants" també intervenen en la màxima magistratura local amb un percentatge que no és gens insignificant. Entre els consellers la situació és una mica més equilibrada, ja que aproximadament la meitat dels individus que ho van ser són dels mitjans manifestants. Però aquest fenomen no el podem atribuir a cap acció de caràcter polític. Senzillament cal interpretar que els individus amb els manifests més elevats eren massa pocs -en termes absoluts- per a poder copar els oficis de conseller a més a més del de paer. Per un problema purament "tècnic» la majoria de consellers no són del col lectiu més poderós pel que a riquesa taxada es refereix. El fet que cada any s'haguessin de triar vint consellers, a més de quatre paers, gairebé obligava a permetre l'accés al govern municipal a un ventall social aparentment més ampli. Més endavant ens referirem a si el $\mathrm{col} \cdot$ lectiu integrat pels màxims manifestants era subocupat políticament o si, al contrari, la seva participació al govern municipal era activa. Entre els electors es manté l'alta participació del grup de mitjans manifestants i creix molt el grup, fins a més de la meitat del col-lectiu d'electors, dels individus amb patrimonis més baixos.

També, en termes generals, la participació política dels grups sòcioeconòmics respon a un esquema segons el qual el grup d'individus amb taxacions més baixes presenta una àmplia participació política a mesura que disminueix la importància de l'òrgan polític en el qual participa. De la mateixa manera que aquest grup gairebé no participa en els òrgans de major transcendència política, els estrats sòcio-econòmics més alts presenten el comportament contrari. A una major importància de l'òrgan polític correspon una presència majoritària de membres d'aquest col-lectiu $i$, viceversa, llur presència és insignificant en els òrgans menys importants. L'espai entre els majors manifestants i els més modestos, que correspon a un estrat mitjà, presenta un comportament de transició, té poc pes entre els paers $i$, en canvi, bastanta representativitat entre consellers i electors.

En un context de manca de sèries completes d'informació sobre els temes que tractem, l'any 1366 és el que ens ofereix més referències a càrrecs polítics identificats sòcio-econòmicament a partir dels manifests, ja que coneixem els

"Per poder comparar la trascendència sòcio-econòmica dels paers, consellers i electors de quarters amb diferents mitjanes i umbrals de riquesa, hem tipificat el valor de la riquesa d'aquells individus a fi de poder operar més facilment i fer-ne les comparacions oportunes prescindint de valors absoluts de riquesa. Amb això estalviem de trobar-nos amb casos en que, per exemple, l'individu més ric d'un quarter no passaria de tenir una fortuna mitjana en un altre. Vid. Figura 13 i Figura 14. 
noms $\mathrm{i}$ les fortunes dels paers i de la majoria de consellers i d'electors dels quarters de la Plaça i de Montserè ". En ambdós casos els respectius paers es troben lluny d'ésser els dos màxims contribuents del quarter. Pere Serra $\mathrm{i}$ Ramon Martí, paers dels quarters de la Plaça i Montserè respectivament, estan per sobre de la mitjana tipificada de la riquesa, però formen part del que podríem anomenar una franja mitjana de riquesa avaluada. En canvi, els quatre consellers degudament identificats de cada quarter presenten situacions diferents. Tant a la Plaça com a Montserè hi ha des de consellers amb fortunes bastant pròximes als màxims contribuents fins a consellers amb una tipificació de la seva riquesa per sota de zero. La distribució dels consellers entre l'aspectre econòmic presenta una regularitat considerable. Van ser consellers els electors més rics i també ho van ser els gairebé més pobres. S'ha de tenir en compte, en tot això, que el cos d'electors de cada quarter, com ja ho hem exposat, proposava tres $\mathrm{i}$ deu individus dels quals, per atzar, un i cinc resultarien escollits paer i consellers, respectivament. Aquest element atzar juntament amb la reglamentació antirrepetició de càrrecs pot ajudar a comprendre que els càrrecs de govern no estessin copats sempre pels més rics. Aquesta varietat entre els consellers encara és més palesa entre els electors. Sòcio-professionalment les dades del 1.366 revelen una intensa presència de notaris $\mathrm{i}$ juristes dins del Consell. Entre els electors més rics de cada quarter hi ha professionals del Dret: a la Plaça és el jurista Pere Bonanat, elector, i a Montserè els notaris Antoni Toldrà i Pere Dan, conseller i elector respectivament. Altrament, també va ser conseller de la Plaça el notari Pere Canet, per bé que pertanyés a una posició econòmica força modesta. Aquestes dades indiquen que van ser electors alguns notaris «rics" i també notaris "pobres», però només un dels primers va ser conseller aquell any. El paer de la Plaça va ser mercader, però se situava en una franja mitjana de riquesa.

El comportament general per a la segona meitat de segle XIV que hem descrit pot explicar-se també a partir de raonaments tècnics, però en aquesta ocasió s'hi amaga un element polític important, ja que s'observen discordàncies entre la força potencial o demogràfica dels sectors modestos i llur representació en l'òrgan de govern més elevat. L'àmplia representació dels modestos i mitjans manifestants entre els consellers i sobretot entre els electors, no garantia que aquests grups predominessin en un govern municipal dirigit pels paers. Més aviat hauriem de pensar que en els casos de paers del col-lectiu de màxims contribuents, aquests havien arribat al càrrec polític gràcies al suport d'individus d'un altre nivell impositiu. En les relacions de poder que es desprenen de l'elecció del Consell sembla predominar tant o més la fidelitat o el vincle personal que no pas la cohesió i la solidaritat del grup, de manera que individus amb taxacions de béns molt baixes havien col-laborat a elegir com a paers individus amb les taxacions més altes. Els primers no accedien de manera continuada a l'òrgan executiu del Consell, però ajudaven que ho fessin els 
segons. Aquells paers amb taxacions elevades no sols accedien al poder municipal, sinó que a més hi duien una vida política activa i continuada.

La reiteració en els càrrecs del govern municipal a Cervera era regulada per dos privilegis reials de 1311 i 1316 , per mitjà dels quals es fixava el període necessari per a la reelecció. Cap tret o característica especial no defineix els paers més constants en el govern municipal. Manifesten una activitat professional, un origen sòcio-professional i una actitud rendista semblant a la de la resta del col lectiu de paers. No pot dir-se, per tant, que els qui més repetiren de paer van ser els individus amb taxacions més altes, ni que fossin únicament notaris o mercaders, ni que fossin els rendistes més coneguts. No coneixem, doncs, els motius que expliquen per què van ser precisament aquests els paers més reiteratius ni si hi ha cap criteri que ho expliqui. Els vincles personals, el prestigi social o personal, l'eficàcia o el mateix esperit polític de cada individu són tots plegats uns factors que no podem explicar a partir de la documentació que hem utilitzat. Entre els consellers s'observa un comportament semblant, per bé que no hi ha tanta reiteració com entre els paers. Prenent com a referència el conjunt de paers i consellers plegats, que eren els estrictes integrants del Consell, s'observa que d'una part es mantenia el termini de reelecció dels quatre anys fixat al començament de segle, però s'utilitzava una interpretació particular segons la qual el termini de reelecció es referia a la repetició d'un mateix tipus de càrrec (de paer a paer o de conseller a conseller). Aquesta interpretació restrictiva i particular permetia, per tant, accedir a la Paeria en terminis inferiors als quatre anys establerts. Però, en fer-ho a mb càrrecs diferents, s'entenia que no es vulnerava cap disposició establerta. Els casos d'individus que no van esperar quatre anys per a ocupar alguns càrrecs van ser nombrosos $i$ esdevenen una pràctica generalitzada.

Els paers i consellers més proclius a la reiteració de càrrecs van ser mercaders i notaris que eren dins del grup de les taxacions més elevades. Si bé s'ha d'acceptar que va existir la reiteració de càrrecs, cal matisar que entre els paers els nivells de reiteració van ser "moderats», sense arribar a un control absolut dels càrrecs ni tampoc a una distribució àmplia. Aquest fenomen devia ser resultat de la disposició del 1316 que regulava aquests aspectes institucionals. Això no obstant, aquests individus paers que no abusaren de la reiteració del càrrec de paer, sí que van ocupar molt sovint càrrecs de conseller dins del període de quatre anys. Però els personatges que més van repetir entre els consellers no coincideixen amb els seus homòlegs entre els paers, amb la qual cosa sembla posar-se d'evidència la diferent consideració política d'ambdós òrgans de govern.

Mentre que la reiteració ateny la periodització en l'ocupació dels càrrecs, l'acumulació d'aquests fa referència al nombre absolut de càrrecs i responsabilitats de govern i gestió que van mantenir els membres del Consell. Segons 
l'adscripció sòcio-professional, els individus més acumuladors van ser mercaders i notaris, mentre que, segons categories sòcio-econòmiques, el major nivell d'acumulació estava en mans dels individus més potents $i$, contràriament, el nivell més baix d'acumulació de càrrecs pertanyia, tret d'algun cas aillat, a individus amb taxacions baixes.

La concentració de càrrecs i responsabilitats tenint en compte els òrgans de govern és interessant per a comprendre l'evolució i la tendència de la dinàmica de poder interna del Consell. Sembla poder-se deduir que el règim municipal ha sofert un procés de tancament progressiu d'ençà que fou reorganitzat el 1331. Aquest tancament s'ha operat, a nivell institucional, entorn dels paers, que s'han anat configurant com un veritable òrgan executiu i com a pedra de toc del poder de la institució. Si la normativa del 1316 continuava vigent - i sembla que era així- i limitava la repetició en l'accés al poder, els col ·ectius més influents necessitaven una altra via per a canalitzar la seva influència. Repartir càrrecs entre els prohoms -que en certs casos eren paers que en virtut del límit dels quatre anys no podien ser-ho aleshores- hauria estat una solució per a continuar manant sense ser al Consell formalment. L'accés al càrrec de conseller era una altra solució, ja que la norma del 1316 s'havia interpretat generosament; però, a la realitat, ser conseller no oferia cap avantatge sobre els prohoms, tret del grau honorífic. Contràriament a aquestes solucions possibles, el pes dels prohoms es redueix en general, i el dels consellers continua baix com sempre. No obstant això, continuem trobant prohoms, menys que en èpoques anteriors, que consten entre els màxims acumuladors de càrrecs. En certa mesura, és possible que coincideixin dues tendències oposades. La concentració en mans dels paers perjudica els prohoms, però no tots indiscriminadament, ja que alguns continuen rebent una part considerable de responsabilitats i, per tant, de participació en el govern minicipal. Però aquests prohoms que persisteixen no ho fan dins aquella tendència inicial a repartir molt els càrrecs sinó, al contrari, com a participants d'un govern cada vegada més tancat. Hem vist abans que eren mercaders i notaris que no solament acumulaven càrrecs, sinó que accedien reiterativament al govern municipal i que, en llur majoria, eren individus considerablement potents econòmicament. 


\title{
IV. LA PRODUCCIÓ SOCIAL DE L'ESPAI URBÀ MEDIEVAL: PRESTIGI SOCIAL I SEGREGACIÓ SÒCIO-ESPACIAL
}

\begin{abstract}
"La segona ma dels habitadors de la ciutat s'apella ma mitjana, e aquests no s'apellen honrats ciutadans, mas son apellats ciutadans així que no hi ajusta hom altre vocable d'honor, així com fa als generesos. E sots aquesta ma se comprenen comunament juristes, notaris, meriaders, e drapers poderosos, e tots aquells qui sens generositat notable han gran riquees en la ciutats
\end{abstract}

Francesc Eiximenis"'

Per tal d'entrar a veure la repartició espacial de la riquesa social i adonar-nos com la morfologia urbana encabeix de manera diferenciada riquesa i professions (tot reflectint el fenomen social que coneixcm com a segregació social), ens és imprescindible conèixer -encara que només sigui a nivell superficial- el caràcter específic i el significat de les divisions en districtes o quarters en relació a la visió dels contemporanis i com aquests quarters -en què es va dividir idealment la vila als efectes administratius- embolcallen un espai físic urbà i social bàsic format pels carrers.

Si bé resulta evident que la centralitat urbanística és primer que res un fenomen més aviat de posició geogràfica, cal no oblidar que l'espai urbà és bàsicament $\mathrm{i}$ essencialment un producte social que es va formant en base a les condicions que imposa el mode de producció predominant en una formació social concreta ${ }^{\text {* }}$. A redós d'aquesta teoria s'han anat desenvolupant força aportacions empíriques d'estudis de morfologia sòcio-urbana, però la gran majoria - per no dir la totalitat- d'aquestes aportacions s'han fet entorn de societats on el mode de producció predominant és el capitalista ${ }^{" 1} i$, per tant, el

\% Vid. Figura 11 (Plànols: Segregació sòcio-espacial de Cervera per quarters i segrega(io espacial per riquesa moble, immoble i total; i quadres de migracions entre quarters i carrers).

" Eiximenis, Dotzè del Crestica, p. 115. La cursiva és nostra.

y Sobre aquesta mancra d'entendre la morfologia urbana, encara que centrada bàsicament en els modes de producció capitalista i socialista com a productors d'espai urbà vid. David Harvey, Urbanismo y desigualdad social, Madrid, 1979)', pp. 262-273, esp. p. 272. Juan Eugenio SÁNChez, Poder y espacio, "Geo-crítica. Cuadernos críticos de Geografía Humana», 23 (1979), pp. 19-24. Fn un context totalment català, resulta especialinent interessant per aquest tema -i per ser un treball empíric- la tasca desenvolupada per dos arquitectes sobre Barcelona: Albert García I Espuchi: i Manuel Guárdia I Bassols, Espai i Societat a la Barcelona pre-industrial, Barcelona, 1986.

'x Per un plantejament de la producció d'espai urbà en el capitalisme espanyol actual, vid. Horació CAPF́. SÁEz., Capitalismo y morfologia urbana en España, Barcelona, 1977: i també Carme MASSANA, Indústria, ciutat i propietat. Política econòmica i propietat urbana d l'àrea de Barcelona (1901-19.39). Barcelona, 1985. 
nostre interès per la morfologia sòcio-urbana en el feudalisme declinant resulta escapçat teòricament: com es produeix l'articulació ciutat-feudalisme a nivell espacial i sòcio-espacial dins la ciutat?

La forma construïda de la ciutat medieval reflecteix l'ordre social de la seva època, on tres motius centrals (leit-motivs) en dominen l'espai: el castell, l'església i el mercat. La dialèctica d'aquests tres elements anirà configurant l'espai; quan l'activitat comercial es desenvolupa i acapara i domina la ciutat, les grans aglomeracions urbanes desenvolupen una estructura que tant presenta una considerable segregació residencial com una segregació d'activitats. Aquests models no van ésser tant el resultat d'una segregació funcional de les forces de treball, sinó més aviat representacions simbòliques i territorials de la posició relativa aconseguida dins l'escala de prestigi de l'ordre medieval ${ }^{100}$. Addhuc els peculiars barris artesans de les grans ciutats reflectien tant les consideracions de prestigi com les necessitats econòmiques imposades per una divisió del treball cada cop més complexa.

Algunes activitats, particularment aquelles relacionades amb el moviment de materials pesats, van ésser localitzades d'acord amb un premeditat pla racional als afores del casc urbà. Tanmateix, la riquesa era un índex de prestigi i les localitzacions de prestigi eren, en la seva gran majoria, properes al centre simbòlic de la ciutat redistributiva medieval. Els valors del sòl reflectien la competència per les localitzacions de prestigi. Malgrat això, era l'ús el que determinava el valor de canvi en el mercat del sòl urbà en una societat jeràrquica com la medieval, en contrast amb períodes posteriors en què el benefici sobre la inversió va arribar a determinar per complet l'ús. Evidentment, el mercat del sòl urbà estava molt influît per la manipulació i la posició dels rendistes era tan avantatjosa com prestigiosa (per no parlar del seu caràcter lucratiu i estable).

Tota l'estructura espacial de la ciutat medieval reflecteix els criteris típics d'una societat jeràrquica. La forma construïda de la ciutat medieval reflecteix d'aquesta manera la necessitat que tenien aquells qui ocupaven posicions de poder $i$ de prestigi en la societat d'utilitzar l'espai $i$ la forma arquitectònica com a representacions simbòliques d'aquest poder o com a representacions simbòliques d'aquelles imatges còsmiques a les quals la societat jeràrquica continuava recorrent per al seu manteniment moral. Els trets distintius de l'estructura urbana anaven destinats a reflectir els valors característics de l'època, valors que eren expressions ideològiques del mode de producció dominant, del seu mode característic d'integració econòmica i social $i$, de vegades, del seu caràcter dissolvent, que preveia l'aparició d'un mode de producció totalment nou.

(111) SJOBERG, Le cità dei padri, pp. 85-108. 
IV.1. La segregació sòcio-espacial: la configuració del quarter de la Plaça com a centre-vila ${ }^{101}$

A primera vista i de manera general, l'evolució històrica dels quarters cerverins ens presenta dos trets característics:

1) el quarter central de la Plaça és el més especialitzat respecte del terciari, en contrast amb els restants que mantenen una preponderància (desequilibrada, però) dels sectors primari i secundari;

2) el sector secundari, però, presenta un augment general (en segon terme) arreu de tots els quarters.

Una més acurada observació de cadascun dels quarters per separat ens ofereix una imatge més precisa de les tendències generals abans apuntades.

El primer tret que salta a la vista és l'existència d'uns quarters que podríem anomenar estables (Cap Corral i Framenors), això sí, per motius diferents: mentre que Cap Corral presenta una estabilitat propera a l'estatisme, Framenors es troba de tal manera entrampat pel fet d'ésser una observació única que no ens és permès d'emetre gaires judicis. En canvi, els altres quarters (Montserè i la Plaça) són dinàmics: mentre que Montserè presenta una progressiva especialització secundària, la Plaça té tendència a l'especialització terciària.

El quarter de Framenors (1375), evidentment com a resultat de la manca d'altres dades, ens resulta dificultós en el seu estudi, però -almenys- semblen clars alguns trets: en primer lloc, a nivell dels manifestants, la seva composició és aclaparadorament primària $(72,36 \%) \mathrm{i}$, en canvi, respecte de la riquesa total, tot i essent considerable el primari $(53,15 \%)$, s'ha diversificat. Un potent sector secundari a nivell poblacional $(18,59 \%)$ controla molt poca riquesa $(14,34 \%)$, riquesa i població secundàries majoritàriament dedicades a les manufactures de la pell $\mathrm{i}$ del tèxtil, representant ambdues manufactures juntes gairebé la totalitat $(90,49 \%)$ de la indústria del quarter. Un considerablement petit sector terciari $(9,04 \%)$ controla una riquesa important $(32,51$ $\%)$, però en aquest darrer, essent el pes de la riquesa immoble molt fort $(26,3)$ $\%)$, l'únic que ens revela és que gairebé tot l'immoble del terciari és acaparat pels comerciants $(20,60 \%)$ que són només el $5,52 \%$ de la població total del quarter.

El que sí que, en canvi, presenta els caràcters del que podríem anomenar quarter estable, per no dir fins i tot estàtic, és Cap Corral (1340-1369). Mentre

111'Vid. totes les Figures de la sèrie 11: Segregació espacial, segregació sòcio-espacial i les Figures 11.1 i 11.2: Migracions professionals entre quarters i entre carrers respectivament. Vid. també la Figura 12.2: Estructura professional per quarters. 
que el caràcter predominant del sector primari i, en especial, de la seva riquesa immoble són com unes constants en el quarter, a nivell poblacional s'observa una petita redistribució de la pagesia entre els sectors secundari i terciari. Respecte de la riquesa total, el canvi és gairebé inapreciable (l'estabilitat de l'immoble encobreix la minúscula variació del moble), però, dins de l'estatisme regnant, ressalta com a únic canvi apreciable el bescanvi dels detentors de la riquesa immobiliària del terciari, que d'estar en mans dels comerciants l'any 1340 passa a mans de les professions liberals l'any 1369.

De tota manera, els quarters més interessants són els de Montserè i la Plaça pel fet d'ésser els més dinàmics; Montserè sembla configurar-se com un quarter manufacturer i, en canvi, la Plaça esdevé un centre de serveis i d'altres activitats terciàries.

La tendència vers l'especialització manufacturera del quarter de Montserè (1366-1378) és palesa sobretot en el fet que Montserè és l'únic quarter on la població abandona el sector terciari $(19,07 \% \Rightarrow 14,67 \%)$ en benefici del secundari $(9,86 \% \Rightarrow 14,22 \%)$ davant la proverbial estabilitat del primari $(71,05 \% \Rightarrow 71,10 \%)$; un procés, aquest, que detectarem, gairebé en els mateixos termes, a nivell de riquesa: allò que el terciari perd $(45,12 \% \Rightarrow 30,99$ $\%)$ ho adquireixen de manera repartida primari $(50,59 \% \Rightarrow 58,75 \%)$ i secundari $(4,29 \% \Rightarrow 10,26 \%)$. L'increment, però, i val la pena notar-ho, de primari i secundari no es produeix en la riquesa moble -com hom hauria de suposar-ho si es tractés d'una inversió en la manufactura-, sinó que es decanta totalment vers la riquesa immobiliària, tant en el sector primari $(40,07$ $\% \Rightarrow 53,53 \%)$ com en el secundari $(3,51 \% \Rightarrow 9,07 \%)$ : la qual cosa l'únic que sembla indicar-nos és una tendència general vers el rendisme dels sectors productius. Si bé la davallada del terciari afecta fortament la riquesa immoble $(36,48 \% \Rightarrow 24,40 \%)$, el canvi es produeix en com es distribueix aquesta davallada socialment: mentre que els comerciants conserven i mantenen la seva riquesa immoble $(15,71 \% \Rightarrow 15,96 \%)$, són les professions liberals les que perden de manera acusada la seva riquesa immobiliària $(20 \% \Rightarrow 7,40 \%)$. L.'especialització manufacturera del quarter de Montserè es centra sobretot en les indústries pelletera i tèxtil, ja que ambdues controlen l'any 1366 quasi la meitat $(47 \%)$ de la riquesa del sector per passar l'any 1378 a controlar-ne gaircbé les tres quartes parts $(69,95 \%)$; val la pena fer notar que la resta del sector és format pel subsector de la construcció.

El quarter de la Plaça (1352-1366-1382) presenta unes característiques de clara especialització, per bé que aquesta és força dicotomitzada entre els sectors secundari i terciari, essent, però, aquest darrer el de més pes específic en el quarter. El primer tret que salta a la vista és el descens continuat del sector primari, tant a nivell poblacional $(65,92 \% \Rightarrow 59,57 \% \Rightarrow 50 \%)$ com de riquesa total $(49,88 \% \Rightarrow 35,55 \% \Rightarrow 27,32 \%)$. Cal constatar, però, que la forta davallada de la riquesa no sembla correspondre's en el seu ritme amb el descens 
poblacional: aquest fet sembla voler-nos indicar que som davant més aviat d'una proletarització de la pagesia acompanyada d'una pauperització, i la pèrdua considerable de riquesa immoble sembla confirmar-ho $(41,02$ $\% \Rightarrow 29,53 \% \Rightarrow 24,44 \%)$. La promoció del sector secundari es produeix, tant a nivell poblacional $(13,71 \% \Rightarrow 13,82 \% \Rightarrow 18,75 \%)$ com de riquesa total $(4,13 \% \Rightarrow 9,86 \% \Rightarrow 13,75 \%)$, sobretot arrossegat per la riquesa immoble $(2,98 \% \Rightarrow 6,06 \% \Rightarrow 10,10 \%)$, tal i com també ho havíem pogut apreciar al quarter de Montserè. Convé palesar que, mentre el canvi a nivell de riquesa és continu i ascendent, a nivell poblacional només hi haurà l'estrebada forta ascendent en el període 1366-1 382: això sembla més aviat indicar-nos que l'especialització creixent del sector terciari (que veurem més endavant) duu com a valor afegit l'atracció de la manufactura més especialitzada, exclusiva i luxosa com és la de la guerra. La incorporació d'artesans dedicats a la fabricació d'armes (ballesters, manyans i espasers) l'any 1382 és força significativa, ja que llur indústria (amb pocs membres, tot val a dir-ho: tots plegats són quatre persones) acapara una riquesa que representa el 12,68\% del sector, tot trencant l'equilibri tradicional entre pellers i teixidors que fins aleshores controlaven la meitat, si fa no fa, de la riquesa sectorial $(67,18 \% \Rightarrow 51,30 \% \Rightarrow 59,95 \%)$; un equilibri que a les acaballes del segle sembla decantar-se vers el sector pelleter (la sabateria, sobretot). Cal indicar, d'altra banda, que artesans d'armes i pelleters són proveïdors directes de les classes altes, i sobretot els primers, dels senyors feudals de la rodalia; però que, per això mateix, es caracteritzen perquè poden comercialitzar directament els seus productes tot desempallegant-se dels intermediaris comercials (els comerciants). Respecte del sector terciari és convenient adonar-se de la diferència de ritmes evolutius d'ascens entre població $(20,35 \% \Rightarrow 26,59 \% \Rightarrow 31,25 \%)$ i riquesa total $(45,99 \% \Rightarrow 54,59$ $\% \Rightarrow 58,93 \%$ ), la qual cosa sembla voler indicar-nos que el canvi prové més aviat de la vinguda d'elements foranis (immigració des d'altres quarters per atracció del centre-vila d'alt nivell de vida, poder $i$, sobretot, prestigi social) que no pas d'un creixement econòmic intern; hipòtesi que sembla confirmar-se si tenim en compte dos trets addicionals: d'una banda, la riquesa immoble es manté prou estable $(39,30 \% \Rightarrow 40,52 \% \Rightarrow 48,39 \%$ ) en general $i$, d'una altra, mentre que els comerciants mantenen la seva quota de participació immobiliària $(23,49 \% \Rightarrow 16,41 \% \Rightarrow 2(), 7() \%)$, són les professions liberals les que experimenten l'augment constant a l'alça $(14,28$ $\% \Rightarrow 22,12 \% \Rightarrow 26,96 \%)$. Mentre que el nivell humà de comerciants es manté gairebé fix durant tot el període, són les professions liberals i, en especial, els juristes (notaris i savis en dret) els qui van arrelant-se com a habitants del quarter $i$, com que és prou sabut que la formació professional dels homes de lleis no és cosa de dies ni de pocs anys, només podem explicar el fenomen acollint-nos al factor migratori. 


\section{IV.2. El prestigi social del centre (la Plaça): des del comerç a les professions liberals}

Si bé fins ara ens hem anat ocupant de les unitats majors de la morfologia urbana (els quarters) i des d'una visió entre els quarters, convé ara que davallem fins a arribar a les unitats menors (els carrers) $i$ ens endinsem en una visió de dins els quarters.

Però, bé que la nostra pretensió consistia a poder apreciar la realitat morfològica de la vila a través d'aquests indicadors, cal advertir d'entrada que llur fiabilitat és tan aproximada com podia ser-ho la dels quarters i que sovint hem hagut de suplir les mancances de la font en referir-nos als carrers mitjançant la hipòtesi de considerar que els mateixos i/o semblants habitants haurien de perdurar alguns anys al llarg del període estudiat; així, els casos on ha estat necessari recórrer a les interpolacions són: els carrers CV (46), BSC (36) i DPO (14). Cal afegir que, respecte del quarter de Framenors -com calia esperar essent una observació única en el temps- es plantejava una situació especial: per tal de donar-hi una solució i per la ubicació dels carrers, hem hagut de recórrer a aproximacions per referències actuals -practicar la història oral amb una distància de més de sis-cents anys resulta una mica massa agosarat, però, de vegades, els ancoratges històrics, converteixen alguns llocs en veritables illes del temps $i$, allà, el record pot perdurar-hi segles- $i$ així hem situat els carrers $\mathrm{AB}$ (21) i $\mathrm{P}$ (23) però, per més esforços que hem fet, el carrer $\mathrm{D}(24)$ se'ns ha resistit. Altrament i per raons ben diferents, mantenim en el silenci el carrer $\mathrm{CJ}$ (50) o call jueu; la raó del silenci resideix en el caràcter de la nostra font ja que, essent una font de caire fiscal municipal, no contempla la població del "ghetto» jueu perquè aquests habitants depenien fiscalment de manera directa de la corona catalana i es mantenien al marge de la fiscalitat municipal; però, tot $\mathrm{i}$ això, llur presència no ens és gens desconeguda i llur caràcter ha estat estudiat a la nostra època per Prim Bertran i Roigé ${ }^{102}$.

La nostra aproximació és, doncs, hipotecada des de bon començament, però l'interès de les dades ens permet arriscar-nos al seu estudi.

La simple observació superficial dels mapes de les mitjanes de riquesa $\mathrm{i}$ dels sectors professionals ens revela una característica prou important: el carrer de la Plaça (45) va configurant-se, al llarg dels anys, com el centre neuràlgic de la vila (el centre-vila).

Ens queda, doncs, prou delimitat el fet que el carrer de la Plaça (45)

102 Prim Bertran ROIGE, Els jueus en els Llibres de Batlle $i$ Cort de Cervera ( 1.354-1.357), "llerda (Miscel lània Homenatge a Josep Alfons Tarragó i Pleyan)», XLIV (Lleida, 1983) pp. 189)-205. 
funciona com a centre-vila en acumular grans dosis de representativitat simbòlica pel fet de concentrar els tres elements fonamentals: la Paeria com a centre de poder temporal, l'Església Major com a centre de poder espiritual i la Plaça Major, on es celebrava el mercat, com a centre econòmic.

Resulta, altrament, prou interessant constatar l'evolució temporal d'aquesta consagració de centralitat.

A mitjan segle (1352), el carrer HSJ (44) figura com el que concentra més riquesa per càpita $\mathrm{i}$ hi predomina com a activitat fonamental el comerç; en canvi, el 1366 ens trobem amb una mutació espacial considerable: els comerciants i professionals liberals que habitaven el carrer HSJ (44) migren vers el centre geogràfic $\mathrm{P}(45)$, mentre que la seva arribada desplaça la pagesia que hi habitava vers el carrer CV (46); pagesia i professions liberals són prou benestants com per a poder crear un segon centre-ciutat paral·lel que, el 1382, perdrà el potencial econòmic perquè l'arribada d'aquella pagesia provocarà una pauperització $\mathrm{i}$ conseqüentment la pèrdua de la centralitat; el 1382, en canvi, per al centre (45) significarà una diversificació i un enlairament fort del potencial econòmic, ja que no hi ha només comerciants, sinó que les professions liberals que havien arribat el 1.366 han prosperat i ha aparegut una nova força, l'artesanat, més o menys especialitzat en produccions de luxe (recordeu els artesans dedicats a la producciómanufactura d'estris de guerra). Sobre la importància de les professions liberals jurídiques (notaris, savis, escrivans, etc.) a les viles medievals meridionals, no cal insistir-hi gaire i llur funció social ja ha estat posada prou de relleu per André Gouron ${ }^{103}$.

Sense intenció de fer-nos pesats, cal adonar-nos de les diferències en la distribució espacial de les riqueses immoble i moble.

En el primer període (1340-1352), la diferenciació espacial s'estableix entorn de la riquesa immoble perquè a nivell de la riquesa moble no hi ha diferències entre el carrer $44 \mathrm{i}$ els rics que l'envolten: un cert rendisme i la crisi poden explicar el fenomen.

En el segon període (1366-1366-1369), mentre que la pauta continua marcant-la la riquesa immoble, cal adonar-nos que el carrer 33 té un fort component mobiliari, segurament explicable per la presència allà de comerciants i professionals liberals que atressoraven béns de luxe domèstic.

En el tercer període (1375-1378-1382), la nota discordant la presenta el carrer 21 , que té un fort moble explicable per un terciari de poca base immobiliària.

1'" André Gouron, Le rôle social des juristes dans les villes meridionales au moyen âge, in Villes de l'Europe mediterranéene et de l'Europe occidentale du moyen âge au XIXe siècle. Nice, 1969, pp. 55-67. 
V. CONCLUSIÓ: DIFERENCIACIÓ SOCIAL I DISTRIBUCIÓ SOCIAL DE L'ESPAI A LA CERVERA BAIXMEDIEVAL. PATRICIAT URBÀ I SEGREGACIÓ SÒCIO-ESPACIAL

«Die Stadtluft macht frei» (L'aire de la ciutat fa lliure)

Aquest vell i medieval proverbi alemany continua colpint sovint els historiadors: la veritat de sentit comú que amaga, com tots els refranys populars, roman enganyosa als ulls dels homes postil-lustrats del segle XX. Només és possible descabdellar-ne totalment el sentit recorrent al constant nus gordià de la disciplina històrica: practicar al més profundament $\mathrm{i}$ àmpliament possible la recerca empírica arreu del temps i de l'espai; però, tanmateix, els estrets límits heurístics de la història medieval ens han forçat -en el nostre casa circumscriure la nostra empíria a allò perceptible des del microscopi local cerverí.

La metàfora, gairebé feuerbachiana, del proverbi ens recorda clarament $\mathrm{i}$ directa el problema històric on ens haviem endinsat: com cal considerar $\mathrm{i}$ entendre la ciutat en el feudalisme? $\mathrm{O}$ bé com a cèl · lula antagònica i cancerígena ${ }^{101}$ o bé com a cos social plenament integrat i conformista amb el sistema feudal "'s'. La nostra opció teòrica ens duia a estudiar l'estructura social de classes de la ciutat $i$, a partir del model dibuixat per Nell, això volia dir centrar-nos en l'anàlisi de l'evolució històrica de l'èlit social que dominava i governava la ciutat. Del mateix model i de les dades històriques de l'evolució sòcio-econòmica europea baixmedieval, semblava delinear-se un esquema segons el qual, en aquest període, s'havia produit la transició, des d'una èlit única i homogènia formada pels senyors de la guerra, vers una èlit diversificada $i$ heterogènia composta per un conglomerat de comerciants i artesans. Aquesta èlit, fonamentada en el poder econòmic havia entrat, durant la primera crisi general del feudalisme, en un procés de descomposició interna en eixamplar-se les divisions interiors $\mathrm{i}$, com a resultat, els comerciants havien anat perdent la seva posició econòmica privilegiada d'intermediaris per anar-se integrant dins d'un bloc de poder conjuntament amb els terratinents feudals (una munió d'interessos, sobretot de caràcter rendista immobiliari, els mancomunava) i, en

${ }^{10.1}$ Michacl M. POSTAN, El comercio, p. 223; "[las ciudades medievales cran] como) islas no feudales en un mar feudal".

101 Rodney HiLton, Las ciudades en la sociedad feudal inglesa, p. 112 "(..) las ciudades son parte de la formación social feudal y estan implicadas en sus contradicciones -sin ser el principio de contradicción-." 
canvi, els artesans -en general- havien anat guanyant llocs en l'escala social pel fet d'haver pogut prescindir, a causa de la comercialització directa dels seus productes manufacturats, dels antics intermediaris comercials. Des d'aquest model i un cop examinades les dades proporcionades pel Manifest cerverí i explicitats els nostres resultats parcials de manera continuada i al llarg de tot el treball, ara només caldrà recapitular els nostres resultats globals per a poder procedir a la seva verificació, rebuig o modificació.

Cervera era, a mitjan de segle XIV, una vila de jurisdicció reial enmig d'una mar de jurisdiccions senyorials, la vuitena ciutat en importància de Catalunya $i$, com a centre urbà, exercia de capital d'una àmplia comarca rural on no hi havia cap altra ciutat comparable; aquesta capitalitat es fonamentava, d'una banda, en la seva grandària i ubicació i, d'una altra, en el fet d'aglutinar en el seu interior una gran densitat d'activitats manufactureres i de serveis de la rodalia i actuava, mercès a l'existència d'un mercat fix i d'una certa producció artesanal, com el lloc on la pagesia de la rodalia procurava monetaritzar el seu excedent per adquirir aquests productes manufacturats i/o pagar les exaccions senyorials. Des del punt de vista de l'origen de la seva riquesa, era una ciutat plenament integrada en el camp circumdant: l'aclaparador pes específic de la riquesa immoble i la condició sòcio-professional majoritàriament primària dels seus habitants demostren ben clarament que la terra era la principal font de la seva riquesa $\mathrm{i}$ acaben completant $\mathrm{i}$ corroborant la visió general delineada.

Si bé la vila s'ocupava bàsicament en el sector agropecuari, hi havia, però, un barri (el quarter de la Plaça) que progressivament anava adquirint una certa especialització funcional en la manufactura i, sobretot, en el terciari. Aquesta especialització funcional estava directament relacionada amb el paper de centre-ciutat desenvolupat per aquest quarter. En una societat totalment jeràrquica com la feudal, la concentració en aquest barri de tots els leit-motivs simbòlics (castell, paeria i església) era, sens dubte, el puntal d'atracció de les categories professionals econòmicament més potentades (comerciants, professions liberals, etc.) i la base explicativa de la seva configuració com a centre de la vila. En contra d'allò a què ens té acostumats el capitalisme industrial, a la ciutat redistributiva medieval no era el poder econòmic qui creava el centreciutat, sinó que el poder simbòlic de la centralitat urbanística era el que atreia el poder econòmic. La importància i l'abast del poder econòmic d'aquest sector terciari que habitava al barri de la Plaça pot ésser avaluat, aproximadament, si tenim en compte que controlava gairebé la meitat o la meitat mateixa de la riquesa de tot el quarter i que la riquesa mitjana de cadascun dels seus membres era molt superior a la riquesa mitjana de tot el quarter $i$ que aquest barri era el més ric, de molt, de la ciutat. La base econòmica concreta d'aquest predomini era, sens dubte, la riquesa immoble de la qual controlava gairebé la meitat de tota la riquesa immoble del quarter. Tots aquests elements ens caracteritzen un patriciat urbà heterogeni ocupat en el terciari (format bàsica- 
ment per comerciants i professions liberals), molt ric -sobretot immobiliàriament - $\mathrm{i}$ concentrat socialment $\mathrm{i}$ urbanística en el centre de la vila.

Des d'un punt de vista general, la situació econòmica del període considerat (1340-1380) pot ésser definida com un moviment cíclic amb una doble conjuntura: el període 1340-1365 seria de crisi fonamentalment caracteritzada per una davallada demogràfica els efectes - a la llarga perjudicials ${ }^{106}$ - de la qual quedarien amagats per l'espiral inflacionària $i$, en canvi, durant el període 1365-1380 són detectables els o alguns dels efectes d'una certa recuperació econòmica.

La crisi econòmica del primer període (1340-1365) va generar un canvi agregat ascendent, és a dir, va haver-hi un cert enriquiment social generalitzat. Sembla com si els recursos econòmics tendissin a una redistribució en els barris agropecuaris (apropiació per diferents mitjans de les terres balderes generades per la mortaldat), mentre que, en el barri més diversificat econòmicament, hi hagué una certa concentració de la riquesa amb manifestacions diverses: els comerciants, davant les penúries, renuncien a la inversió i s'estimen més acumular recursos i atresorar-los en forma de patrimonis immobiliaris, és a dir, diversifiquen el risc (terra, cases i deute públic); els subsectors pelleter $\mathrm{i}$ tèxtil de la manufactura també segueixen aquest comportament $\mathrm{i}$ acumulen béns immobles i, en canvi, les professions liberals acumulen béns mobles (luxe de la llar).

El canvi de la conjuntura -la suposada recuperació del segon període (1365-1380)- generarà, al contrari, un canvi agregat descendent en els quarters agraris (una certa pauperització) i en la riquesa moble dels quarters més diversificats (l'actitud rendista explicaria el fenomen del per què s'inverteix en patrimonis immobiliaris: el canvi agregat ascendent de l'immoble així sembla demostrar-ho). La repercussió, a nivell social, d'aquestes actituds econòmiques es tradueix mitjançant una certa redistribució de la riquesa (sobretot la immoble) que passa a mans dels subsectors pelleter $\mathrm{i}$ tèxtil del secundari en el barri de Montserè, i pelleter i metal lúrgic del secundari i dels comerciants i professions liberals del terciari a la Plaça, encara que la concentració del moble

${ }^{1106}$ Que la Pesta Negra fou un desastre sense precedents ningú no ho nega, però són facilment exagerables els seus efectes econòmics a llarg termini. La Pesta va endur-se, segurament, els malalts, els vells, els ferits i els molt joves, tots aquells que necessiten cura i que res no afegeixen al producte social; altrament, accelera les herències i col-loca joves enèrgics en la gestió dels recursos socials al mateix temps que en redueix les càrregues, la qual cosa produeix una disminució de la nupcialitat $i$ un augment de la taxa de natalitat (D. V. Gl.Ass et D. E. C. Eversley, Population in bistory, London, 1965, pp. 31 i ss). Això explicaria la recuperació econòmica que hem cregut detectar en la darrera dècada de l'època estudiada. 
sembla palesar un canvi: s'acumulen patrimonis monetaris de facil inversió en la manufactura, que la recuperació econòmica sembla encoratjar.

La diferenciació social presenta una major polarització (una més gran separació entre els graus de riquesa) durant la crisi, mentre que la recuperació econòmica coincideix amb una major anivellació social; les estretors de la crisi repercuteixen en un enriquiment dels oligarques, mentre que l'abundor de la recuperació es reparteix socialment d'una manera més uniforme (l'oferiment de llocs de treball per part dels potentats o bé el floriment d'economies -moltes- de petita escala en la manufactura, ho explicarien).

Aquest patriciat urbà que es configura com a oligarquia econòmica i poder polític genera, a nivell espacial i seguint models de comportament fonamentats en el prestigi, un espai social diferenciat; es genera un centre-vila on conviuen els potentats $i$, socialment, hi habita una èlit: primer fonamentada en el poder econòmic del comerç i després en la funció econòmica concreta per part de les professions liberals, sobretot jurídiques. El relleu social i espacial de l'artesanat no acaba de quallar i només és visible econòmicament amb la recuperació $i$, políticament, amb l'accès als càrrecs municipals.

Aquests trets i comportaments semblen indicar-nos que Cervera era, a mitjan segle XIV, una d'aquelles ciutats petites de mercat, que deia Hilton, però havia aconseguit erigir-se en centre comercial-manufacturer de la seva rodalia; altrament, és detectable com, durant el segon període, la preponderància econòmica i el domini social i polític dels comerciants va deixant pas a un doble fenomen: els comerciants esdevenen, conjuntament amb les professions liberals, grans propietaris de terres i altres béns immobles, allunyant-se -desplaçats per l'empenta dels menestrals- de l'activitat productiva i comercial i atansant-se prou facilment als comportaments econòmics rendistes dels terratinents feudals i aproximant-se, segurament també, a les seves actituds socials i polítiques. De manera general, doncs, podem afirmar que, a partir dels resultats de la nostra observació, el model proposat per Nell queda globalment verificat i que, malgrat algunes petites diferències sobretot de grau, l'evolució sòcio-econòmica de l'èlit ciutadana de Cervera encaixa perfectament amb els seus postulats.

En definitiva, Cervera no era pas una illa no-feudal, sinó més aviat la perllongació d'unes formes de vida, d'uns interessos i cultura prou integrats en el sistema feudal i que, només a nivell funcional, va desenvolupar-se com un centre de gestió i comers per una rodalia comarcal plenament feudal. 


\section{RÉSUMÉ}

À partir de l'étude micro-historique d'une ville moyenne à l'intérieur de la Catalogne, il s'agit de Cervera, et en se basant sur l'analyse d'une source fiscale (Manifest), l'article prétend étudier le caractère et le rôle joué par une ville à l'époque féodale et, plus spécialement, pendant sa première crise générale, c'est-à-dire, pendant la deuxième moitié du XIV $V^{\text {twe }}$ siècle. Mise à part l'application des exposés théoriques d'Hilton ainsi que de l'hypothèse de travail de Nell, le travail se base principalement sur l'étude de la structure socio-économique et professionnelle, plus spécialement celle du patriciat urbain, pour démontrer comment la ville a été la prolongation sociale et économique de la féodalité avoisinante et, au moins au niveau fonctionnel, a joué le rôle de centre de gestion et de commerce des environs ruraux.

Au niveau socio-économique et professionnel et tout au long de la période examinée, on peut apprécier une tendance au changement. L'élite urbaine composée principalement par des commerçants évolue vers une composition plus hétérogène, dominée par un mélange de professions libérales juridiques et artisanales.

Sur le plan urbanistique, on peut remarquer la formation, à partir de schémas de conception de ce que représente le prestige social, d'un centre ville où vont vivre tous les gens fortunés et qui deviendra, ainsi, la zone résidentielle de cette élite urbaine.

\section{SUMMARY}

The purpose of the article is to study the character and the role played by a city during the Middle Ages and, more precisely, during the first general crisis, which means during the second half of the XIV't1 century. We will do this through a micro-historical study of an average town in the inner part of Catalonia -the name of the village is Cervera-, and basing ourselves on the analysis os a fiscal source (Manifest) Beside the application of Hilton's theoretical accounts and Nell's work hypothesis, the article is mainly based on the study of the socio-economic and professional structure and, more precisely, that of the urban patricians. The aim is to prove how the village has been the social and economic prolongation of the neighbouring feudality and how, at least at a functional level, it has played the role of centre of management and commerce for the rural surroundings.

At a socio-economic and professional level, and during the whole period examined, we can appreciate a trend to changes. The urban elite, mainly composed by tradesmen evolves towards a more heterogeneous composition, dominated by a mixture of juridic and craft liberal professions.

Referring to urban topics, we observe the formation, based on social prestige, of a city centre where all the rich families went to leave and that became a residential zone for the urban elite. 


\section{APÈNDIX GRÀFIC}

FIGURA 1

CATEGORIES SÒCIO-PROFESSIONALS UTILITZADES. Llegenda i abreviatures

I PRIMÀRIES: hortolà, llaurador.

2 SECUNDÀRIES: arquejador, argiador, assaonador, bainer, ballester, baster, blanquer, bosser, calderer, candeler, corder, cotoner, cuirater, draper, espaser, ferrer, flassader, forner, frener, fuster, guixer, juponer, lavador, levador, llaner, manyà, menestalt, menestral, mercer, paraire, peller, pellicer, pintor, piquer, propunter, sabater, sastre, seder, seller, teixidor, teuler.

3 TERCIÀRIES: 3.1. = Professions liberals: apotecari, barber, cirurgià, escrivà, físic, hostaler, joglar, mestre, notari, procurador de plets, savi. 3.2. = Església: tonsurat, frare, rector. 3.3. = Administració civil: carceler, missatger, quester, saig. 3.4. = Comerf: carnicer, corredor, especier, mercader. 3.5 $=$ Transport: menader, mulner, muler. 3.6. = Altres: cavaller, ciutadà de Barcelona, donzell, senyor.

4 SENSE PROFESSIÓ: aventurer, convers, veïnatge, indeterminats.

(Per al quadre de les migracions professionals:)

$\mathrm{A}=$ Pagesia; $\mathrm{Ba}=$ Tèxtil; $\mathrm{Bb}=$ Pell; $\mathrm{Bc}=$ Metall; $\mathbf{B d}=$ Construcció;

$\mathrm{Be}=$ Altres menestralies; $\mathrm{C} a=$ Professions liberals;

$\mathrm{Cb}=$ Església; $\mathrm{C} c=$ Administració civil; $\mathrm{Cd}=\mathrm{Comer}$;

$\mathrm{Ce}=$ Transports; $\mathrm{Cf}=$ Feudals. 


\section{FIGURA 2}

CARRERS I QUARTERS. Llegenda i abreviatures

Carrers:

Quarter de Cap Corral $(\mathrm{CC}=1)$

$11 \mathrm{~B}$

Bassa del Corral,

12 DPA

Dins del Portal d'Agramunt

13 FPA

Fora del Portal d'Agramunt

14 DPO

Dins del Portal d'Oluja

$15 \mathrm{FPO}$

Fora del Portal d'Oluja

16 DPSA

Dins del Portal de Santa Anna

$17 \mathrm{PO}$

Plaça de l'Om

18 CDSA

Carrer de davant de Sant Antoni

Quarter de Framenors $(\mathrm{FM}=2)$

$21 \mathrm{AB} \quad$ Abeurador

$22 \mathrm{~B}$

Carrer de Barcelona

$23 \mathrm{P}$

Pexera

$24 \mathrm{D}$

Desconegut

Quarter de Montserè $(\mathrm{M}=3)$

$31 \mathrm{CA}$

Carrer de l'Abadia

32 FPVA

Fora del Portal de la Vall

$3.3 \mathrm{PV}$

$34 \mathrm{~B}$

Plaça Vella

$35 \mathrm{BS}$

Cap del carrer de Barcelona

$36 \mathrm{BSC}$

Carrer de Buidassacs

37 RON

Buada sota el Castell

Vall de Roncau

Quarter de la Plaça $(\mathrm{P}=4)$

41 DPV Dins del Portal de Vilanova

42 PFV Fora del Portal de Vilanova

4.3 GJV Grasses de Jaume Vall

44 HSJ Hospital de Sant Joan

$45 \mathrm{P}$

La Plaça

$46 \mathrm{CV}$

Coma d'en Vilagrassa

Call Jueu $(C J=5)$

50) D Desconegut 


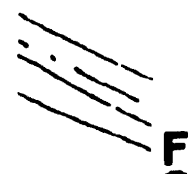

FIGURA 3.-

CERVERA. SEGLE XIV. i quarters 1 carrers.

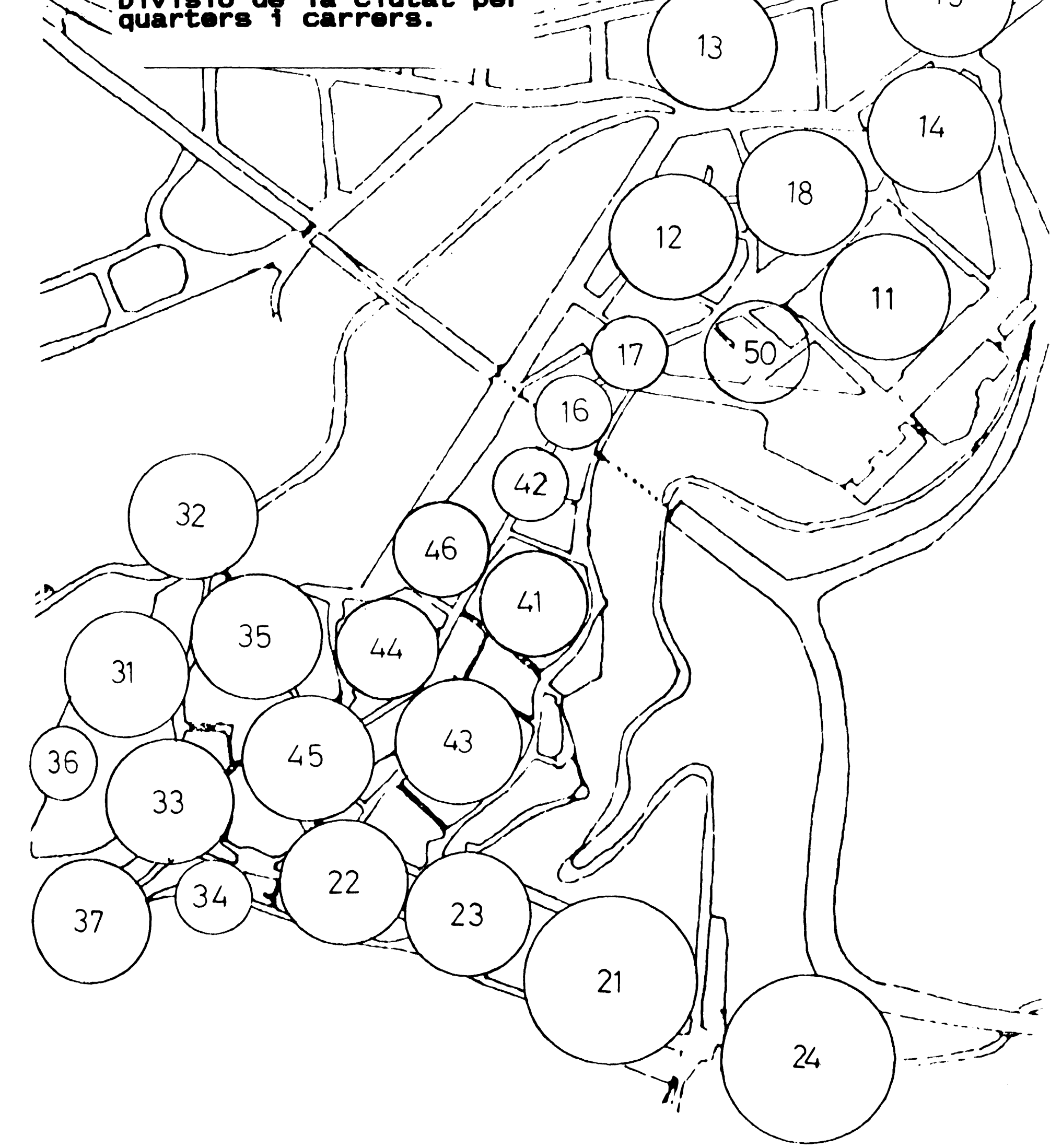




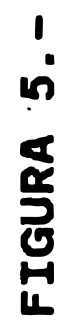

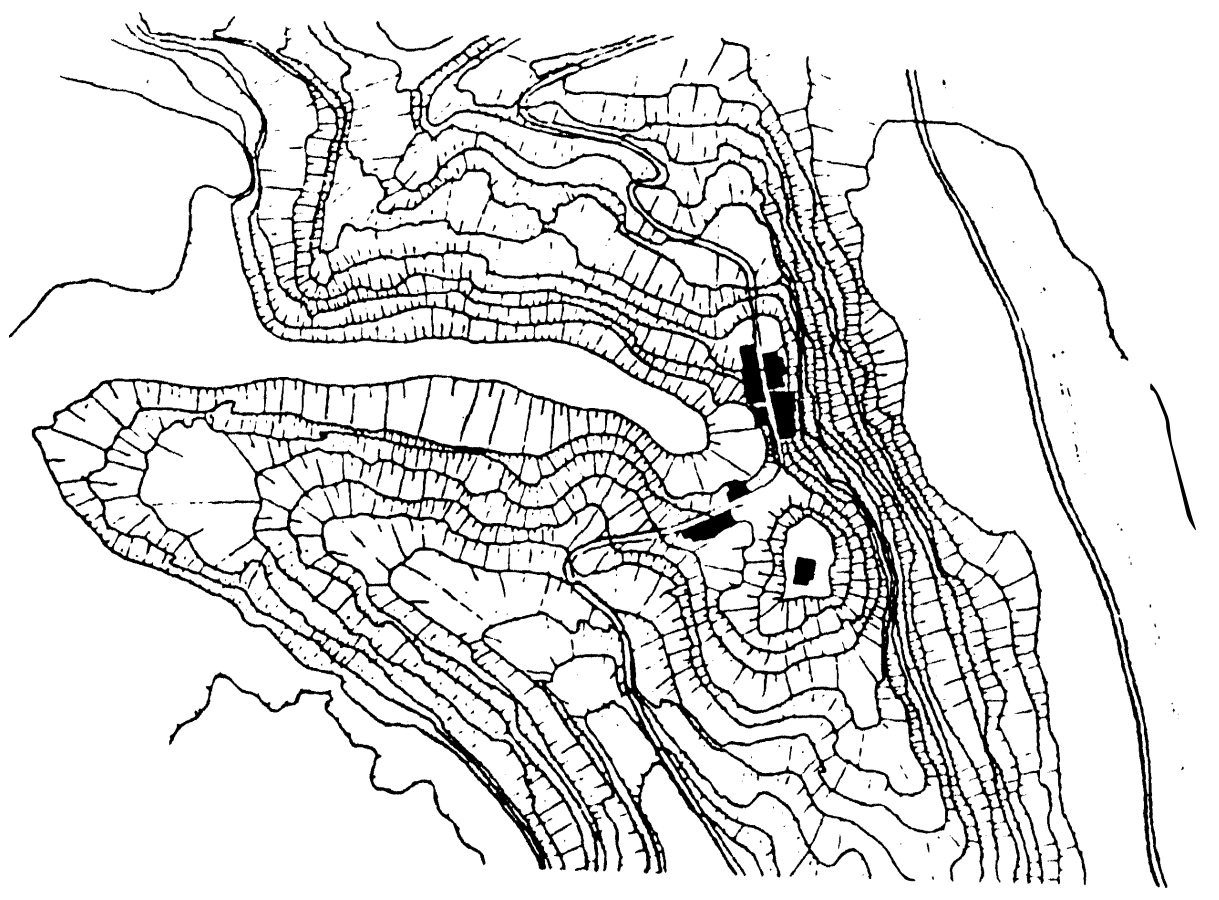

0
0
8
8
8
8
8
8
8
8
8
8
8
8
8
8

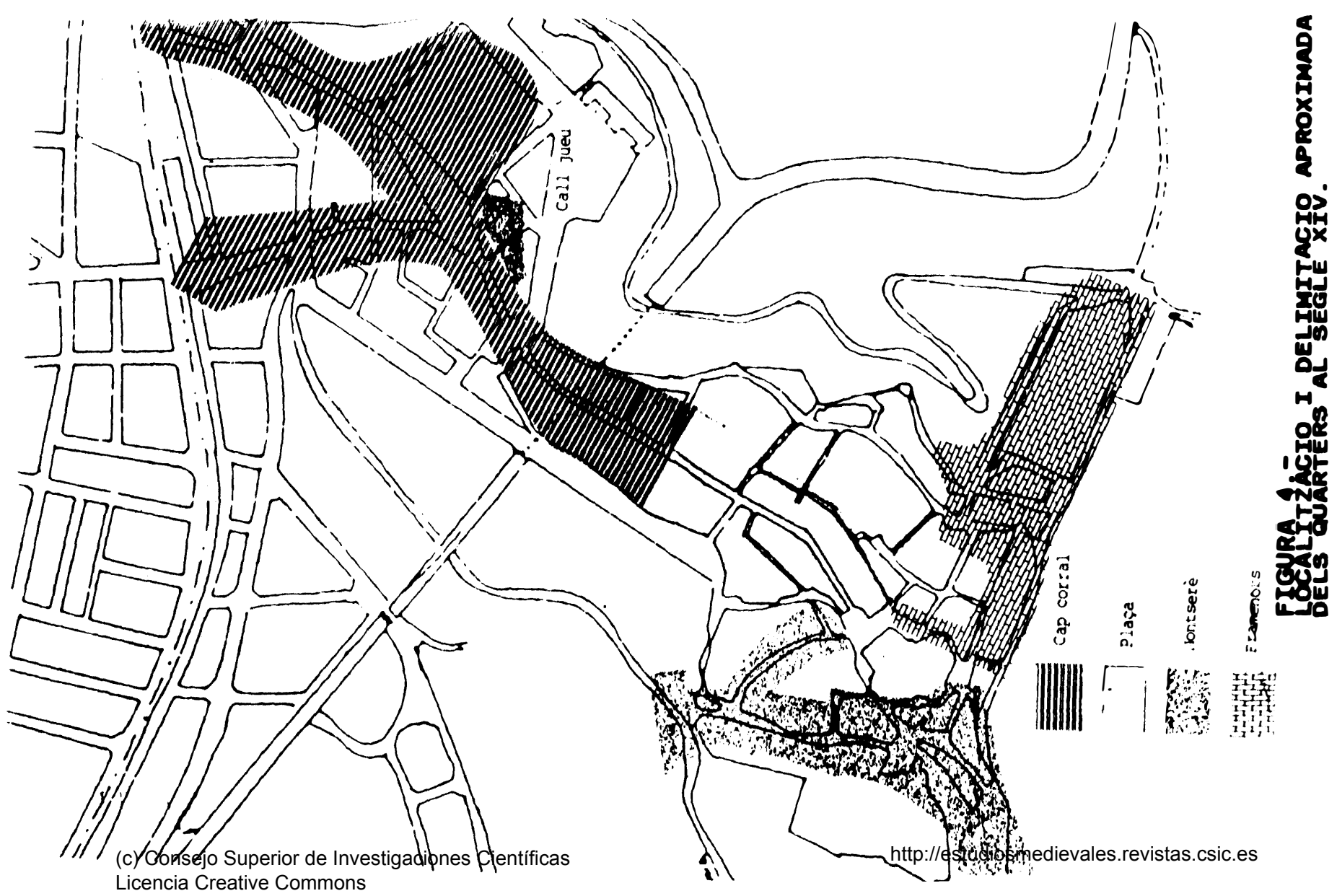

Reconocimiento 4.0 Internacional (CC BY 4.0) 

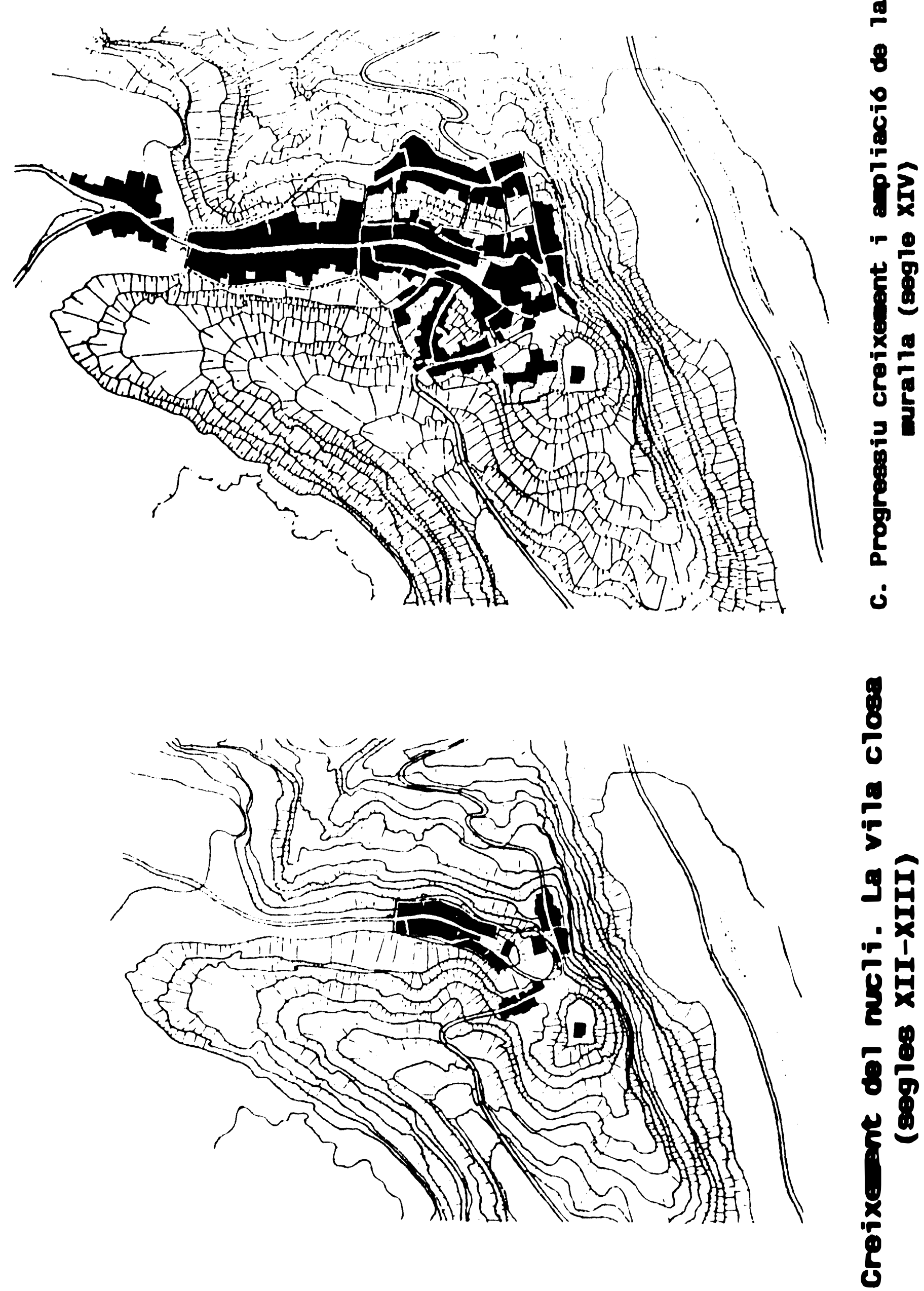
FIGURA 6 -

\section{LA RIQUÉśa A CERVERA AL SEGLE XIV. UNA APROXIMACIO ESTADISTICA.}

\begin{tabular}{|c|c|c|c|c|c|c|c|c|c|}
\hline \multirow{2}{*}{$\begin{array}{l}\text { TIPUS } \\
\text { DE } \\
\text { RIQUESA }\end{array}$} & QUAKTER & $\propto$ & 1 & $\bullet$ & M & $\infty$ & PM: & $M$ & $P$ \\
\hline & ANY & 1360 & 1362 & 1366 & 1366 & 1360 & 3375 & 1370 & 1102 \\
\hline \multirow{8}{*}{$\begin{array}{l}\text { RQQUESA } \\
\text { TOTAL }\end{array}$} & MANIFESTANTS & 333 & 223 & 10 & 152 & 234 & 190 & 218 & 176 \\
\hline & 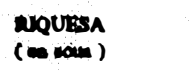 & 412018 & 1025050 & 120007 & solese & 202020 & 567590 & sotri & 1171490 \\
\hline & MTrJaNa & 500,50 & xos,es & 1113,37 & 643,56 & 1557,06 & $30, \pi$ & 593,36 & 2796,40 \\
\hline & Mrrsa & 1207,24 & 4500,67 & 6754,61 & 3094,50 & 3604,15 & 2052,25 & $2320, \infty 0$ & $\cos 6,24$ \\
\hline & $\begin{array}{l}\text { DESVIncas } \\
\text { TPACA }\end{array}$ & 2009,67 & 7928,6 & 12959,67 & 7305,66 & 47283 & 4751,99 & 3344,93 & 10357,09 \\
\hline & $\begin{array}{l}\text { SEOON } \\
\text { COEARCLEN } \\
\text { LUDX reNRSON }\end{array}$ & 1,0518 & 1,0324 & 1,3058 & 1,3369 & 1,2100 & 1,3393 & 1,5566 & 1,1100 \\
\hline & $\begin{array}{l}\text { COEPICIEN } \\
\text { valuacis }\end{array}$ & 100 & 17 & 191 & 107 & 136 & 166 & 143 & Iss \\
\hline & ADEX DE ONI & 0,0017 & 0,6030 & 0,6076 & 0,6719 & 0,5223 & 0.6202 & 0,5725 & 0,0094 \\
\hline \multirow[t]{7}{*}{$\begin{array}{l}\text { RUQUESA } \\
\text { DMCOBLER }\end{array}$} & $\begin{array}{l}\text { RQUESAA } \\
\text { (a) }\end{array}$ & 319143 & 854058 & 96000 & 470020 & $\pi 00053$ & 453235 & 41764 & 91800 \\
\hline & MTIIANA & 436.13 & 1367,30 & 2333,20 & 1211,34 & $2 \operatorname{sen}, 20$ & 1225,74 & 1128,56 & 3158,06 \\
\hline & MUTJA & 950,30 & 3020,05 & 3141,91 & 3118,55 & 20011,39 & $2 n, 56$ & 2020,4 & 5521,59 \\
\hline & $\begin{array}{l}\text { Desinat } \\
\text { resca }\end{array}$ & ISSO & $\operatorname{ssn} 2,16$ & 90.27 & $\operatorname{sens,37}$ & 4107,76 & 3675,51 & 27200,18 & 8067,67 \\
\hline & $\begin{array}{l}\text { IBOON } \\
\text { COEPICIENT } \\
\text { EUD PENRSON }\end{array}$ & 1,0010 & 1,1223 & 0,2474 & 0,0575 & 0,2000 & 0,28205 & 0,9750 & 0,7006 \\
\hline & ADEXX DH ONI & 0,0005 & 0,0002 & 0,6762 & 0,0700 & 0,5126 & 0,6170 & 0,5550 & 0,0362 \\
\hline & $\begin{array}{l}\text { MOPORCHO } \\
\text { RQPUBSA TOTNL. }\end{array}$ & $n, 4$ & $\mathbf{m . 4}$ & 76,2 & $\infty, 07$ & $m, 4$ & $x 9,85$ & 17 & $\bullet$ \\
\hline \multirow[t]{8}{*}{$\begin{array}{l}\text { RQQUESA } \\
\text { MONLR }\end{array}$} & 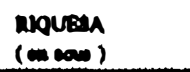 & 02075 & 171001 & 303212 & $11 \pi m$ & 120175 & 114364 & Coss? & 190000 \\
\hline & MTrONNA & 201,10 & 30.40 & 412,25 & 333,30 & 354,15 & 322,05 & 200,00 & 306,05 \\
\hline & MIma & $2 n, 25$ & $\operatorname{xan} 2$ & 1012,00 & $\pi s, 94$ & 20.75 & 574,60 & so2,ss & 1134,65 \\
\hline & $\begin{array}{l}\text { Desnicy } \\
\text { rexca }\end{array}$ & $\operatorname{cos,31}$ & 1753,07 & 0260,06 & 1600,16 & 1034,30 & 1451,10 & $\| \omega_{3}, 5$ & 3009,61 \\
\hline & $\begin{array}{l}\text { socon } \\
\text { coeprouent } \\
\text { and revenon }\end{array}$ & 0.0025 & 0,7156 & 0,0241 & 0,7000 & 0,5400 & 0,5202 & 0,0005 & 0,7457 \\
\hline & NDEX DE ONI & 0,7003 & $0.7 \mathrm{~ns}$ & 0,00012 & 0.7002 & 0,6714 & 0,7026 & 0,790 & 0,0050 \\
\hline & $\begin{array}{l}\text { conencion } \\
\text { varuas }\end{array}$ & 250 & 20 & 204 & 213 & 190 & 252 & 304 & 27 \\
\hline & 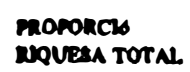 & 2,5 & 10,6 & 23,8 & 19,22 & 19,5 & 20,14 & 12,90 & 17 \\
\hline
\end{tabular}


FIGURA 7

LA DISTRIBUCYO DE LA RIQUESA

EL GRAU DE DESIGUALTAT SOCIAL

DADES ESTAD 1STIQUES de les Corbes de pareto

\begin{tabular}{|c|c|c|c|c|c|c|c|c|c|}
\hline \multirow{2}{*}{$\begin{array}{l}\text { TIPUS DE } \\
\text { RLQUESA }\end{array}$} & QUARTER & $\mathrm{cc}$ & $\mathbf{P}$ & $\mathbf{P}$ & $M$ & cc & FM & $\mathbf{M}$ & $\mathbf{p}$ \\
\hline & ANY & 1300 & 1352 & 1366 & 1366 & 1360 & 1375 & 1378 & 1382 \\
\hline \multirow[t]{5}{*}{$\begin{array}{l}\text { RUQUESA } \\
\text { TOTAL }\end{array}$} & $\begin{array}{l}\text { CONETANT } \\
\text { (VALON A) }\end{array}$ & 122212,53 & 37095,47 & 2479,80 & 43131,81 & 21291,09 & 15147,32 & 16293,10 & 16669,13 \\
\hline & $\begin{array}{l}\text { PENOEart } \\
\text { (VALOR - ) }\end{array}$ & $-1,012030$ & 0,790001 & 0,5906000 & $-0,877660$ & $-0,703322$ & 0,706061 & 0,861402 & 0,602067 \\
\hline & $\begin{array}{l}\text { Cogarciant } \\
\text { Corrathacio } \\
\text { (r) }\end{array}$ & $-0,02022$ & 0,7332200 & 0,7500003 & 0,21309 & 0.879574 & 0,859617 & 0.050930 & 0,020929 \\
\hline & $\begin{array}{l}\text { Colarictiont } \\
\text { DETERMANACL } \\
\left(\boldsymbol{R}^{2}\right)\end{array}$ & 0,960116 & 0,830518 & 0,848324 & 0.860534 & 0,858308 & 0,916011 & 0,895465 & 0,797912 \\
\hline & R' NUSTAT & 0,920155 & 0,728147 & 0,810005 & 0,025667 & 0,811078 & 0,200015 & 0,860620 & 0,747390 \\
\hline \multirow[t]{5}{*}{$\begin{array}{l}\text { RQUESA } \\
\text { DMMOBLE }\end{array}$} & $\begin{array}{l}\text { CONOrANT } \\
\text { (VNLOA A) }\end{array}$ & 400000,96 & 39020,16 & 13003,05 & 8163.74 & $25429 . \pi$ & 23799,06 & 107620,76 & 18382,27 \\
\hline & $\begin{array}{l}\text { PENDONT } \\
\text { (VALOR - })\end{array}$ & $-1,2007$ & $-0,81790$ & 0,676830 & 0,058600 & 0,746610 & $-0, \pi 6384$ & 0,924553 & 0,716486 \\
\hline & 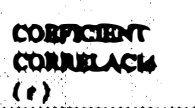 & 0,758039 & 0, rases & 0.221390 & $-0, \operatorname{sen} \pi$ & 0,899391 & 0.853161 & $0, e s w a s e$ & $0, \pi 0002$ \\
\hline & 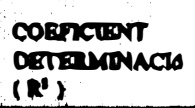 & 0,916413 & 0,42751 & 0,040004 & 0,931004 & 0,052405 & 0,91609 & 0,807430 & 0,020960 \\
\hline & n NUTTAT & 0,000 & 0,000300 & 0,005756 & 0,8000000 & 0,000314 & 0,009197 & $0, \cos 00$ & 0.706211 \\
\hline \multirow[t]{5}{*}{$\begin{array}{l}\text { nousen } \\
\text { Monce }\end{array}$} & $\begin{array}{l}\text { CONTANT } \\
\text { (VALOL A) }\end{array}$ & 142500,02 & $20 m, 40$ & 2007,54 & 35737,36 & 50321,73 & 36731,90 & 27050,93 & louns,so \\
\hline & $\begin{array}{l}\text { PaNDER } \\
\text { ( VNlon - ) }\end{array}$ & $-1,270114$ & $0,02 x=18$ & 0,061020 & $-1,033193$ & $-1,0206$ & $-1,000260$ & $-1,045533$ & 0,705020 \\
\hline & 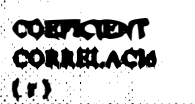 & 0,00007 & 0,6000033 & $0,0 \cos 21$ & 0,670023 & 0,000000 & $-0,591038$ & 0,34201 & 0,61954 \\
\hline & $\frac{\text { compain }}{\left(N^{\prime}\right)}$ & 0,000000 & 0,04737 & 0,204100 & $0,00000 \times 7$ & 0,902339 & 0,050002 & 0,00007 & 0,050000 \\
\hline & ONNTTAT & $0,035 s s 4$ & 0,9250030 & 0,952211 & 0.005200 & 0,800500 & 0,034045 & 0,905610 & 0,20525 \\
\hline
\end{tabular}




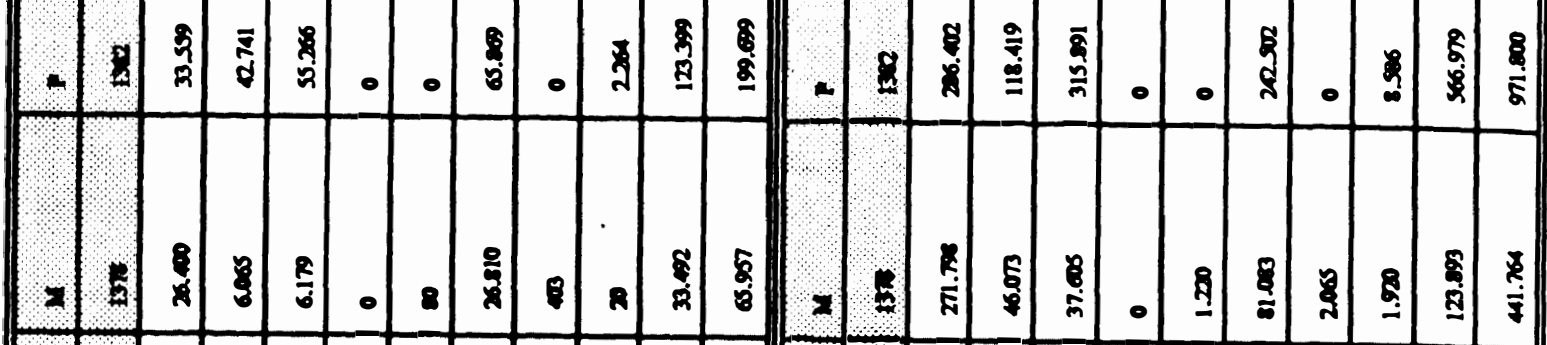

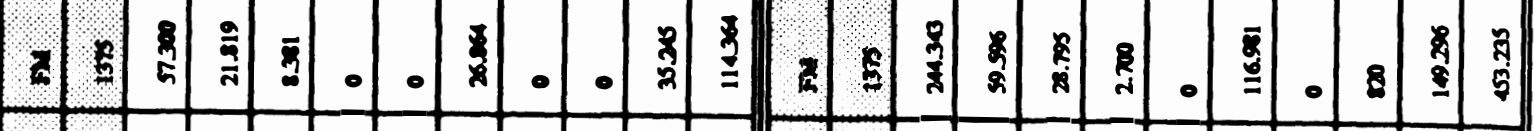

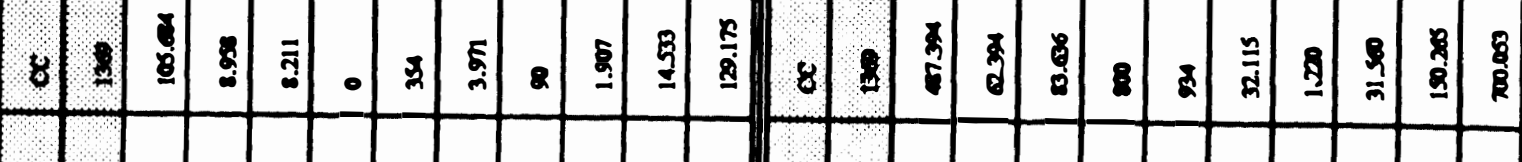

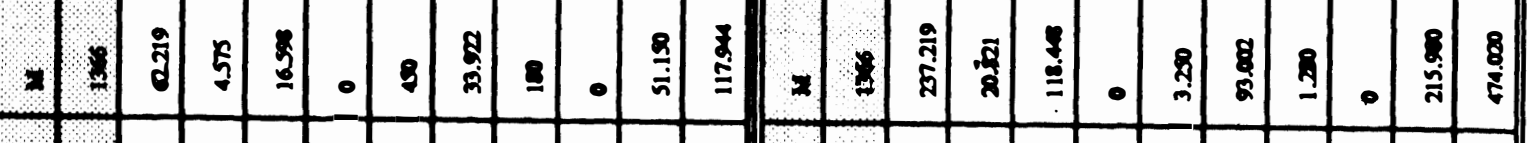

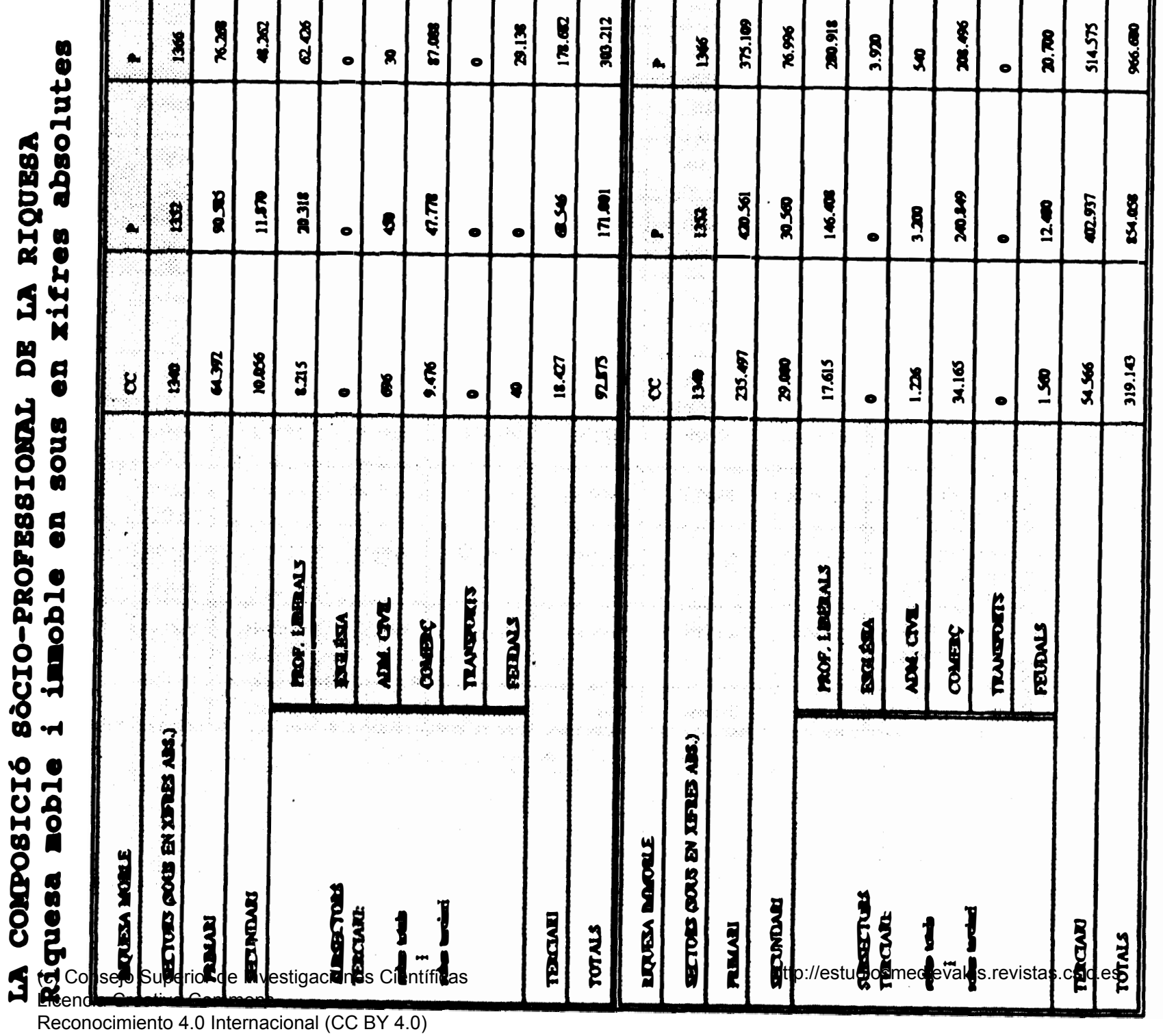




\begin{tabular}{|c|c|c|c|c|c|c|c|c|c|c|c|c|c|c|c|c|c|c|c|c|c|c|}
\hline$A$ & \&1 & $\approx$ & $m$ & \& & 0 & - & A) & - & $\sim$ & $\approx$ & $\underline{\underline{g}}$ & m. & 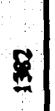 & & $\frac{8}{9}$ & $\begin{array}{l}5 \\
\vdots \\
\bar{m}\end{array}$ & - & & . & 0 & & 莡 \\
\hline$\approx$ & है & $\underline{a}$ & $\bar{m}$ & $r$ & 0 & . & 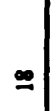 & .1 & -1 & $\approx$ & $\underset{\pi}{*}$ & \pm & 5 & & $\frac{\pi}{\sigma}$ & 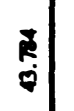 & 。 & & & $\stackrel{8}{9}$ & $\frac{2}{5}$ & $\begin{array}{l}\overline{\tilde{T}} \\
\dot{\xi}\end{array}$ \\
\hline a) & 总 & $\Xi$ & $\approx$ & $n$ & - & 0 & $=1$ & 0 & - & $=1$ & 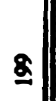 & ฉ & E & $\begin{array}{l}3 \\
\vdots \\
\vdots\end{array}$ & $\stackrel{n}{\square}$ & $\begin{array}{l}\frac{R}{2} \\
\dot{m}\end{array}$ & $\begin{array}{l}\boldsymbol{R} \\
N\end{array}$ & & 罢 & 0 & $\overrightarrow{\underline{z}}$ & $\left|\begin{array}{c}\$ \\
\vdots \\
\vdots\end{array}\right|$ \\
\hline 8 & 8 & $\underline{\mathbf{\Omega}}$ & A) & $=$ & - & -1 & $a$ & -1 & m & 8 & 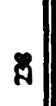 & 8 & 2 & 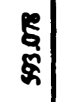 & $\underset{\frac{g}{n}}{\sim}$ & 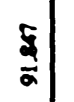 & 8 & $\stackrel{9}{2}$ & 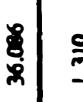 & $\frac{9}{9}$ & & $\mid \begin{array}{l}8 \\
8\end{array}$ \\
\hline य) & 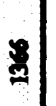 & $\underline{\mathbf{z}}$ & $\simeq$ & $\simeq$ & - & -1 & $=1$ & $\sim$ & - & \& & $\underline{\underline{q}}$ & $x$ & 8 & $\begin{array}{l}3 \\
8\end{array}$ & 芳 & $\begin{array}{l}0 \\
\vdots \\
2 \\
\underline{a}\end{array}$ & 0 & \begin{tabular}{ll}
8 \\
\hdashline
\end{tabular} & 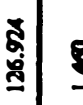 & 0 & $\frac{\Omega}{\delta}$ & $\begin{array}{l}\alpha \\
\bar{\alpha}\end{array}$ \\
\hline a & 2 & $\cong$ & 8 & 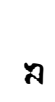 & - & -1 & 8 & - & $\mathrm{m}$ & \& & $\underline{\underline{p}}$ & .1 & 2 & $\begin{array}{l}\text { ह } \\
5\end{array}$ & ম્ & $\begin{array}{l}2 \\
3 \\
2\end{array}$ & క్లి & R & 雨 & 0 & รู & $\mid \begin{array}{l}\mathbf{z} \\
\mathbf{2}\end{array}$ \\
\hline n & 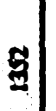 & 2 & $\vec{m}$ & 8 & 0 & -1 & ㅇ & $\circ$ & - & 8 & ถ้ & a & 9 & $\stackrel{\frac{s}{3}}{\bar{n}}$ & 8 & 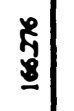 & ○ & 疍 & ही & .08 & $\frac{8}{8}$ & 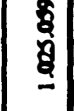 \\
\hline
\end{tabular}

的

.

:

要

5

.

4

믕

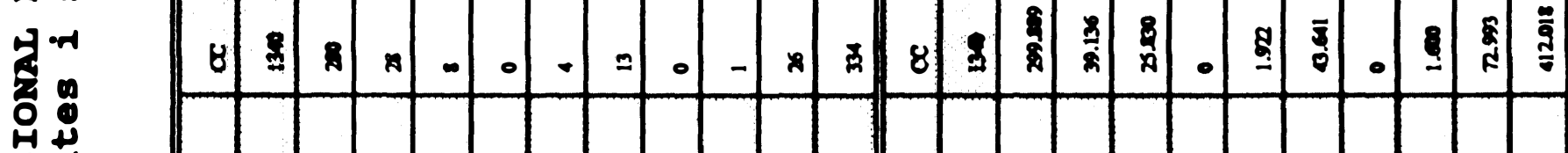

喟

品

홍

\%

1

용

品

品

옹

잉

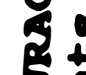

E.

ดे

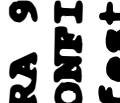

हुํำ 


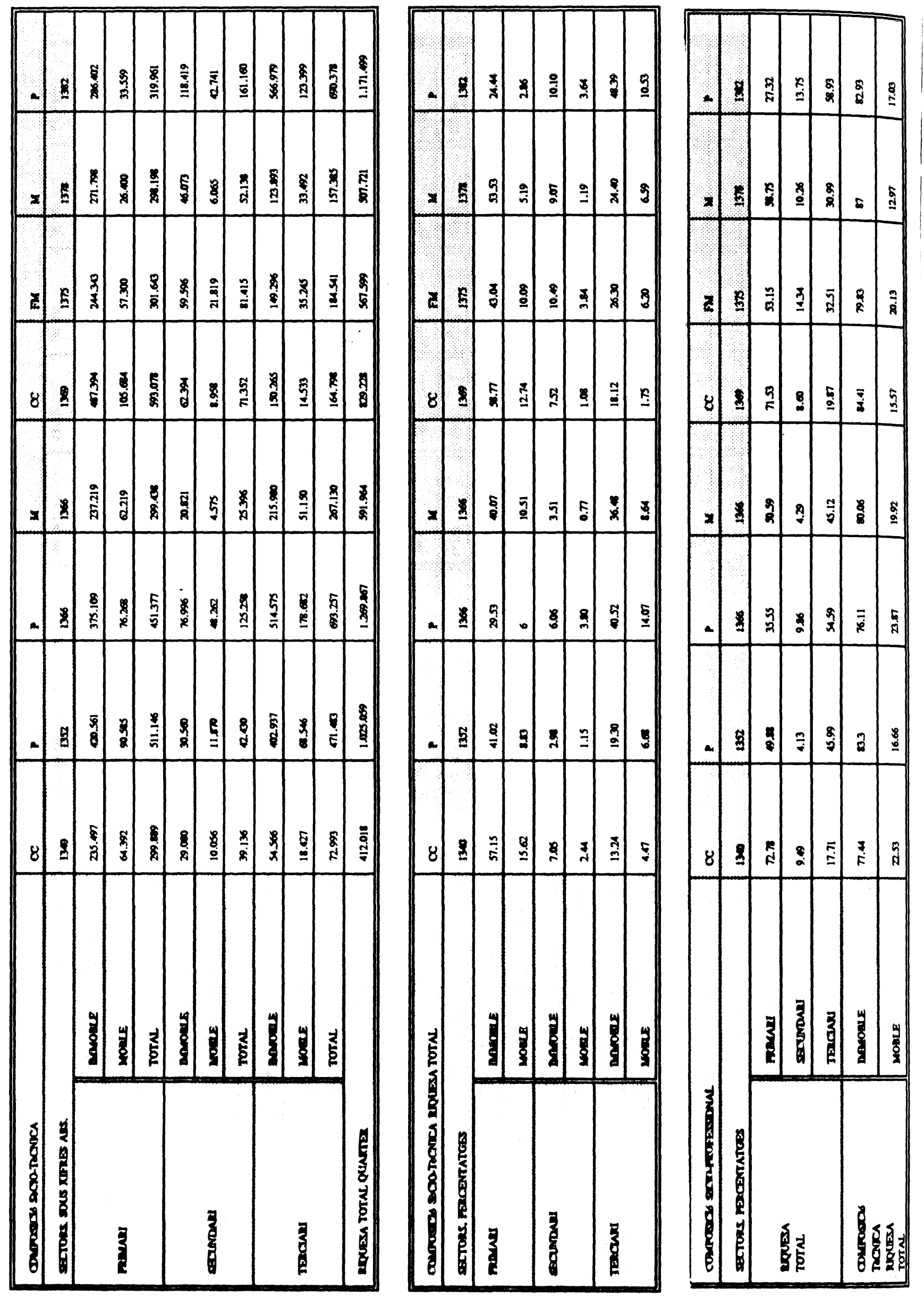

PIGURA 9.

IA CONFIGURACI6 8OCIO-PROFE88IONAL DE IAA RIQUE8A 

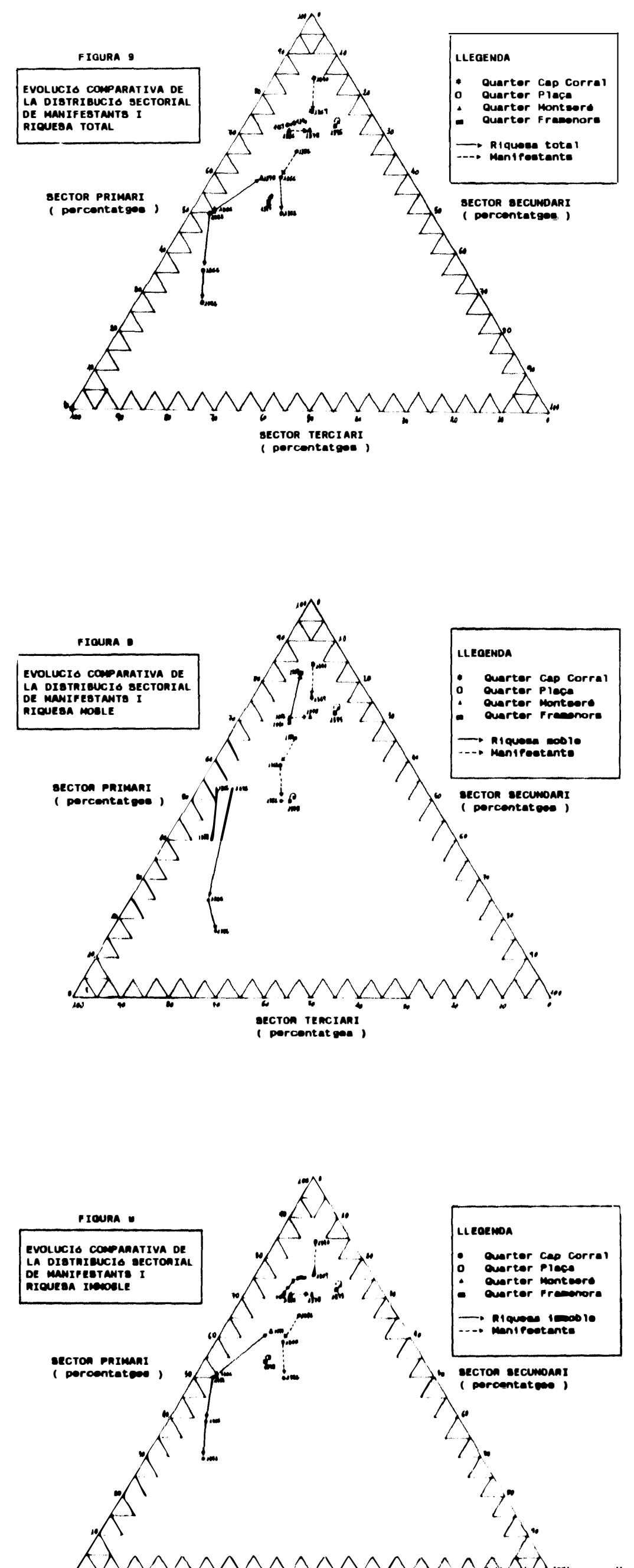

(c) Consejo Superior de Investigaciones Ciếntífica: Licencia Creative Commons 


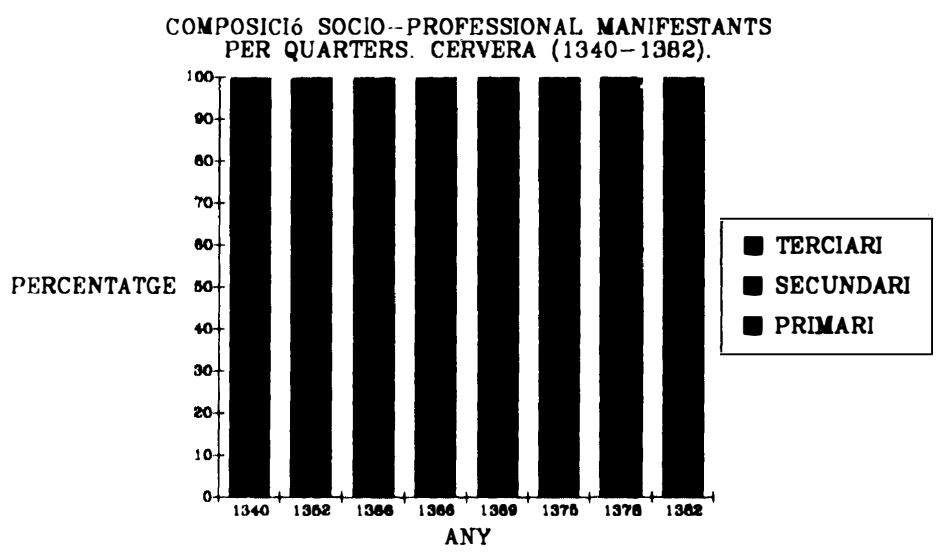

FIQURA :

PROPORCI6 IMNOBLE/MOBLE SECTOR SECUNDARI PER QUARTERS. CERVERA (1340-1382).

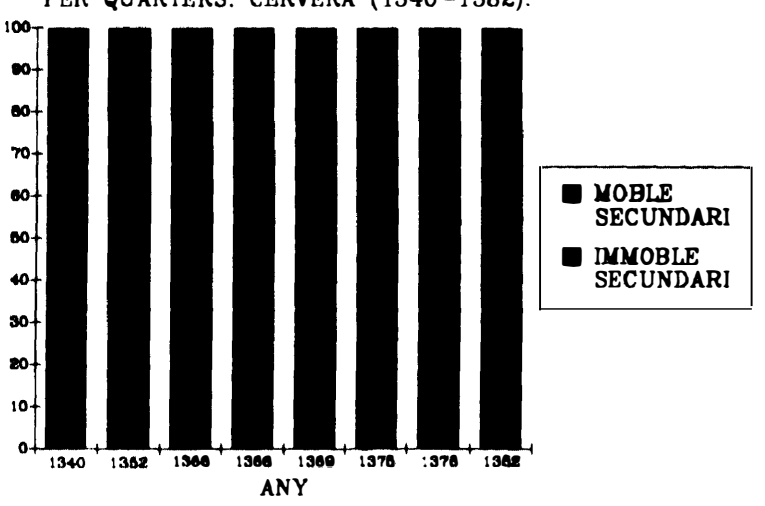

FIOURA

PROPORCI6 INMOBLE/NOBLE SECTOR PRIMAR PER QUARTERS. CERVERA (1340 - 1382).

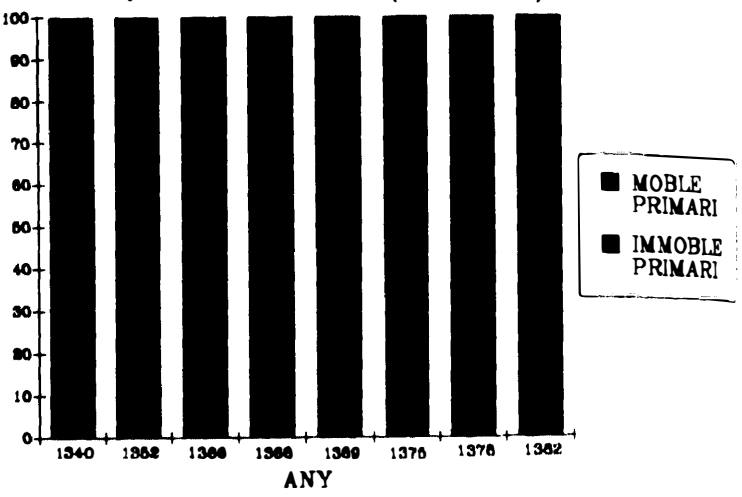

FIOURA

PROPORCI6 IMNOBLE/MOBLE SECTOR TERCIARI PER QUARTERS. CERVERA $(1340-1382)$.

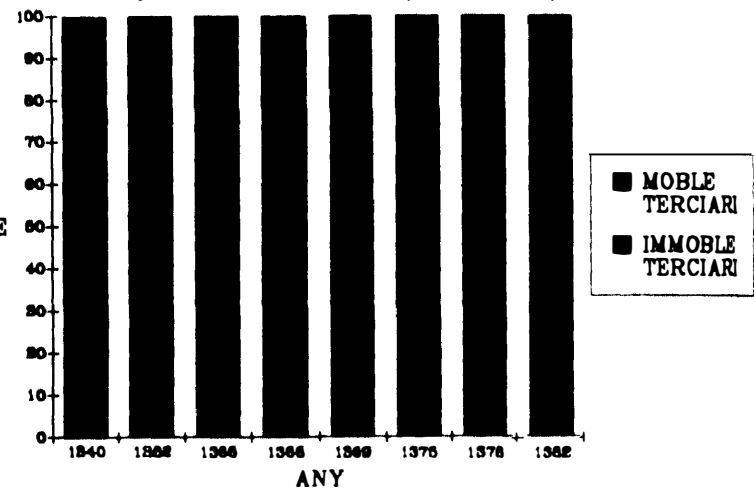

FIGURA 10

LA COMPOSICIO TOCNICA DE LA RICUESA

DADES ESTAD ISTIQUES DE LES REGRESSIONS SIMPLES

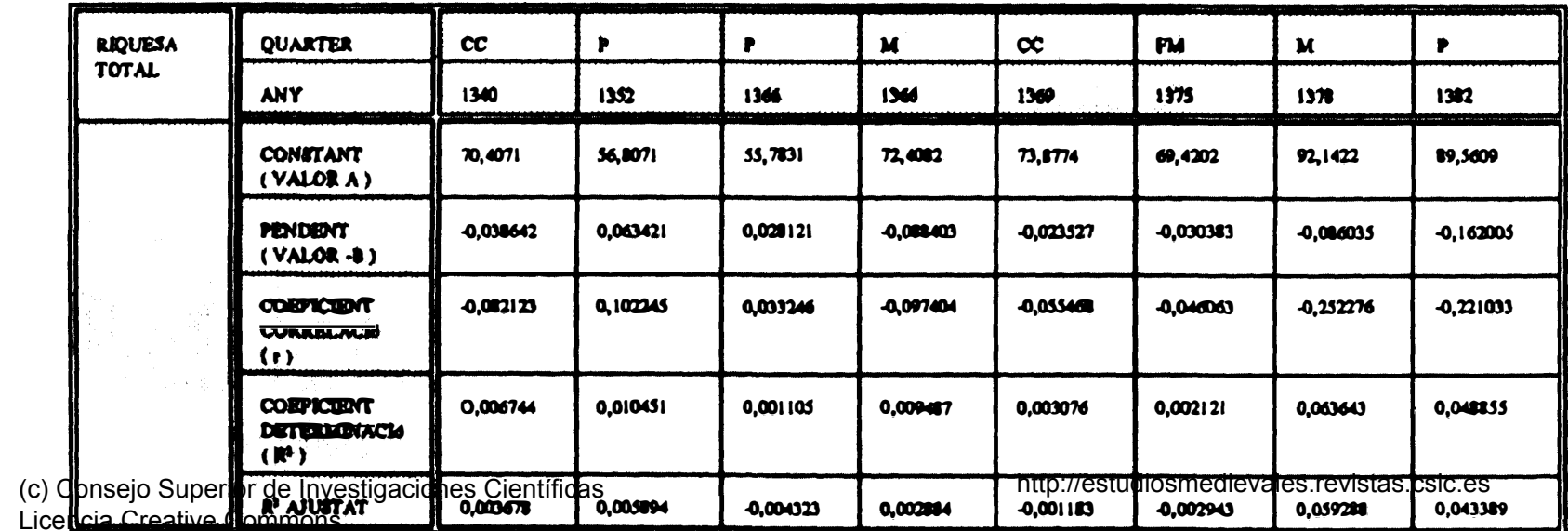




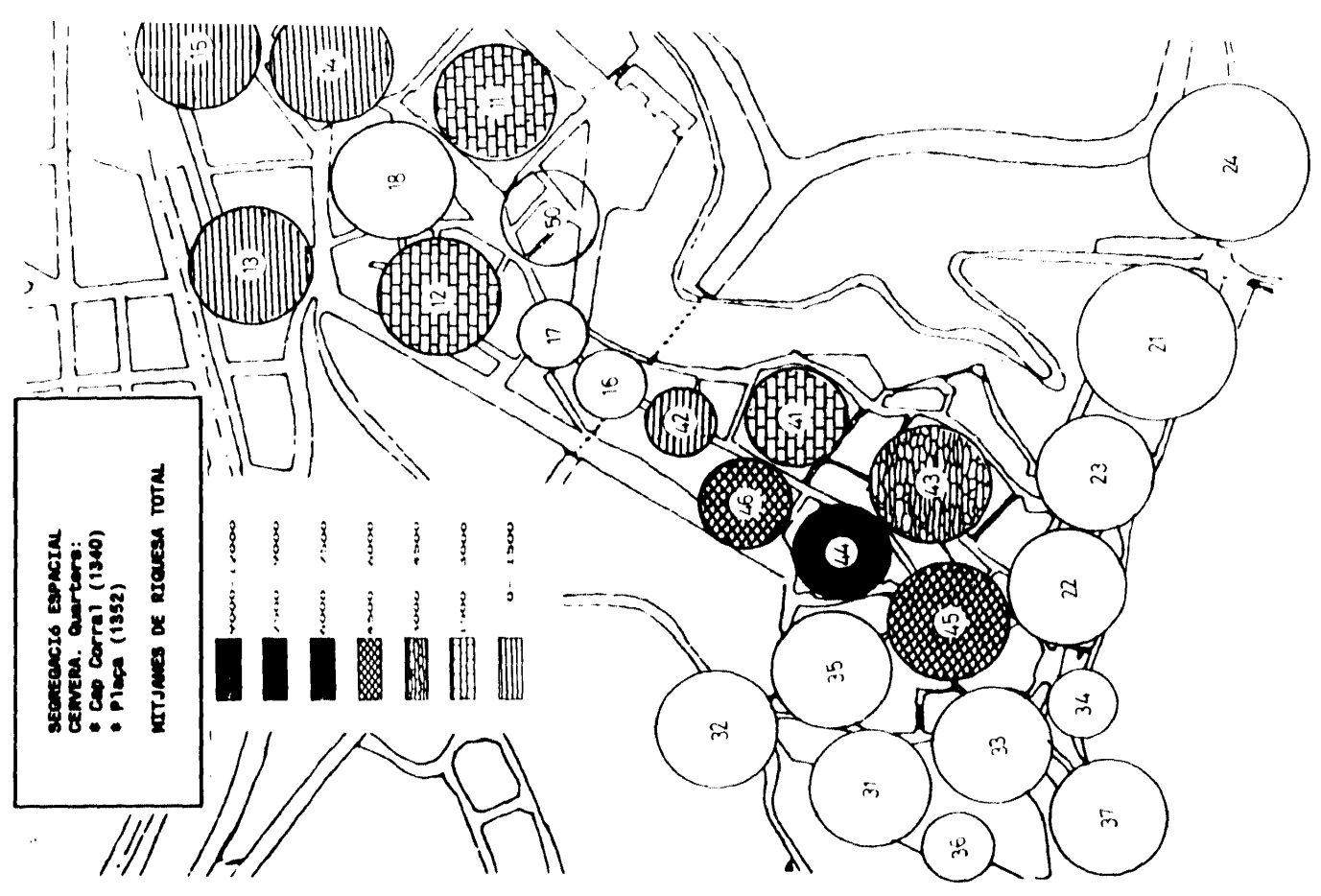

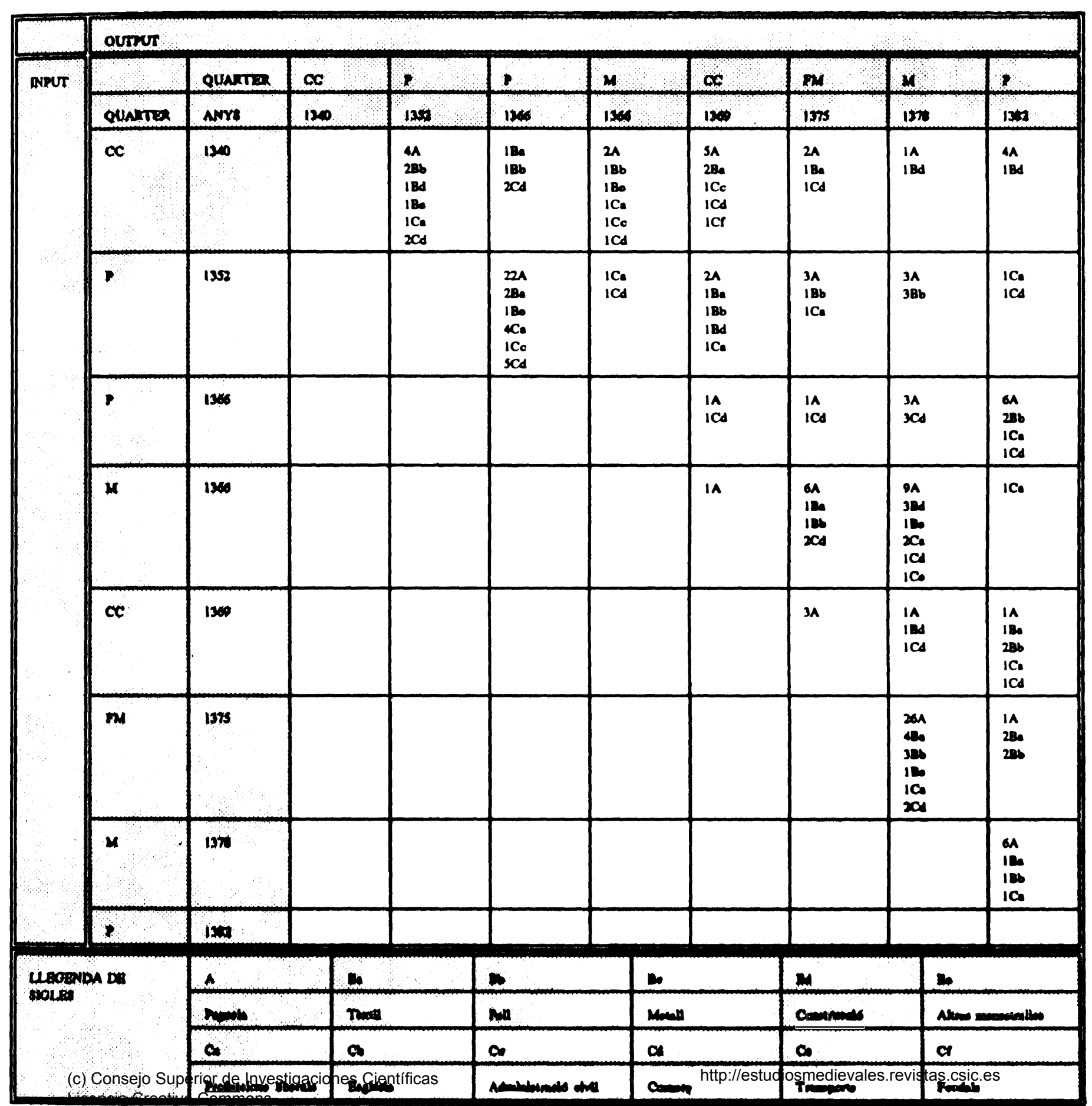



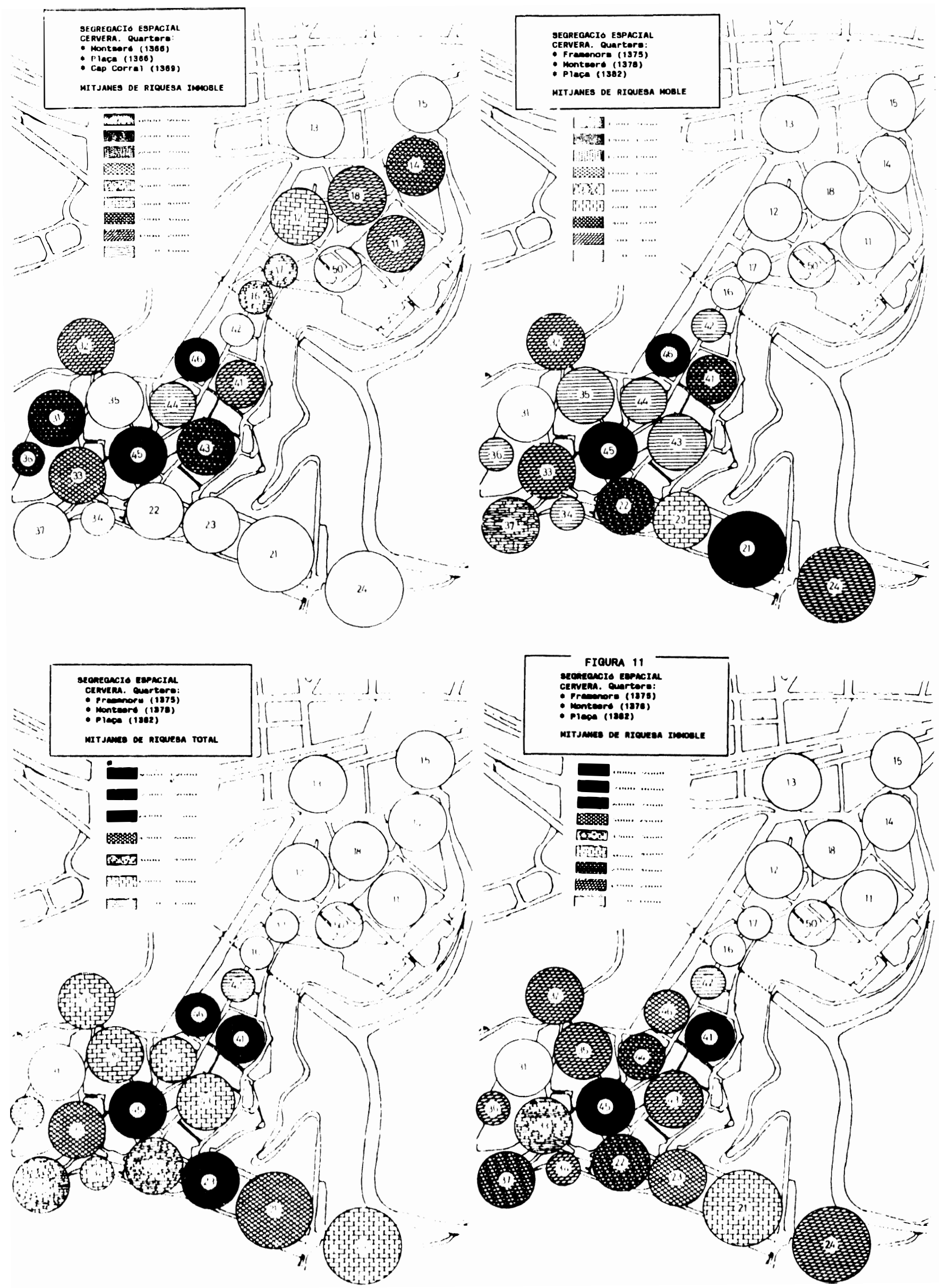

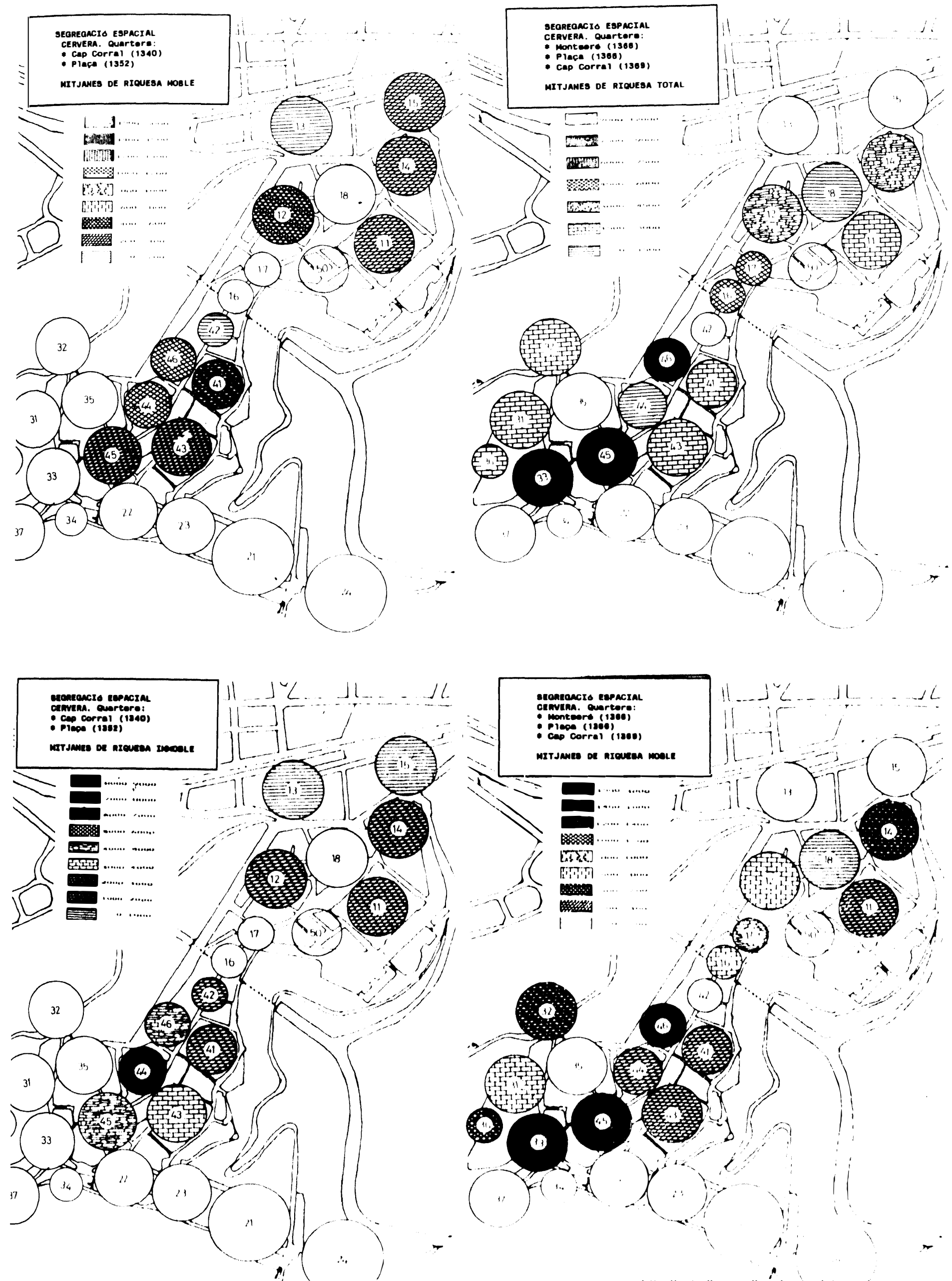

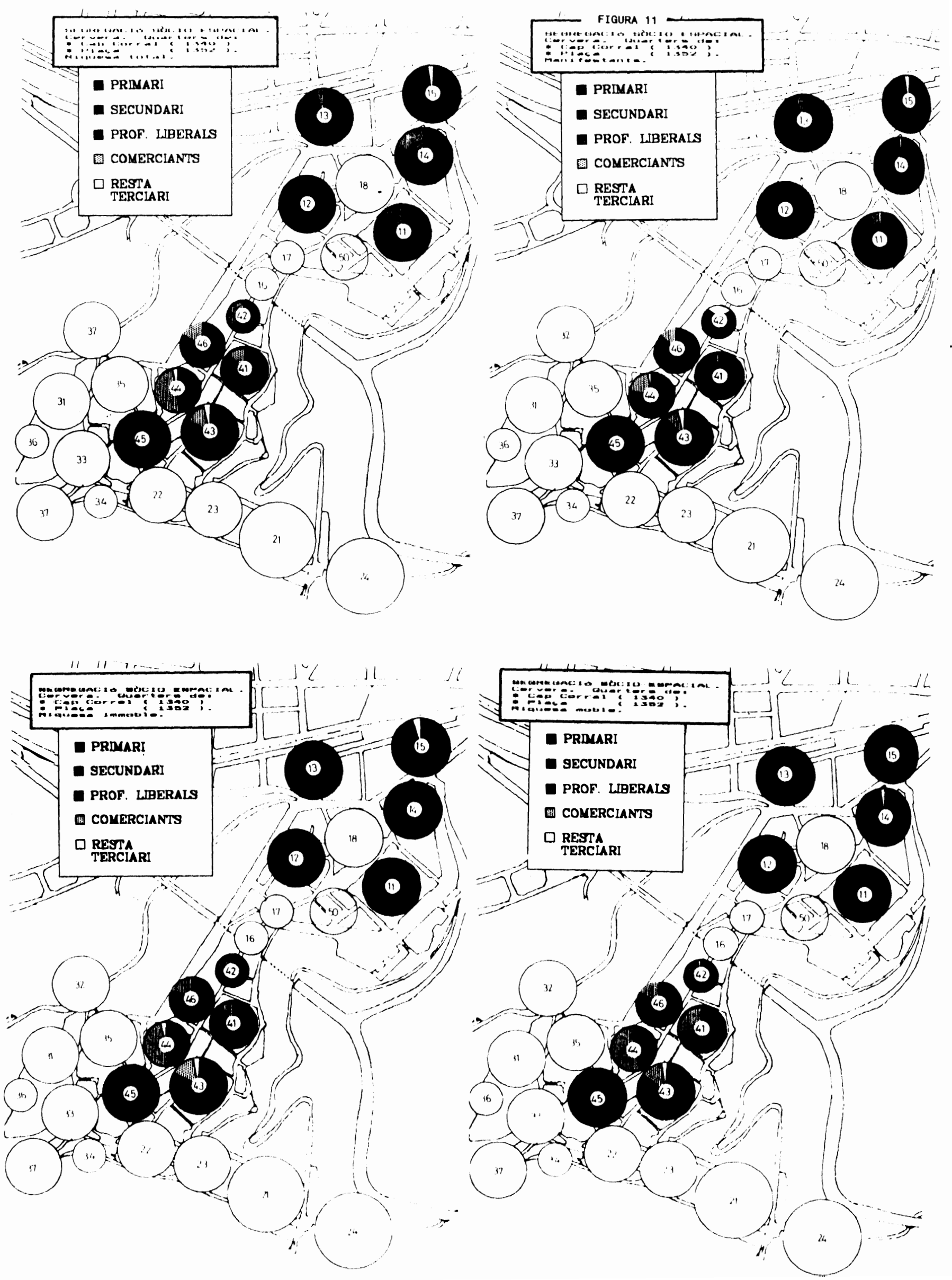

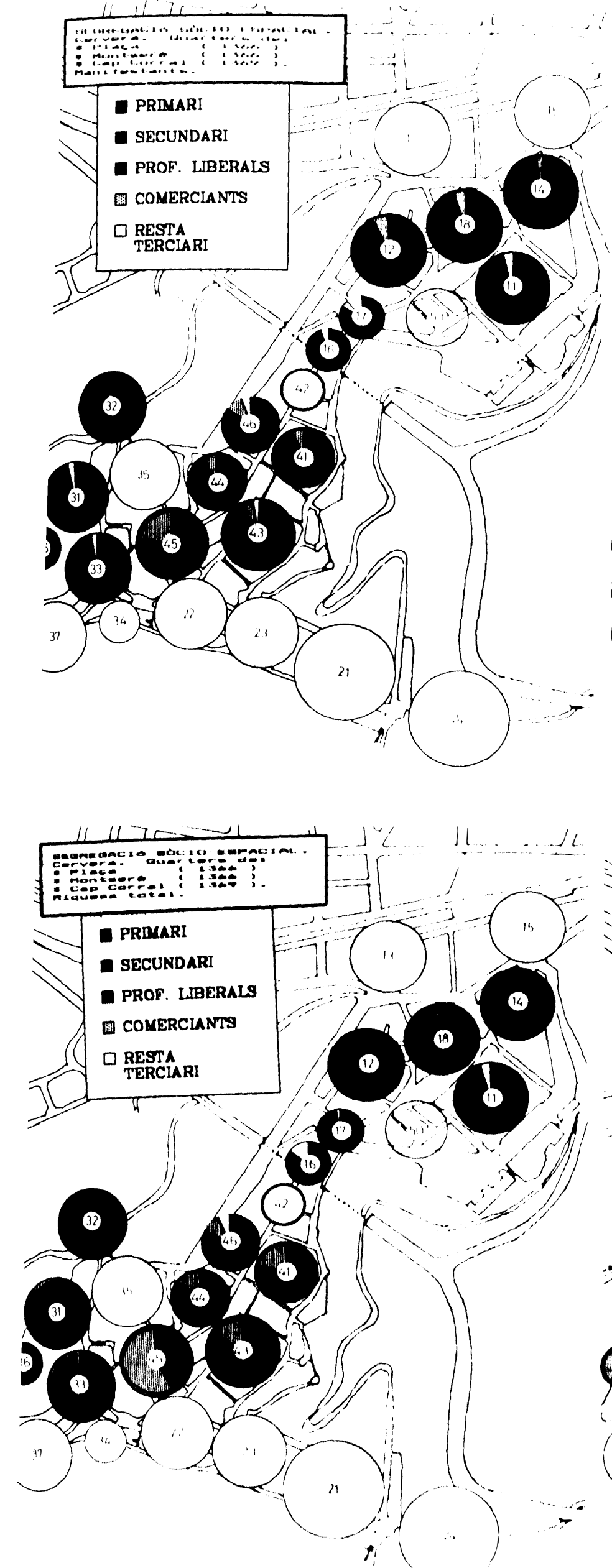

(c) Consejo Superior de Investigaciones Científicas Licencia Creative Commons

Reconocimiento 4.0 Internacional (CC BY 4.0)
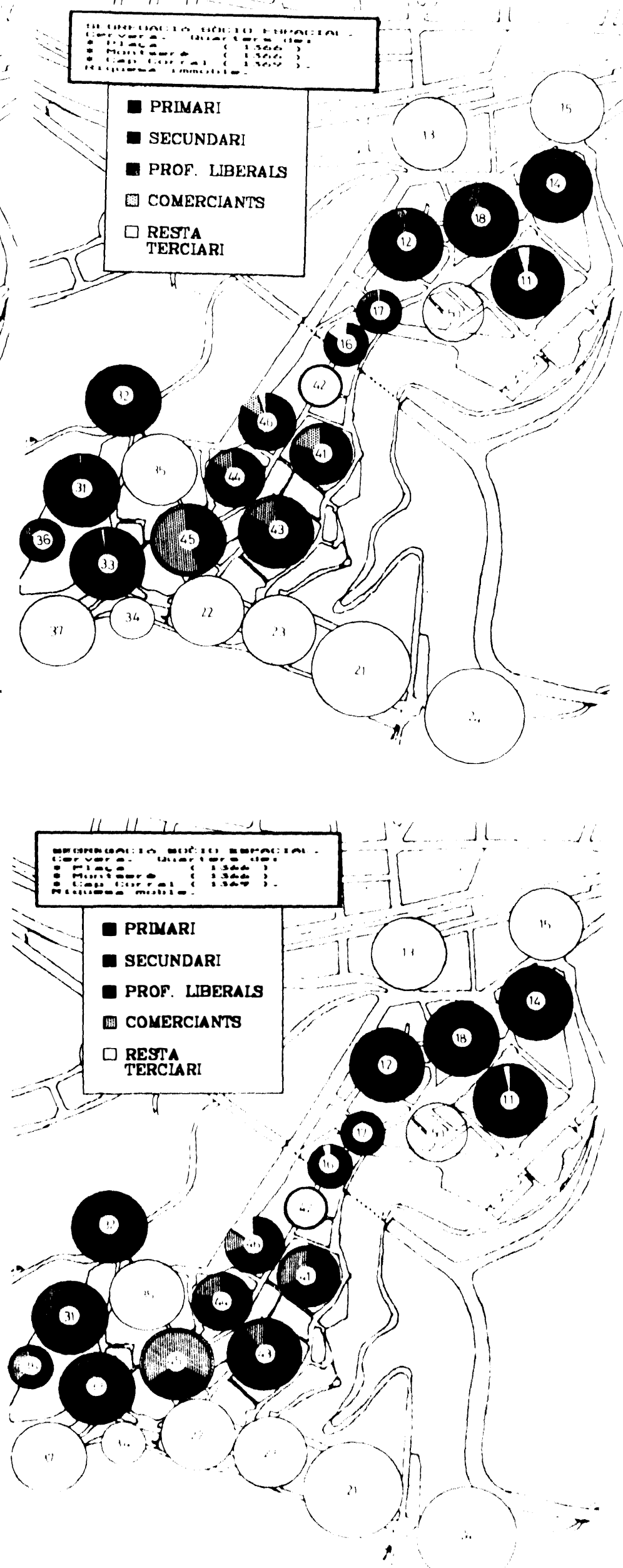

http://estudiosmedievales.revistas.csic.es 

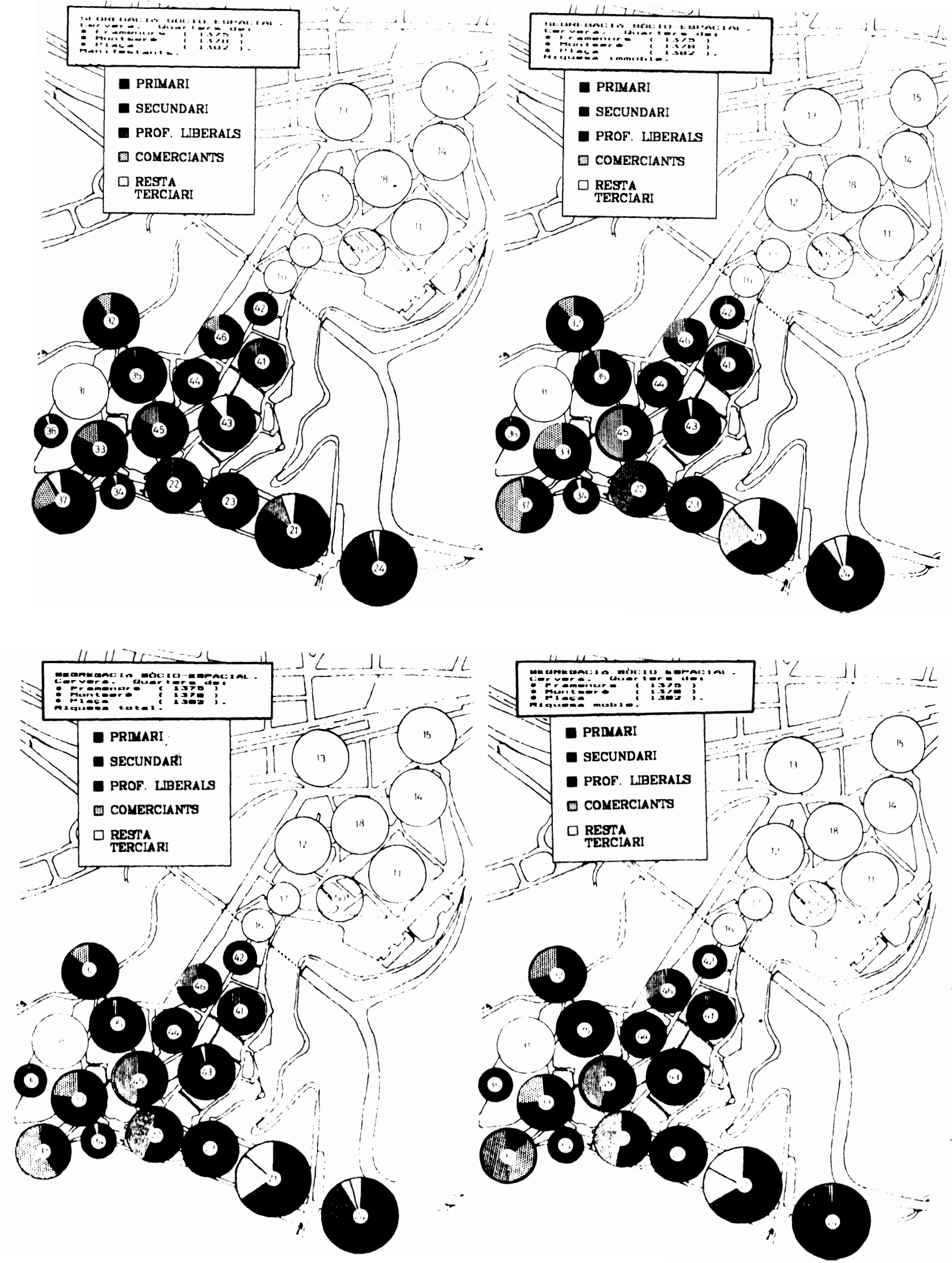

(c) Consejo Superior de Investigaciones Científicas http://estudiosmedievales.revistas.csic.es 
FIGURA 11.2. MIGRACIONS PRQFESSIONALS ENTRE CARRERS. Cervera, segle XIV (en manifestants)

\begin{tabular}{|c|c|c|c|c|c|c|c|c|}
\hline INPUT & OUTPUT & InoIvious & INPUT & OUTPUT & INoIVIOUS & INPUT & OUTPOT & InDIVIDUS \\
\hline $11(1340)$ & $22(1375)$ & $1 A, 1 C d$ & $21(1375)$ & $37(1378)$ & $7 A, 180$, & 43(1352) & $14(1369)$ & 18d \\
\hline $11(1340)$ & $24(1375)$ & 180 & ICd & & & $43(1352)$ & $23(1375)$ & IA \\
\hline $11(1340)$ & $31(1366)$ & ICd & $21(1375)$ & $44(1382)$ & $1 A$. & $43(1352)$ & $44(1366)$ & in \\
\hline $11(1340)$ & $33(1366)$ & ICa, ICC & $22(1375)$ & $36(1378)$ & ICl & $43(1366)$ & $11(1369)$ & ICd \\
\hline $11(1340)$ & $41(1382)$ & $1 A, 186$ & $22(1375)$ & $45(1382)$ & 180,286 & $43(1366)$ & 42(1302) & $2 \Lambda$ \\
\hline $11(1340)$ & $41(1382)$ & 180 & $24(1375)$ & $35(1378)$ & 186 & $43(1366)$ & 40(1382) & $3 A, 186$ \\
\hline $11(1340)$ & $44(1352)$ & lcd & $24(1375)$ & $36(1378)$ & $18 A, 282$, & $44(1352)$ & $22(1375)$ & IA \\
\hline $11(1340)$ & $46(1352)$ & 180 & 28b, ICd & & & $44(1352)$ & $24(1375)$ & $1 A, 1 C_{2}$ \\
\hline $11(1340)$ & $46(1382)$ & $1 A$ & $24(1375)$ & $37(1378)$ & 11 & $44(1352)$ & $33(1366)$ & IC2 \\
\hline $11(1369)$ & $38(1378)$ & $1 A$ & $24(1375)$ & $48(1382)$ & $18 \mathrm{~A}$ & $44(1352)$ & $35(1378)$ & IA \\
\hline $11(1369)$ & $37(1378)$ & icd & $31(1368)$ & $21(1375)$ & 5A, 181, & $44(1352)$ & $36(1378)$ & 186 \\
\hline $11(1369)$ & 42(1382) & 186 & ICd & & & $44(1352)$ & 45(1366) & $4 A, 1 B d$, \\
\hline $11(1369)$ & $48(1382)$ & 182 & $31(1368)$ & $24(1375)$ & 186 & $3 C_{2}, 3 \mathrm{Cd}$ & & \\
\hline $12(1340)$ & $11(1369)$ & $1 A$ & $31(1386)$ & $34(1378)$ & $3 A, 3 B d$ & $44(1352)$ & $45(1382)$ & ICd \\
\hline $12(1340)$ & $14(1369)$ & $18 \mathrm{~B}$ & 3111368 & & $37(1378)$ & $44(1352)$ & 48(1386) & IA \\
\hline $12(1340)$ & $35(1378)$ & 18d & $1 A, 1 B, 1 C$ & $0,1 C d, 1 C \theta$ & & $44(1368)$ & $48(1382)$ & ICa, ICd \\
\hline $12(1340)$ & $41(1352)$ & $1 A$ & $31(1366)$ & $48(1382)$ & ICO & 45(1352) & $35(1378)$ & $1 A$ \\
\hline $12(1340)$ & 43(1352) & 14 & $32(1366)$ & $21(1375)$ & 14 & $45(1352)$ & $48(1366)$ & $11 \mathrm{~A}, 1 \mathrm{Be}$ \\
\hline $12(1340)$ & 46(1382) & 14 & $32(1366)$ & $37(1378)$ & $1 A$ & $45(1386)$ & $35(1378)$ & $1 A$ \\
\hline $12(1369)$ & $24(1375)$ & $1 A$ & $33(1366)$ & $36(1378)$ & $2 A, 1 C 2$ & $45(1368)$ & $37(1378)$ & IA \\
\hline $12(1369)$ & $35(1378)$ & 180 & $33(1378)$ & $48(1382)$ & $1 A$ & $46(1352)$ & $11(1369)$ & 186 \\
\hline $12(1369)$ & $48(1382)$ & ICd & $34(1378)$ & $43(1382)$ & 11 & $48(1352)$ & $12(1369)$ & $1 B_{2}$ \\
\hline $13(1340)$ & 46(1366) & ICd & $35(1378)$ & 45(1382) & $1 A$ & 40(1352) & $32(1366)$ & ICd \\
\hline $14(1340)$ & $11(1369)$ & $1 A$ & $35(1378)$ & $46(1382)$ & $1 A$ & 46(1352) & $41(1382)$ & IC 1 \\
\hline $14(1340)$ & $12(1369)$ & ICd & $36(1368)$ & $12(1369)$ & $1 A$ & 48(1352) & $43(1366)$ & 180 \\
\hline $14(1340)$ & $16(1369)$ & $1 A, 182$ & $36(1366)$ & $22(1375)$ & ICd & 46(1366) & $24(1375)$ & $1 A$ \\
\hline $14(1340)$ & $21(1375)$ & 11 & $38(1386)$ & $36(1378)$ & $2 A$ & 48(1366) & $33(1378)$ & $1 A, 1 C d$ \\
\hline $14(1340)$ & $36(1366)$ & 180 & $36(1378)$ & 46(1382) & $2 A, 180$, & $48(1366)$ & $45(1382)$ & 186 \\
\hline $14(1340)$ & $41(1352)$ & $18 d$ & 186 & & & & & \\
\hline $14(1340)$ & 42(1352) & $1 A, 18 b$ & $37(1378)$ & $44(1382)$ & ICO & & & \\
\hline $14(1340)$ & $45(1366)$ & ICd & $41(1352)$ & $12(1369)$ & IA & & & \\
\hline $14(1340)$ & $46(1366)$ & 181,186 & $41(1352)$ & $14(1369)$ & $1 A$ & & & \\
\hline $14(1340)$ & $46(1382)$ & $1 A$ & $41(1366)$ & $14(1369)$ & $1 A$ & & & \\
\hline $14(1369)$ & $22(1375)$ & 11 & $41(1366)$ & $21(1375)$ & ICd & & & \\
\hline $14(1369)$ & $43(1382)$ & ICa & $41(1366)$ & $32(1378)$ & ICd & & & \\
\hline $15(1340)$ & $11(1369)$ & $1 A, I C C$, & $41(1366)$ & 12(1382) & IA & & & \\
\hline ICf & & & $42(1352)$ & $24(1375)$ & $18 b$ & & & \\
\hline $15(1340)$ & $37(1378)$ & $1 A$ & $42(1352)$ & $33(1378)$ & IA & & & \\
\hline $15(1340)$ & $44(1352)$ & $186,1 C 0$ & 12(1352) & $35(1378)$ & 286 & & & \\
\hline $15(1340)$ & $45(1352)$ & 11 & 12(1352) & $11(1366)$ & $2 A, 1 C d$ & & & \\
\hline $15(1340)$ & $48(1352)$ & ICd & $42(1352)$ & $43(1366)$ & $3 A, \quad 1 C C$, & & & \\
\hline $15(1340)$ & $48(1382)$ & $1 A$ & ICd & & & & & \\
\hline $16(1369)$ & $22(1375)$ & $1 A$ & 42(1352) & $45(1368)$ & ICa & & & \\
\hline $21(1375)$ & $35(1378)$ & $18 a, 1 B e$ & 43(1352) & $12(1369)$ & ICo & & & \\
\hline
\end{tabular}

1 A la columna dels inputs assenyalem el carrer d'origen, indicat en forma de número (veure la llista de llegendes abreviatures) amb $l$ 'any d'identificacio entre parentesi. A continuacio, en outputs, el carrer de desti $i$ ' any que ho vam documentar; en individus, la xifra assenyala la quantitat d'ells i les lletres la seva adscripcio professional. Amb aquesta informacio podem coneixer on i quan vivia un individu identificat professionalment $i$ on va anar a viure després d'uns anyo. 
FIGURA 12.2.-

ESTRUCTURA PROFESSIONAL PER QUARTERS

(en riquesa absoluta i número de manifestants).

\begin{tabular}{|c|c|c|c|c|c|c|c|c|c|c|c|c|c|c|c|c|}
\hline \multirow{3}{*}{$\frac{\text { ouner }}{\text { uns }}$} & \multicolumn{4}{|c|}{ CP oOA } & \multicolumn{6}{|l|}{ puss. } & \multicolumn{4}{|c|}{ Dorse } & \multirow{2}{*}{\multicolumn{2}{|c|}{$\frac{\text { PRVOST }}{13 \%}$}} \\
\hline & \multicolumn{2}{|l|}{130} & \multicolumn{2}{|l|}{130} & \multicolumn{2}{|l|}{130} & \multicolumn{2}{|l|}{12} & \multicolumn{2}{|l|}{132} & \multicolumn{2}{|l|}{130} & \multicolumn{2}{|l|}{$13 \pi$} & & \\
\hline & IOSAL & Do & IOTK & $n$ & Pork & $\infty$ & TOTAR & $\infty$ & ronaL & $\infty$ & TOTAL & 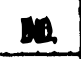 & TorN & $\boldsymbol{w}$ & TOTML & 80. \\
\hline mon & & & & & & & & & 200 & 1 & & & & & & \\
\hline Lurete & & & 491 & 2 & & & 100 & 1 & $\omega$ & 2 & $\omega$ & 3 & 0 & 1 & 400 & 1 \\
\hline 1. AMESA & 0 & & on & 2 & 0 & & 100 & 1 & $3 \sqrt[30]{5}$ & 3 & $\infty$ & 3 & 0 & 1 & an & 1 \\
\hline Araujuctor & & & & & & & $2 n$ & 1 & & & & & & & & \\
\hline Nevier & & & & & 200 & 1 & & & & & & & & & & \\
\hline$m$ & & & & & & & & & & & & & & & 3 & 3 \\
\hline Bn & & & 1000 & 1 & & & & & & & & & & & & \\
\hline man & & & $m$ & 1 & & & & & 13000 & 2 & & & & & & \\
\hline Bot & & & $\infty$ & 1 & & & & & & & & & 1917 & & & \\
\hline תחס & 4TR & 2 & & & & & & & & & & & & & & \\
\hline bur & 150 & 1 & & & & & & & & & & & & 1 & & \\
\hline aiders & 200 & 1 & & & & & & & & & & & & & & \\
\hline 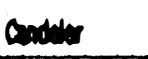 & & & & & & & 010 & 1 & $\sin$ & 1 & & & & & & \\
\hline order & & & 5000 & 1 & & & & & 270 & 1 & & & & & & \\
\hline ous & 150 & 1 & & & & & & & & & & & & & $\sin$ & \\
\hline coiretion & & & & & & & & & 1000 & 1 & & & & & & 2 \\
\hline Drem & & & & & & & 2000 & 2 & & & & & & & & \\
\hline Exprar & & & & & & & & & ser & 1 & 200 & & 258 & & 306 & \\
\hline Forter & 500 & 1 & 2000 & 1 & & & & & & & & 1 & & 1 & & 2 \\
\hline Findor & & & 300 & 1 & & & & & 274 & 1 & & & & & & \\
\hline formor & 240 & 1 & & & 1140 & 2 & 200 & 1 & & & & & $m$ & 1 & & \\
\hline Fremor & & & & & 10 & 1 & 116 & 1 & & & & & & & & \\
\hline fonter & 610 & 3 & $\infty$ & 3 & & & & & $3 B$ & 1 & 500 & 2 & 597 & 1 & 50 & 1 \\
\hline aviner & 1315 & 1 & 1500 & 1 & & & & & & & & & & & & \\
\hline Aping & & & 153 & 1 & & & & & 3010 & 2 & & & & & & \\
\hline Invor & & & & & no & 1 & 100 & 1 & & & 200 & 2 & 100 & 1 & 25 & 2 \\
\hline Lent & $\infty$ & 1 & & & & & & & & & & & & & & \\
\hline w & 2010 & 1 & & & & & 1000 & 1 & & & & & & & & \\
\hline mant & & & & & & & red & 1 & 1100 & 1 & $m$ & 1 & & & & \\
\hline וt & & & & 1 & & & & & & & 10 & 1 & & & & \\
\hline كستس & 1100 & 1 & $m$ & & & & & & & & & & & & & \\
\hline 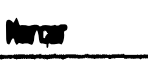 & & & & & & & 30 & 1 & 3 & 3 & & & wos & 1 & & \\
\hline Aren & T20 & 1 & & & & & & & $\operatorname{mon}$ & 1 & 100 & 1 & 3 & 1 & $\infty$ & 3 \\
\hline תוn & & & & & 100 & 1 & & & & & & & 500 & 1 & & \\
\hline now & 120 & 1 & 201 & 1 & 20 & 3 & 49 & 3 & tors & 2 & & & & & 10 & 1 \\
\hline Antror (c) $\mathrm{C}$ & Dnsejo S & perior & de Inve & igacio & hes Cient & ficas & $2 \pi 0$ & 1 & & & http://es & udiosm & edievale & s.revis & tas.csic & es \\
\hline How Recc & nqwamie & of.0 & ternac & nal (C & $\sqrt{\text { Crion } 4.0}$ & $\sqrt{2}$ & & & & & $m=1$ & 2 & 210 & 3 & KOS & 1 \\
\hline
\end{tabular}


IGURA 12.2.-

:STRUCTURA PROFESSIONAL PER QUARTERS

en riquesa absoluta i númeno de manifestants).

\begin{tabular}{|c|c|c|c|c|c|c|c|c|c|c|c|c|c|c|c|c|}
\hline \multirow{3}{*}{ MNS } & \multicolumn{4}{|c|}{ CAP ODaA } & \multicolumn{6}{|l|}{ puse } & \multicolumn{4}{|c|}{ WOISES } & \multirow{2}{*}{\multicolumn{2}{|c|}{ Ambas }} \\
\hline & \multicolumn{2}{|l|}{130} & \multicolumn{2}{|l|}{130} & \multicolumn{2}{|l|}{1302} & \multicolumn{2}{|l|}{130} & \multicolumn{2}{|l|}{132} & \multicolumn{2}{|l|}{18} & \multicolumn{2}{|l|}{$12 m$} & & \\
\hline & TOTAL & Do & TOTM & $n$ & DOHL & 0 & TOTA & Do & TOTL & $D$ & sorAl & $m$ & Tora & $D$ & TOTAL & 100 \\
\hline horet & & & & & 550 & 2 & & & & & & & & & & \\
\hline 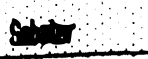 & $\infty$ & 1 & 675 & 3 & 10000 & 8 & 20274 & 1 & 30008 & 1 & .616 & 3 & 10074 & 9 & 20001 & 9 \\
\hline ant & & & 170 & 2 & 8130 & 1 & $\infty$ & 4 & 014 & 3 & 6036 & 2 & 1520 & 1 & 1412 & 5 \\
\hline ans & & 1 & & & & & & & & & & & & & & \\
\hline$s$ & & & $\infty$ & 1 & & & & & & & & & & & & \\
\hline resto & 200 & 3 & nom & 8 & 3120 & 2 & 1500 & 1 & wre & 3 & & & $s 00$ & 1 & mes & 8 \\
\hline rots & & & 540 & 1 & 5 & 1 & & & & & & & & & & \\
\hline 2 AnISONIS & $M 1$ & 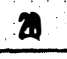 & nse & 2 & 200 & 31 & 1260 & $\mathbf{4}$ & retrou & 38 & 2 & 15 & 52130 & 3 & 8945 & 37 \\
\hline $\mathrm{Nat}$ & 300 & 1 & & & $\pi \times s$ & 5 & 1531Q & 1 & $\mathrm{Mrem}$ & 1 & 500 & 2 & 90 & 1 & $4 R$ & 1 \\
\hline Buts: & & & 1500 & 1 & 2100 & 1 & & & 5070 & 3 & & & & & & \\
\hline Aney & & & $3 \pi 0$ & 1 & & & & & & & & & & & & \\
\hline Enth & & & & & & & & & & & & & & & $\omega T$ & 1 \\
\hline$f(x)$ & 5006 & 1 & & & & & & & & & & & & & & \\
\hline ments & 46 & 1 & 2000 & 1 & & & & & 20.6 & 2 & 747 & 1 & 50 & 1 & $\sin$ & 1 \\
\hline bols & & & & & & & 516 & 1 & & & & & & & & \\
\hline more & & & & & & & 50 & 1 & 305 & 1 & & & & & 13700 & 1 \\
\hline Nori & 11000 & 4 & 53515 & 8 & oress & 1 & sons & 9 & 212873 & 13 & 118001 & 11 & 1000 & 3 & & \\
\hline $\begin{array}{l}\text { prowers } \\
\text { to ints }\end{array}$ & & & & & & & & & & & & & & & $2 x$ & 1 \\
\hline $\mathrm{sen}$ & 200 & 1 & 2400 & 3 & 2010 & 1 & 8714 & 1 & $\mathbf{1 1 2 1 5}$ & 4 & $\infty$ & 1 & 200 & 2 & & \\
\hline 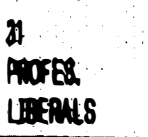 & Dוn & 8 & sed & 14 & Mros & $D$ & 3406 & 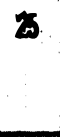 & $3 n(5)$ & $x$ & Ising & 15 & BDA & 1 & MTS & 5 \\
\hline
\end{tabular}




\begin{tabular}{|c|c|c|c|c|c|c|c|c|c|c|c|c|c|c|c|c|}
\hline \multirow{3}{*}{$\begin{array}{l}\text { OUARTER } \\
\text { ANS } \\
\text { Professtors } \\
\end{array}$} & \multicolumn{4}{|c|}{ AP Conel } & \multicolumn{6}{|l|}{ Puss } & \multicolumn{4}{|c|}{ DUTSER } & \multirow{2}{*}{\multicolumn{2}{|c|}{ forroms }} \\
\hline & \multicolumn{2}{|l|}{130} & \multicolumn{2}{|l|}{130} & \multicolumn{2}{|l|}{130} & \multicolumn{2}{|l|}{139} & \multicolumn{2}{|l|}{130} & \multicolumn{2}{|l|}{13} & \multicolumn{2}{|l|}{1370} & & \\
\hline & TOTAL & no. & TOTAL & Do. & SOALL & $\infty$ & TOTAL & 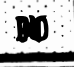 & IOTL & $D$ & IOHAL & $\infty$ & tora & $D$ & TOTL & $n$ \\
\hline Domant: & & & & & & & 300 & 1 & & & & & & & & \\
\hline Erero & & & 800 & 1 & & & & & & & & & & & & \\
\hline rots & & & & & & & & & & & & & & & 2000 & 1 \\
\hline 32 ESEIEST & 0 & & 800 & 1 & 0 & & 300 & 1 & $\theta$ & & 0 & & 0 & & $2 \pi 00$ & 1 \\
\hline Ones & $\infty$ & 1 & & & & & & & & & 3700 & & & & & \\
\hline matprax & & & & & 10 & 1 & 50 & 1 & & & & 2 & 1300 & 2 & & \\
\hline andr & & & 1200 & 1 & & & & & & & & & & & & \\
\hline sing & 12 & 3 & & & 3200 & 1 & & & & & & & & & & \\
\hline 33 noncenl. & 190 & 4 & 120 & 1 & $3=0$ & 2 & $5 \pi$ & 1 & 0 & & 300 & 2 & 150 & 2 & 0 & \\
\hline antion & 120 & 2 & & & in & 1 & 100 & 2 & & & 5 & 3 & 10001 & 1 & & \\
\hline connos & & & & & 700 & 3 & 200 & 1 & 907 & 2 & & & 50 & 3 & 3915 & 1 \\
\hline Encie & & & 3710 & 1 & 1150 & 1 & & & 200 & 1 & & & & & & \\
\hline moner & Q201 & 11 & 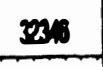 & 8 & 212001 & 10 & 2000 & 17 & 2000 & 20 & 117370 & 8 & ans & 11 & 10000 & $n$ \\
\hline $3 x \cos x \in$ & Bun & 13 & 300 & 2 & $\operatorname{man}$ & 2 & $2=4$ & 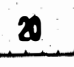 & 30037 & 2 & Lea & II & D/R & 18 & $100 \mathrm{~s}$ & 11 \\
\hline 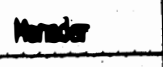 & & & & & & & & & & & $\infty$ & 1 & 710 & 1 & & \\
\hline Nonners & & & & & & & & & & & $\pi$ & 1 & 1700 & 3 & & \\
\hline Aing & & & 1310 & 1 & & & & & & & & & & & & \\
\hline $\begin{array}{l}3 \\
\text { Inuspord }\end{array}$ & 0 & & 1310 & 1 & 0 & & 0 & & 0 & & $\operatorname{lno}$ & 2 & $2 n$ & 4 & 0 & \\
\hline oncles & & & 500 & 1 & 1800 & 1 & & & & & & & 150 & 1 & $\infty$ & 1 \\
\hline $\begin{array}{l}\text { Querit in } \\
\text { Bratome }\end{array}$ & & & & & & & 3970 & & & & & & & & & \\
\hline Donolly & & & & & & & & 1 & 50 & 1 & & & & & & \\
\hline Smyor & 1000 & 1 & 2707 & 2 & & & 1000 & 2 & nesos & 1 & & & & & & \\
\hline x. feoons & 1000 & 1 & 300 & 3 & 120 & 1 & 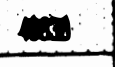 & 3 & 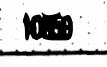 & 2 & 0 & & $B$ & 1 & 0 & 1 \\
\hline Enemteres & 000 & 1 & & & & & & & & & & & & & & \\
\hline connes & & & $\infty$ & 3 & & & & & & & & & & & & \\
\hline Venter & 1317 & 10 & & & 10 & 1 & & & & & & & & 1 & & \\
\hline Inten & $2 \pi m$ & $\mathbf{z} 1$ & 501307 & 15 & 51113 & 100 & 51800 & 111 & $31 \times 2$ & $\infty$ & 20000 & 100 & 250011 & 150 & 20015 & 10 \\
\hline $\begin{array}{l}\text { LSBDEF } \\
\text { PROFESSY }\end{array}$ & 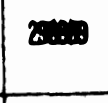 & $m$ & $\infty$ & 170 & sn110 & 10 & 51200 & 111 & meses & $\boldsymbol{c}$ & 20 & 16 & 20011 & $15 t$ & 200015 & 10 \\
\hline TOTAL & 42010 & 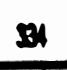 & $\infty$ & 20 & sons & 2 & rang & 10 & $117 \mathrm{~nm}$ & 10 & mex & 190 & SOTR1 & 210 & $\sin \theta$ & 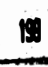 \\
\hline
\end{tabular}



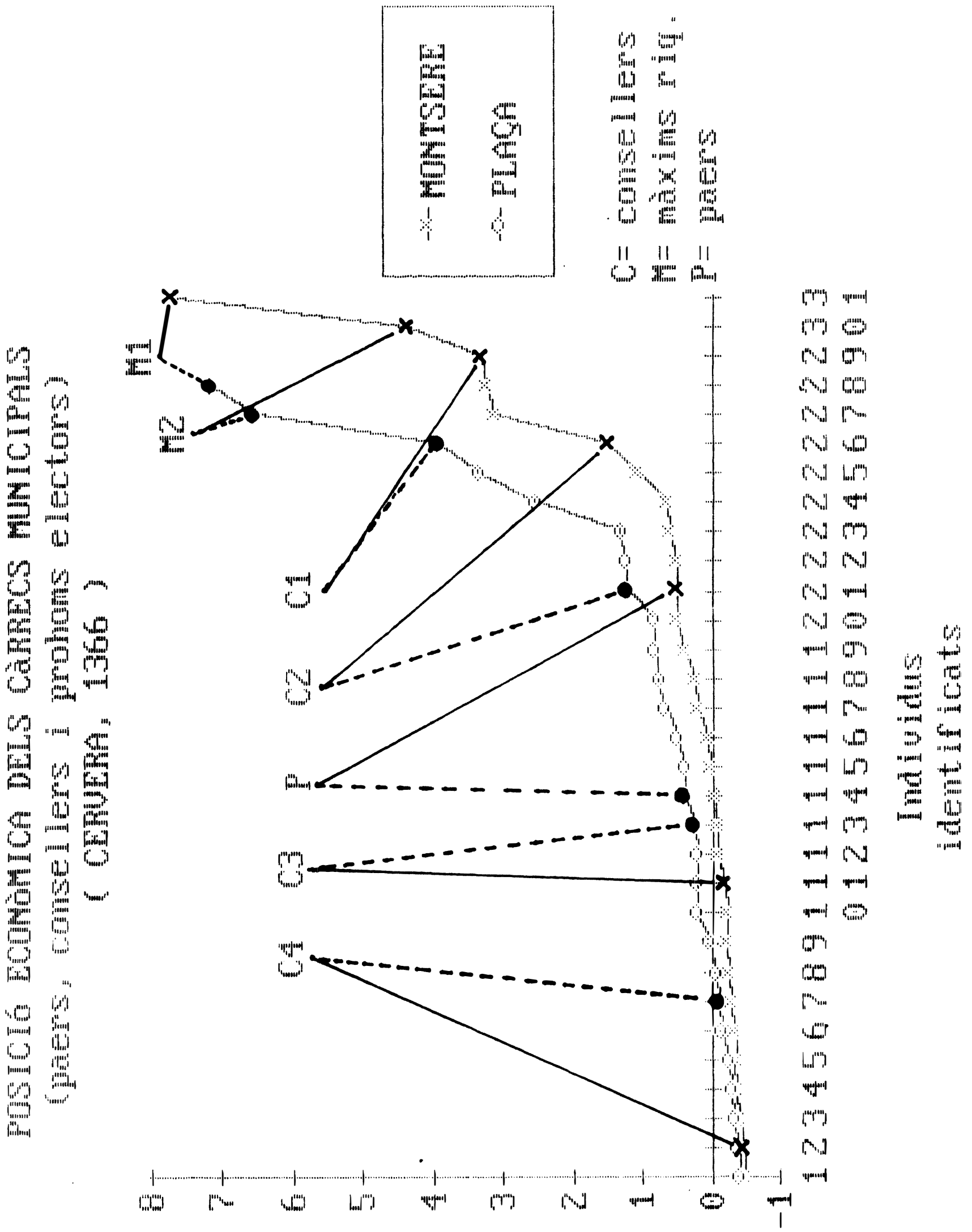

0

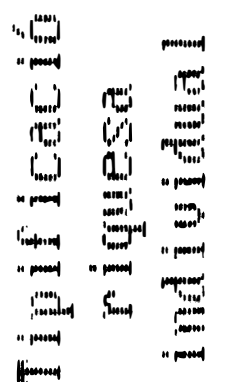

(c) Consejo Superior de Investigaciones Científicas 

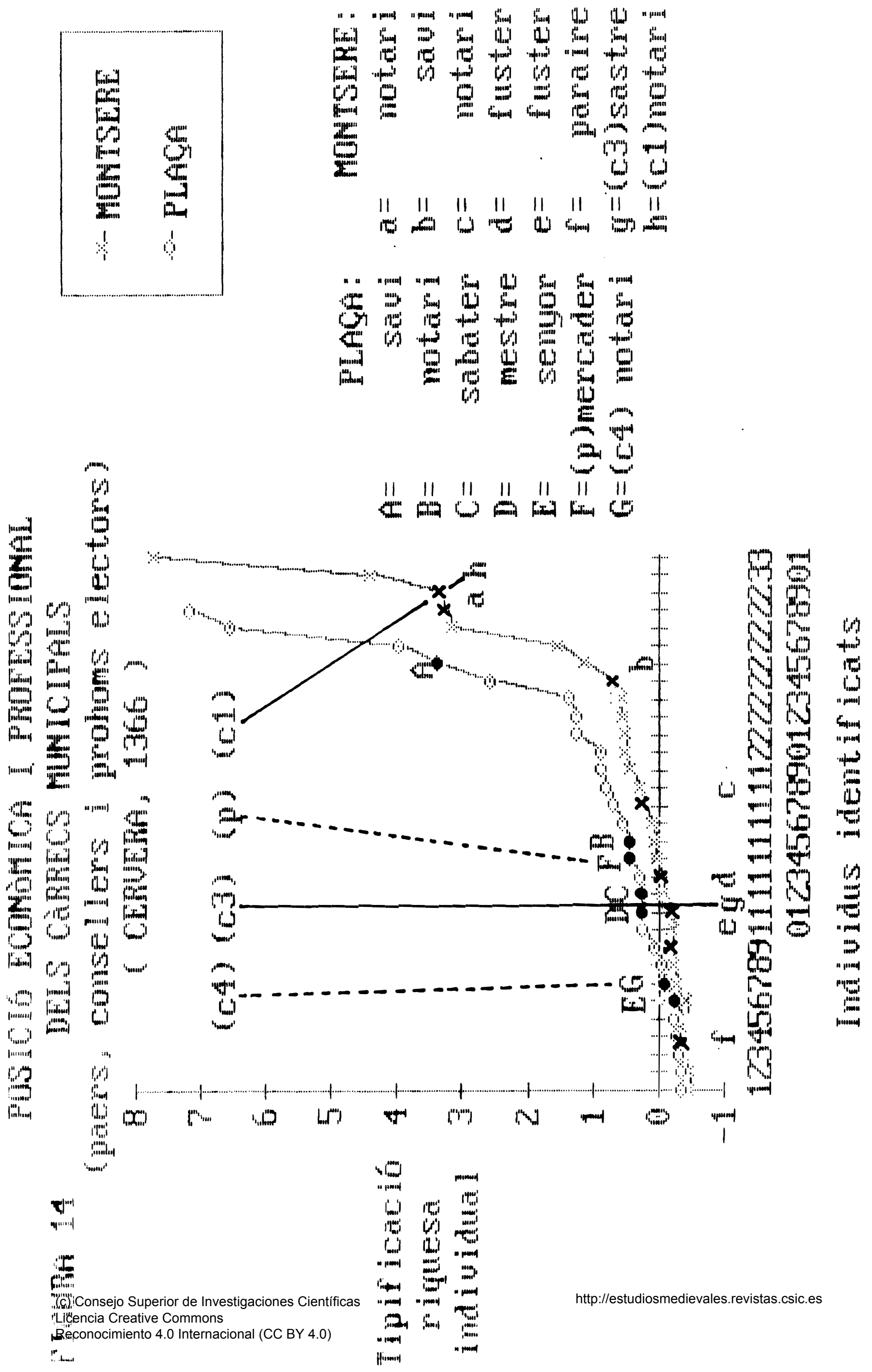